\title{
nombalina
}

(8)

\section{A fraude académica no Ensino Superior em Portugal: um estudo sobre a ética dos alunos portugueses}

Autor(es): $\quad$ Almeida, Filipe; Seixas, Ana; Gama, Paulo; Peixoto, Paulo

Publicado por: Imprensa da Universidade de Coimbra

URL

persistente: URI:http://hdl.handle.net/10316.2/38480

DOI: $\quad$ DOI:http://dx.doi.org/10.14195/978-989-26-1070-2

Accessed : $\quad$ 19-May-2017 17:51:36

A navegação consulta e descarregamento dos títulos inseridos nas Bibliotecas Digitais UC Digitalis, UC Pombalina e UC Impactum, pressupõem a aceitação plena e sem reservas dos Termos e Condições de Uso destas Bibliotecas Digitais, disponíveis em https://digitalis.uc.pt/pt-pt/termos.

Conforme exposto nos referidos Termos e Condições de Uso, o descarregamento de títulos de acesso restrito requer uma licença válida de autorização devendo o utilizador aceder ao(s) documento(s) a partir de um endereço de IP da instituição detentora da supramencionada licença.

Ao utilizador é apenas permitido o descarregamento para uso pessoal, pelo que o emprego do(s) título(s) descarregado(s) para outro fim, designadamente comercial, carece de autorização do respetivo autor ou editor da obra.

Na medida em que todas as obras da UC Digitalis se encontram protegidas pelo Código do Direito de Autor e Direitos Conexos e demais legislação aplicável, toda a cópia, parcial ou total, deste documento, nos casos em que é legalmente admitida, deverá conter ou fazer-se acompanhar por este aviso. 


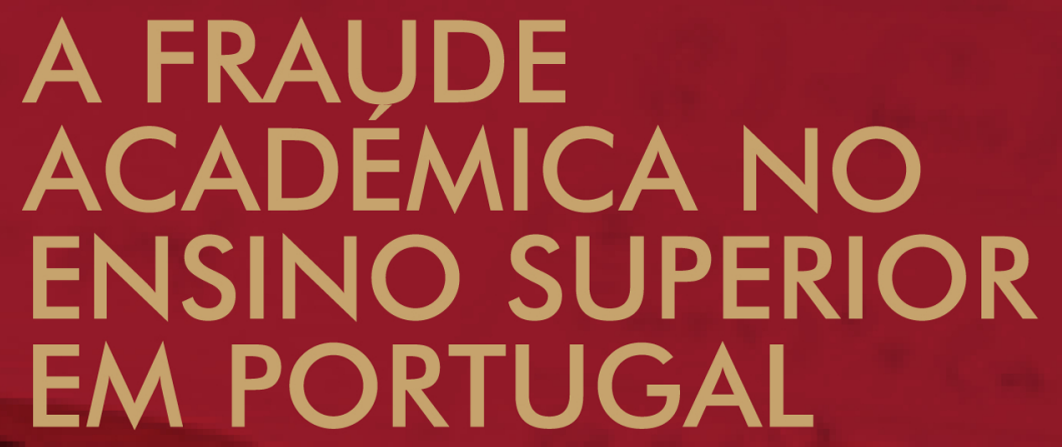

UM ESTUDO SOBRE A ÉTICA DOS ALUNOS PORTUGUESES

FILIPE ALMEIDA

ANA SEIXAS

PAULO GAMA

PAULO PEIXOTO
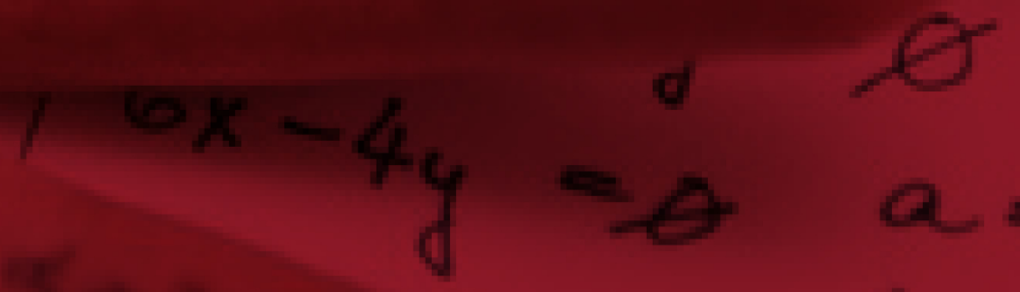

IMPRENSA DA UNIVERSIDADE DE COIMBRA

COIMBRA UNIVERSITY PRESS 


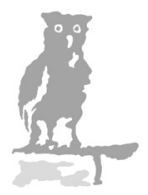

$\begin{array}{lllllllllllll}\text { I } & \mathrm{N} & \mathrm{V} & \mathrm{E} & \mathrm{S} & \mathrm{T} & \mathrm{I} & \mathrm{G} & \mathrm{A} & C & \AA & \end{array}$<smiles>C[C@H]1[C@H](C)[C@H](C)[C@H]1C</smiles> 


\section{Coordenação editorial}

Imprensa da Universidade de Coimbra

Email: imprensa@uc.pt

URL: http://www.uc.pt/imprensa_uc

Vendas online: http://livrariadaimprensa.uc.pt

\section{Concepção gráfica}

António Barros

\section{Infografia da Capa}

Carlos Costa

\section{Pré-Impressão}

Bookpaper

\section{Execução gráfica}

Simões \& Linhares, Lda

\section{ISBN}

978-989-26-1069-6

\section{ISBN DIGITAL}

978-989-26-1070-2

\section{DOI}

http://dx.doi.org/10.14195/978-989-26-1070-2

\section{Depósito legal}

$402287 / 15$

(C) Novembro 2015, Imprensa da Universidade de Coimbra. 


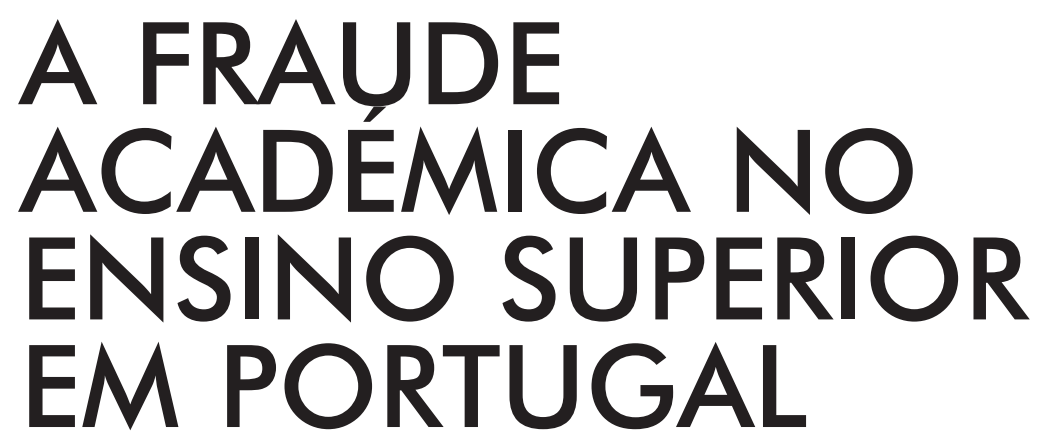

UM ESTUDO SOBRE A ÉTICA DOS ALUNOS PORTUGUESES

FILIPE ALMEIDA

ANA SEIXAS

PAULO GAMA

PAULO PEIXOTO

IMPRENSA DA UNIVERSIDADE DE COIMBRA

COIMBRA UNIVERSITY PRESS 
(Página deixada propositadamente em branco) 


\section{S U M Á R I O}

Introdução

Capítulo I - A fraude académica: conceito e tipologias

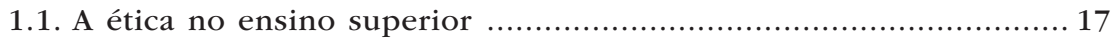

1.2. A fraude académica cometida por alunos .............................. 19

1.3. Um conceito e uma tipologia de fraude académica ................... 21

Capítulo II - A fraude académica cometida por alunos em Portugal

2.1. O estudo dos alunos em Portugal ....................................... 25

2.1.1. Objetivos do estudo ........................................... 25

2.1.2. Seleção da amostra de alunos ..................................... 26

2.1.3. O método de recolha de dados ...................................... 29

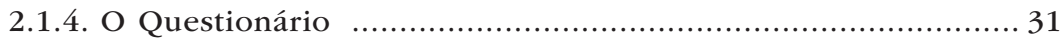

2.1.5. Descrição da amostra final ..................................... 34

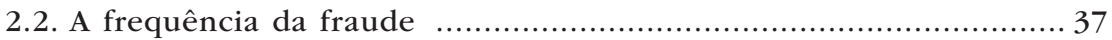

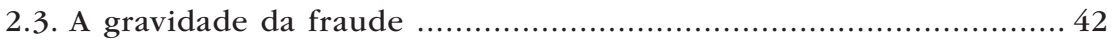

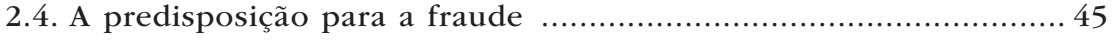

2.5. O Indicador de Predisposição para a Fraude (IPF) ….................. 53

2.6. O Indicador de Predisposição para a Denúncia (IPD) ................. 59

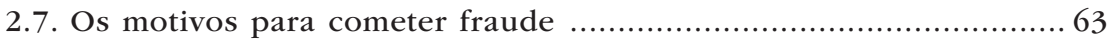




\section{Capítulo III - A tolerância dos professores}

3.1. O estudo dos professores em Portugal

3.1.1. Objetivos do estudo 85

3.1.2. Seleção da amostra de professores ................................. 86

3.1.3. O método de recolha de dados .................................. 86

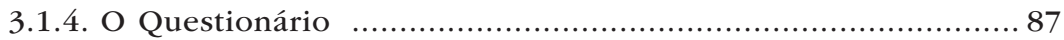

3.1.5. Descrição da amostra final ......................................... 88

3.2. A satisfação académica dos professores …............................... 89

3.3. A sensibilidade dos professores à fraude dos alunos ................ 93

3.4. A intolerância dos professores à fraude dos alunos ................... 97

3.5. A perceção dos professores sobre as práticas

de fraude dos alunos ...................................................... 101

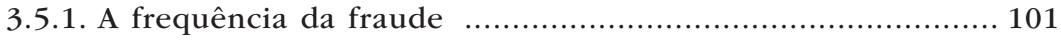

3.5.2. Os motivos da fraude ................................................. 105

3.5.3. Os inibidores da fraude .......................................... 110

3.6. A reação dos professores perante a fraude dos alunos .............. 115

3.7. Os inibidores da denúncia segundo os professores ................. 117

Capítulo IV - Resumo dos Resultados

4.1. Resumo dos Resultados Globais dos Alunos .......................... 125

4.2. Resumo dos Resultados dos Alunos por Área Científica ............. 128

4.2.1. Economia e Gestão .......................................... 128

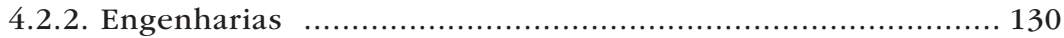

4.2.3. Medicina ........................................................ 132

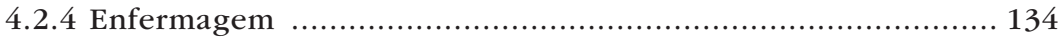


4.2.5. Educação …......................................................... 136

4.2.6. Direito ....................................................... 138

4.2.7. Ciências Sociais e Humanas ........................................... 140

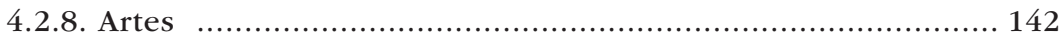

4.3. Resumo dos Resultados dos Professores ............................ 144

Capítulo V - Conclusões Principais ........................................ 149

Referências Bibliográficas ........................................... 157

ANEXO 1 - Questionários aos Alunos .................................. 161

ANEXO 2 - Questionário aos Professores ............................... 171

ANEXo 3 - Cursos Inquiridos na Amostra Final de Alunos ......... 179

ANEXO 4 - Resultados Estatísticos ................................... 183

Lista de Quadros

Quadro 1. Tipologia da Fraude Académica cometida por Alunos ........ 23

Quadro 2. Práticas de Fraude Académica analisadas ......................... 33

Quadro 3. Áreas Científicas, Cursos e número de Alunos .................. 36

Quadro 4. Inibidores da Denúncia da Fraude Académica pelos Docentes (opiniões dos docentes)

Lista de Tabelas

Tabela 1. Amostra inicial de alunos do ensino superior português a inquirir

Tabela 2. Amostra final de alunos do ensino superior

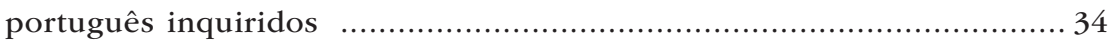

Tabela 3. Dados demográficos da amostra final ........................... 37

Tabela 4. Frequência de Fraude Académica por área científica ........... 39 
Tabela 5. Frequência das Práticas de Fraude Académica .................. 40

Tabela 6. Gravidade da Fraude Académica ................................... 43

Tabela 7. Predisposição para cometer Fraude Académica .................. 46

Tabela 8. Predisposição para cometer Fraude Académica

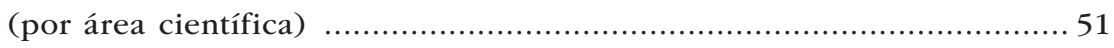

Tabela 9. Motivos para cometer Fraude Académica ........................6 63

Tabela 10. Inibidores da Fraude Académica ................................... 70

Tabela 11. Satisfação Académica dos Alunos .................................... 76

Tabela 12. Evolução da Perceção sobre a Frequência das Práticas de Fraude Académica (2011-2013) ............................... 77

Tabela 13. Evolução da Opinião sobre a Gravidade das Práticas de Fraude Académica (2011-2013) .............................. 79

Tabela 14. Evolução da Predisposição para cometer

Fraude Académica (2011-2013) ............................................... 80

Tabela 15. Evolução do IPF e do IPD (2011-2013) ............................ 81

Tabela 16. Evolução da Opinião sobre os Motivos

da Fraude Académica (2011-2013) ....................................... 82

Tabela 17. Evolução da Opinião sobre os Inibidores

da Fraude Académica (2011-2013) ........................................ 83

Tabela 18. Satisfação Académica dos Professores .......................... 90

Tabela 19. Satisfação Académica dos Docentes

(por subsistema de ensino) .................................................... 92

Tabela 20. Gravidade da Fraude Académica

(opinião dos docentes) ....................................................... 94

Tabela 21. Intolerância dos Professores à Fraude ............................ 98

Tabela 22. Frequência das Práticas de Fraude Académica

(perceção dos docentes) .................................................... 103

Tabela 23. Motivos para cometer Fraude Académica

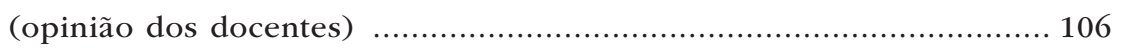

Tabela 24. Inibidores da Fraude Académica

(opinião dos docentes) ....................................................... 111

Tabela 25. Reação dos docentes perante a deteção

de Fraude Académica ............................................................... 116 
Tabela 26. Inibidores da Denúncia da Fraude Académica pelos Docentes

Lista de Gráficos

Gráfico 1. Predisposição para Apresentar o mesmo trabalbo em diferentes disciplinas (comparação por área científica)

Gráfico 2. Predisposição para Copiar respostas de um colega numa prova escrita (comparação por área científica)

Gráfico 3. Predisposição para Consultar materiais não

autorizados numa prova escrita (comparação por área científica)

Gráfico 4. Predisposição para Inventar dados num trabalbo

escrito (comparação por área científica)

Gráfico 5. Predisposição para Copiar trabalbo da Internet

(comparação por área científica) 50

Gráfico 6. Indicador de Predisposição para Fraude (IPF) ..................56

Gráfico 7. Predisposição para a Fraude Ativa e a Fraude Passiva .......58

Gráfico 8. Indicador de Predisposição para a Denúncia (IPF)

Gráfico 9. Motivos para cometer Fraude Académica

(por área científica)

Gráfico 10. Inibidores da Fraude Académica (por área científica) ..... 72

Gráfico 11. Perceção sobre Gravidade da Fraude Académica (alunos e docentes)

Gráfico 12. Perceção sobre Frequência da Fraude Académica

(alunos e docentes)

Gráfico 13. Perceção sobre Motivos da Fraude Académica

(alunos e docentes) 108

Gráfico 14. Perceção sobre Inibidores da Fraude Académica

(alunos e docentes) 
(Página deixada propositadamente em branco) 


\section{N T R O D U Ç Ã O}

Este livro destina-se a apresentar e discutir os resultados de um estudo sobre a fraude académica cometida por alunos no ensino superior em Portugal realizado entre 2011 e 2014, no âmbito de um projeto de investigação conduzido por docentes da Universidade de Coimbra, no Centro de Estudos Sociais, e financiado pela Fundação para Ciência e a Tecnologia ${ }^{1}$. Apresenta os principais resultados alcançados no âmbito do projeto e é complementado por um segundo livro, escrito no mesmo âmbito desta obra sob o título "Fraude e plágio na universidade: a urgência de uma cultura de integridade para o ensino superior".

Embora a fraude académica possa ser praticada por alunos ou docentes, por funcionários administrativos ou pelas próprias instituições, optou-se por estudar apenas a fraude cometida por alunos, dada a importância que ela pode ter para entender e explicar a conduta e o sistema de valores dos profissionais qualificados que os alunos do ensino superior serão no futuro.

Apesar da aparente clareza do seu significado e do aparente consenso sobre a perversidade dos seus efeitos, a fraude académica é um fenómeno ainda insuficientemente compreendido. Estudos em todo o mundo sugerem que a fraude cometida por alunos tem

${ }^{1}$ Projeto "A ética dos alunos e a tolerância de professores e instituições perante a fraude académica no ensino superior" (PTDC/CPE-CED/115915/2009), financiado no âmbito do Programa Operacional Temático Factores de Competitividade (COMPETE) e comparticipado pelo Fundo Comunitário Europeu FEDER. 
incidências variáveis consoante a região e a cultura, embora revele tendências consistentes de crescimento e disseminação. Não se tratando de um comportamento novo, assume novas formas que são facilitadas pela inovação tecnológica, tendo-se tornado mais difícil de combater a partir do momento em que ocorre um aumento significativo de alunos a frequentar o ensino superior e também devido à diversificação das modalidades de ensino e de aprendizagem. A fraude, enquanto ato ou omissão consciente que visa intencionalmente simular um conhecimento ou uma competência, compromete a qualidade da avaliação e a utilidade do próprio ensino, contribuindo para degradar estruturas fundamentais da sociedade, como sejam a confiança recíproca e o conhecimento transmitido. É por isso importante estudá-la, compreendê-la e, tanto quanto possível, desenhar e implementar políticas integradas de combate às suas causas e de minimização dos seus efeitos.

A investigação sobre fraude académica é ainda escassa e pouco consensual, enfrentando desafios metodológicos que em geral dificultam a sua comparação e generalização. Um primeiro obstáculo é a própria ausência de uma conceção teórica consensual sobre fraude académica. As práticas fraudulentas são muitas vezes estudadas sem que sejam enquadradas por uma teoria mais vasta que explique por que são consideradas fraude e qual a relação que existe entre elas. Esta ausência de uma definição clara e de uma reflexão teórica consolidada sobre a fraude académica dificulta o entendimento do fenómeno e o diálogo entre os diversos investigadores. Um segundo obstáculo é a ausência de uma medida clara e abrangente de fraude académica, limitando-se muitos estudos a avaliar a frequência com que ocorrem ou poderão ocorrer determinadas práticas. Sem uma medida unificadora e coerente, os resultados dificilmente podem ser comparados e a investigação científica dificilmente agrega valor que permita a construção de um corpo consistente de conhecimento. Um terceiro obstáculo prende- 
-se com a baixa fiabilidade das respostas, dado que ao questionar os alunos sobre a sua conduta, poderá prevalecer a tendência para responderem com base no comportamento que consideram socialmente desejável e não com base naquele que efetivamente praticam, mesmo em inquéritos anónimos. Um último obstáculo, comum à maioria dos estudos de ciências sociais, diz respeito ao limitado potencial de generalização dos resultados, dada a dimensão pequena da amostra, em geral restrita a um contexto académico específico ou a uma área científica particular.

$O$ estudo que deu origem a este livro procurou minimizar cada um destes obstáculos. Primeiro, propõe-se uma conceção de fraude académica que inclui uma definição que clarifica o seu significado e as suas fronteiras e que inclui uma tipologia de fraude devidamente articulada, a partir da qual se identificam as práticas transgressoras. Segundo, apresenta um questionário de resposta fechada e uma medida agregada de predisposição para a fraude ou para a denúncia, combinando diversas práticas. Terceiro, avalia-se a predisposição dos alunos para cometerem fraude através de cenários com personagens fictícias, apresentando perguntas projetivas que evitam questionar diretamente qual a conduta do inquirido, diminuindo os constrangimentos morais que poderiam justificar uma resposta enviesada. E por fim, estudou-se uma amostra tão abrangente e representativa quanto possível, com os diferentes subsistemas de ensino superior e áreas científicas tendencialmente representadas na proporção do seu significado no contexto do ensino superior em Portugal.

Além da aplicação de um questionário que permitiu recolher 7.292 respostas válidas de alunos portugueses que estudam em 182 cursos de 101 instituições de ensino superior (incluindo Faculdades, Departamentos e Escolas) em Portugal, foi também aplicado dois anos depois um segundo questionário a 341 alunos que aceitaram ser novamente inquiridos para avaliar a evolução do seu pensa- 
mento e das suas perceções sobre a fraude académica. Assim, foi possível analisar também como se modificou a perceção dos alunos ao longo do seu percurso académico, observando desta forma o eventual efeito de uma experiência mais aprofundada no ensino superior.

Como complemento ao estudo sobre o pensamento dos alunos, foram inquiridos também os docentes do ensino superior em Portugal, reunindo respostas de 2.727 docentes de diversas áreas científicas e instituições, públicas e privadas. Efetivamente, a fraude cometida por alunos só poderá beneficiá-los se não for detetada ou se for ignorada por quem é responsável pela avaliação dos seus conhecimentos e competências. Por isso, o compromisso dos docentes na prevenção, vigilância, deteção, denúncia e punição da fraude é central no processo de combate à sua prática no ensino superior. Este questionário permitiu comparar as perceções de docentes com as que foram expressas pelos alunos no outro questionário, além de investigar aspetos particulares como a sensibilidade e intolerância dos docentes perante a fraude, a sua reação perante a fraude observada ou os motivos que inibem a sua denúncia.

Este livro está dividido em cinco capítulos. O Capítulo I apresenta uma breve discussão sobre a ética e a fraude no ensino superior, propondo um conceito e uma tipologia de fraude académica. No Capítulo II são apresentados e interpretados os resultados do estudo sobre a perceção dos alunos acerca da fraude académica em Portugal, incluindo análises comparativas entre oito grandes áreas científicas. No Capítulo III são apresentados e discutidos os resultados do estudo sobre as perceções dos docentes, incluindo algumas análises comparativas com as perceções e opiniões dos alunos. No Capítulo IV é apresentada uma sistematização dos resultados alcançados, com dados e breve análise de cada uma das oito áreas científicas estudadas no caso dos alunos. Por fim, no Capítulo V são sistematizadas algumas das conclusões principais dos estudos 
apresentados nos capítulos anteriores e lançadas pistas para futuras reflexões com base nas evidências e análises produzidas neste que é um dos mais amplos trabalhos de investigação realizados até à data sobre a fraude académica em Portugal. 
(Página deixada propositadamente em branco) 


\section{CAPÍTULO I \\ A FRAUDE ACADÉMICA: \\ CONCEITO E T I POLOGIAS}

\subsection{A ética no ensino superior}

A "ética" é uma palavra escorregadia que pode ser fonte de muitos equívocos e de mal entendidos nem sempre reversíveis. Dentro dela cabem muito significados que podem dar a ilusão do entendimento entre quem de facto discorda ou a ilusão do antagonismo entre quem de facto concorda. Mas, se a palavra "ética" pode gerar desacertos indesejáveis, já o conceito de "ética" é uma necessidade natural do ser humano, desde sempre confrontado com a angústia existencial de tentar distinguir o "bem" e o "mal", de julgar a "justiça" das suas escolhas e das dos outros, de encontrar um equilíbrio moral entre os seus interesses e os seus afetos, entre os seus deveres e as suas paixões.

Portanto, de forma simples, a ética pessoal refere-se ao julgamento que cada indivíduo faz sobre a moralidade das ações humanas e das intenções que lhes são subjacentes, a partir das suas conceções de "bem" e de "justiça". No contexto profissional, os padrões morais adotados serão, em grande medida, o resultado do cruzamento de influências provenientes da educação familiar, da instrução formal, das experiências de vida, da cultura nacional e organizacional de tolerância à fraude e até das exigências específicas de cada setor de atividade. No caso particular da ética no trabalho, a formação 
universitária pode desempenhar um papel decisivo na consolidação de um sistema de valores morais alinhado com um padrão ético exigente. Mas também pode estimular condutas vulneráveis à ação transgressora. Por isso, o debate sobre a ética dos alunos no ensino superior e sobre o contexto que a envolve revela-se essencial para compreender o papel da educação formal na estruturação da ética pessoal que antecede e que influenciará a sua conduta moral no contexto profissional futuro.

Mesmo aceitando que uma parte substancial dos conceitos pessoais de "bem" e de "mal" estão já consolidados quando o aluno inicia o seu percurso académico de nível superior, é razoável admitir que ainda existe abertura significativa para integrar no seu pensamento novos critérios de decisão sobre o que está "certo" e "errado" em determinado contexto profissional que ele ainda desconhece. A disponibilidade de um aluno universitário para amplificar, modificar e inibir o seu sistema de crenças é muito alta. Por isso a cultura da instituição onde estuda, as práticas de ensino utilizadas pelos professores, as ideias incentivadas e ignoradas são sinais fundamentais para a formação de uma ética pessoal e sua natural extensão ao contexto profissional.

Uma instituição de ensino, tal como qualquer outra organização, tem implícito nos seus regulamentos, nos seus procedimentos, nas suas ações e nas suas respostas um modelo ético. Em alguns casos ele está explícito numa carta de princípios ou num código de conduta, o que não significa necessariamente que seja mais do que um reflexo de intenções não praticadas. Mas existe sempre uma qualquer cultura ética institucional, relativamente coerente, mesmo que ela não emane de uma intenção consciente dos seus agentes. Um modelo ético é essencialmente um sistema de crenças que valoriza e desvaloriza condutas e escolhas humanas. E assim, pode resumir-se em dois grandes propósitos gerais: promover o "bem" e prevenir o "mal". A fraude académica cometida por alunos no ensino superior é precisamente um dos "males" que deve ser combatido e evitado. 


\subsection{A fraude académica cometida por alunos}

A fraude académica cometida por alunos é um problema de ordem institucional e social. Ela compromete a solidez de estruturas básicas da sociedade, tais como a confiança nas instituições e a confiança interpessoal. Entre outros determinantes culturais e até mesmo antropológicos, a incapacidade das instituições de ensino superior responderem eficazmente ao aumento do número de alunos que as frequentam pode estar na origem da tendência mundial para aumento das práticas de fraude. Esta massificação do acesso ao ensino superior não parece ter sido acompanhada por políticas públicas e institucionais adequadas à manutenção da qualidade do ensino e da aprendizagem.

Por um lado, devido à alteração do rácio professores/alunos, mas também a fenómenos como a semestralização e a mobilidade docente e discente, consolidam-se relações pedagógicas mais impessoais, deteriorando a reciprocidade do processo interativo no qual deve basear-se qualquer processo educativo. Este distanciamento descompromete os alunos perante o professor, tornando emocionalmente mais fácil ao aluno o engano, a dissimulação, o fingimento. Por outro lado, com mais alunos a estudar e um mercado de trabalho mais exíguo, aumenta a pressão competitiva entre eles, criando um sentimento de urgência e de ausência de alternativa de vida perante o fracasso académico.

Do ponto de vista dos professores, o desconhecimento individual dos alunos provocado, entre outros fatores, pelo aumento significativo da dimensão das turmas, pela multiplicação de unidades curriculares atribuídas aos docentes, pelo absentismo dos alunos às aulas, também impede um acompanhamento mais personalizado e um controlo mais eficaz da sua conduta. A esta incapacidade dos professores para acompanharem eficazmente e exercerem uma ação preventiva junto dos alunos, juntar-se-á também uma maior dispersão 
da sua atenção, dada a exigência do seu envolvimento em tarefas administrativas e a pressão crescente sobre a sua carreira docente, cujo progresso e valorização dependem cada vez mais do seu desempenho científico do que do seu empenho pedagógico.

As relações pedagógicas mais impessoais e o aumento da pressão competitiva entre os alunos, aliados ao acesso facilitado a novas tecnologias de informação e de comunicação, criam um contexto favorável ao florescimento da fraude académica. Os regulamentos disciplinares, enquanto instrumentos dissuasores e de punição da fraude, são insuficientes para criar uma cultura de intolerância à fraude. É necessário que eles façam parte de uma política institucional integrada de soluções e mecanismos de prevenção e de combate às práticas fraudulentas, tais como ações de esclarecimento, envolvimento dos professores no debate, respostas institucionais claras perante a fraude, uma vigilância eficaz, procedimentos céleres e comprometimento de todos os agentes no processo. A reputação institucional, elemento fundamental de atração de alunos e de obtenção de financiamento, pode também ser potencialmente muito afetada por uma imagem pública de facilitismo e de tolerância perante comportamentos socialmente indesejáveis de engano e de logro intencional do sistema de ensino por parte dos alunos.

A fraude académica cometida por alunos no ensino superior implica, geralmente, uma avaliação equivocada das suas competências, certificando conhecimentos que de facto eles não possuem. Validados pela instituição de ensino, estes alunos insuficientemente preparados comprometem o progresso coletivo por via da sua incompetência técnica e da sua predisposição para uma prática profissional fraudulenta (perante a organização, perante os colegas de trabalho ou perante o próprio Estado e a sociedade em geral). A tolerância e a vigilância insuficientes perante a fraude académica originam, assim, diversas ineficiências materiais e injustiças sociais. Por isso este tema vem sendo cada vez mais estudado e discutido nos meios 
académicos e na sociedade em geral, penetrando igualmente com crescente importância no discurso e na ação políticas.

\subsection{Um conceito e uma tipologia de fraude académica}

A ética académica de um aluno que frequenta um curso no ensino superior pode ser analisada através das suas práticas e das suas escolhas morais. Entre estas, distinguem-se os comportamentos moralmente desejáveis (por exemplo, a transparência relacional, o respeito institucional, a cooperação interpares, o cumprimento de compromissos e a defesa do interesse coletivo) dos comportamentos moralmente condenáveis (por exemplo, a agressividade, a passividade ou o isolamento injustificados, a fraude administrativa ou a fraude académica). A fraude académica constitui, portanto, uma das dimensões da relação ética dos alunos com o contexto institucional e educacional onde estão integrados. Trata-se de um comportamento indesejável que compromete a justiça do processo avaliativo, a eficácia do processo educativo e a confiança nas instituições que o administram.

Embora exista uma concordância estável sobre os efeitos nocivos da fraude académica, não existe, no entanto, um consenso claro sobre as suas fronteiras. A ausência de um conceito agregador que permita delimitar com clareza o que constitui fraude académica é uma das principais dificuldades que enfrenta quem pretende estudar e entender este fenómeno. É por isso comum a realização de estudos sobre fraude com abordagens muito diversas, restringidos apenas a uma ou a algumas das suas dimensões práticas, o que dificulta a análise comparada e a compreensão mais alargada do fenómeno. A clarificação do seu significado é portanto essencial para entender os desdobramentos e ramificações da fraude académica em contexto escolar. 
A fraude académica do aluno do ensino superior tem, em si mesma, uma implicação moral delimitada pela honestidade perante a instituição, pela lealdade perante os colegas, pela transparência perante os professores e pela dignidade individual perante si próprio. Assim, propõe-se definir a fraude académica em termos tão abrangentes quanto possível, nos seguintes termos:

Fraude Académica é todo o ato ou omissão consciente que possa comprometer a justiça na avaliação dos desempenhos, competências e conhecimentos dos alunos.

Desta forma, a fraude académica pode ser cometida pelos alunos, pelos docentes, por funcionários administrativos das instituições de ensino, por agentes externos ou pela própria instituição no âmbito da sua política pedagógica. Adotando a justiça da avaliação como critério central de julgamento da fraude, este conceito exclui naturalmente a negligência dos alunos e dos professores, remetendo-as para outro domínio de análise moral. É verdade que o desinteresse de um aluno em aprender e a ignorância ou enviesamento intencional de conteúdos lecionados por um docente podem configurar situações passíveis de serem classificadas como fraude. No entanto, dada a ambiguidade dos seus motivos e o valor moral discutível dos seus significados, optou-se por delimitar a fraude nos termos propostos.

No caso deste livro, aborda-se a fraude académica cometida pelos alunos, entendida como qualquer transgressão moral praticável por um aluno no contexto das suas relações académicas e das suas responsabilidades perante professores, colegas e a instituição que o acolbe.

Com base neste enquadramento conceptual, propõe-se uma tipologia da fraude académica cometida por alunos que distingue quatro categorias de transgressão:

- apropriação de trabalho alheio;

- simulação de trabalho não realizado; 
- facilitação da fraude a terceiros;

- ocultação da fraude (não denúncia).

Estas categorias correspondem a formas diferentes de cometer fraude académica, ou seja, de comprometer a justiça na avaliação de desempenhos, competências e conhecimentos dos alunos. As primeiras três categorias podem ainda ser desdobradas, resultando numa tipologia com sete variantes possíveis, além da ocultação de cada uma delas, tal como apresentada no Quadro 1.

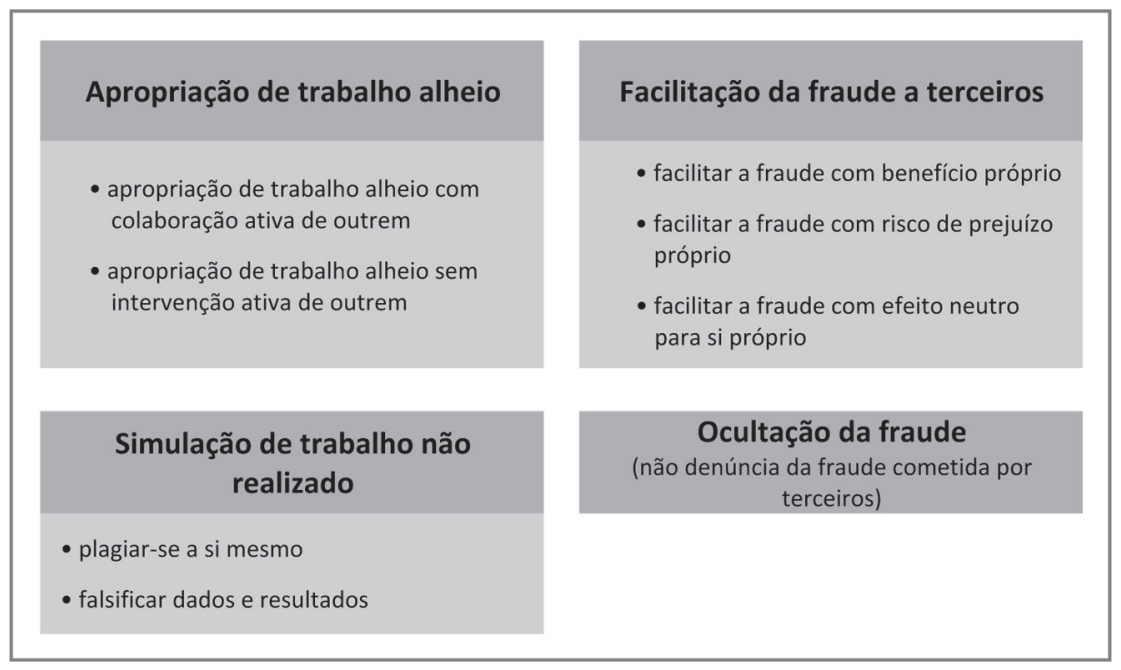

Quadro 1. Tipologia da Fraude Académica cometida por Alunos

Nos termos propostos, a tradicional cópia por um colega ou por apontamentos não autorizados em exame, ou a cópia não creditada de fontes conhecidas e desconhecidas em trabalhos, são práticas que passam a poder ser entendidas num modelo teórico mais vasto de fraude académica. Esta conceção permite analisar e compreender como as diferentes práticas fraudulentas se articulam entre si, qual o seu significado e quais as dinâmicas relacionais subjacentes que as permitem. 
A apropriação diz respeito à apresentação como seu, de trabalho realizado por outrem. A facilitação diz respeito à contribuição intencional para que outro se aproprie de trabalho que não realizou, apresentando-o como seu. A simulação diz respeito à apresentação como verdadeiro ou original, de trabalho que não é. A ocultação diz respeito à não denúncia de fraude que se observa nos outros.

Como ilustração, apresentam-se os seguintes exemplos de práticas e seu respetivo enquadramento no modelo proposto:

\begin{tabular}{|ll|}
\hline Apropriação com colaboração ativa de outrem & comprar um trabalho \\
\hline Apropriação sem colaboração ativa de outrem & $\begin{array}{l}\text { copiar trabalho da Internet } \\
\text { apresentar o mesmo trabalho em diferentes } \\
\text { disciplinas }\end{array}$ \\
\hline Falsificar dados e resultados & inventar dados \\
\hline Facilitar a fraude com benefício próprio & vender trabalho a colega \\
\hline Facilitar a fraude com risco de prejuizo próprio & deixar copiar em exame \\
\hline Facilitar a fraude com efeito neutro para si próprio & $\begin{array}{l}\text { permitir que colega assine trabalho no qual } \\
\text { não colaborou }\end{array}$ \\
\hline
\end{tabular}

Estas práticas são apenas exemplos concretos de como cada tipo de fraude se pode manifestar no comportamento dos alunos. A simplificação da sua descrição pode, em certos casos, suscitar alguma ambiguidade, embora o sentido fundamental do que pretendem ilustrar se mantenha evidente. Esta tipologia é uma proposta teórica que visa criar um quadro coerente e abrangente que facilite a análise do comportamento ético dos alunos e, em particular, das práticas consideradas fraudulentas em contexto académico, no âmbito dos seus compromissos explícitos e implícitos com colegas, docentes e instituições de ensino. 


\section{A P I T U L O I I}

\section{A FRAUDE ACADÉmICA}

\section{COMETIDA PORALUNOS EM PORTUGAL}

\subsection{O estudo dos alunos em Portugal}

\subsubsection{Objetivos do estudo}

O perfil ético revelado por um aluno ao longo do seu percurso académico pode ser um indicador importante das suas predisposições psicológicas e morais em contexto de trabalho e das relações sociais pós-universitárias. Para a generalidade dos alunos, a frequência do ensino superior corresponde a um período das suas vidas fundamental na consolidação de um sistema de valores alinhados com as expectativas sociais e profissionais. Por isso, o estudo da ética dos alunos do ensino superior é essencial para compreender e antecipar o seu comportamento futuro, quer em termos profissionais, quer em termos pessoais.

O objetivo principal deste estudo é analisar a atitude dos alunos do $1 .^{\circ}$ ciclo do ensino superior em Portugal perante a fraude académica cometida por alunos. Em concreto, pretende-se conhecer qual a sua perceção sobre a frequência das práticas fraudulentas entre colegas, qual a gravidade que atribuem aos diferentes tipos de transgressão e quais os fatores que, na sua opinião, os motivam ou poderão inibir. Trata-se, portanto, de um estudo sobre as perceções e opiniões dos alunos acerca da fraude académica. 
Propõe-se assim contribuir para conhecer o perfil moral do aluno do ensino superior em Portugal, em termos agregados e também desagregados por área científica, através da forma como ele se posiciona perante a fraude académica. Eis as sete perguntas principais às quais se pretende responder neste estudo:

1. Qual a perceção dos alunos do ensino superior sobre a frequência das práticas de fraude académica?

2. Quais as práticas de fraude académica que os alunos consideram mais graves e menos graves?

3. Qual a tipologia de fraude académica subjacente aos diferentes níveis de gravidade atribuída pelos alunos?

4. Qual o grau de predisposição dos alunos para cometerem fraude académica?

5. Qual o grau de predisposição dos alunos para denunciarem a fraude académica?

6. Quais os motivos principais para cometer fraude académica?

7. Quais os principais fatores que poderão inibir a prática de fraude académica?

\subsubsection{Seleção da amostra de alunos}

Tendo como universo de estudo a totalidade dos alunos que frequentam o $1 .^{\circ}$ ciclo e programas similares no ensino superior em Portugal, a amostra foi definida a partir dos dados sobre os alunos inscritos no ensino superior em Portugal no ano letivo 2009/2010, obtidos a partir da informação disponibilizada pelo GPEARI (Gabinete de Estratégia, Planeamento, Avaliação e Relações Internacionais) do Ministério da Ciência, Tecnologia e Ensino Superior ${ }^{2}$. Com base nesta

\footnotetext{
2 http://www.gpeari.mctes.pt/ (consultado em 18/03/2011)
} 
informação foram adotados os seguintes critérios sequenciais para selecionar a amostra de alunos a inquirir em Portugal:

i) Foram considerados quatro subsistemas de ensino superior $^{3}$ : Ensino Superior Público Universitário (UPU); Ensino Superior Privado Universitário (UPR) ${ }^{4}$; Ensino Superior Público Politécnico (PPU); Ensino Superior Privado Politécnico (PPR).

ii) Foram considerados apenas cursos classificados como "Bacharelato em Ensino + Licenciatura em Ensino", "Bacharelato + Licenciatura", "Licenciatura", Licenciatura - $1^{\circ}$ ciclo" e "Mestrado Integrado".

iii) Foi excluída a Universidade Aberta devido à particularidade do seu método de ensino à distância, o qual distorce a representatividade dos alunos inscritos nas restantes instituições com métodos de ensino presencial.

iv) Em cada um dos quatro subsistemas de ensino superior, os cursos foram agrupados por Áreas de Educação e Formação (AEF), tal como definidas na Classificação Nacional das Áreas de Educação e Formação (CNAEF)' .

v) Em cada um dos quatro subsistemas de ensino superior, foram incluídas na amostra as AEF que representassem $80 \%$ da totalidade de alunos inscritos, selecionados por ordem decrescente da sua representatividade dentro do respetivo subsistema de ensino.

3 Devido à especificidade dos seus conteúdos e à baixa representatividade na totalidade dos alunos no ensino superior em Portugal, foram excluídos da análise os subsistemas Ensino Superior Público Militar e Policial Universitário e Ensino Superior Público Militar e Policial Politécnico.

${ }^{4}$ Inclui ensino superior concordatário (Universidade Católica Portuguesa).

5 Portaria n. ${ }^{\circ}$ 256/2005, de 16 de Março (Diário da República - I Série-B, $n{ }^{\circ}{ }^{53)}$ 
vi) Foi calculada a representatividade de cada uma das AEF selecionadas (nos quatro subsistemas) na totalidade do universo considerado de alunos do ensino superior.

vi) Identificou-se a AEF com menor representatividade 6 e considerou-se que essa percentagem corresponderia a 30 questionários (este limite mínimo de alunos a questionar por AEF corresponde ao número mínimo de observações habitualmente considerado necessário para uma análise estatística multivariada significativa).

viii) Foi calculado o número de questionários a aplicar em cada AEF incluída na amostra a partir da proporção identificada anteriormente $(0,278 \%$ equivale a 30 questionários) e considerando a representatividade de cada uma no ensino superior.

ix) Para selecionar os cursos - e definir o respetivo número de questionários a aplicar em cada um - em cada AEF, foram adotados os seguintes critérios, respeitando o equilíbrio entre os princípios de eficiência na recolha de dados e de uma dispersão regional mínima aceitável:

. número máximo de cursos por AEF: 5

. número mínimo de questionários por curso: 20

. a distribuição do número de questionários por curso foi efetuada de acordo com a proporção que cada um dos 5 cursos representa no seu conjunto (sempre que esse número era inferior a 20, diminuía-se o número de cursos até atingir esse mínimo, retendo apenas os cursos necessários até alcançar esse limite e recalculando a proporcionalidade)

${ }^{6}$ AEF 214 no PPR: Design (639 alunos, representando 0,278\% do total de alunos do ensino superior) 
Este método permitiu definir uma amostra de 11.638 alunos, de 252 cursos de 127 instituições de ensino superior (incluindo Escolas, Faculdades e Departamentos), correspondente a 3,78\% do total de alunos inscritos no ensino superior em Portugal (excluindo os subsistemas Militar e Policial Universitário e Politécnico). A Tabela 1 apresenta a representação de cada um dos subsistemas de ensino na amostra total.

\begin{tabular}{|l|c|c|c|}
\hline $\begin{array}{l}\text { Subsistema de Ensino } \\
\text { Superior }\end{array}$ & $\begin{array}{c}\text { N. }{ }^{\circ} \text { de alunos a } \\
\text { inquirir }\end{array}$ & $\begin{array}{c}\text { Representação na } \\
\text { totalidade de alunos } \\
\text { no ensino superior }\end{array}$ & $\begin{array}{c}\text { Representação na } \\
\text { totalidade de alunos } \\
\text { da amostra }\end{array}$ \\
\hline $\begin{array}{l}\text { Ensino Superior Público } \\
\text { Universitário (UPU) }\end{array}$ & 4900 & $1,59 \%$ & $42,10 \%$ \\
\hline $\begin{array}{l}\text { Ensino Superior Privado } \\
\text { Universitário (UPR) }\end{array}$ & 1996 & $0,65 \%$ & $17,15 \%$ \\
\hline $\begin{array}{l}\text { Ensino Superior Público } \\
\text { Politécnico (PPU) }\end{array}$ & 3757 & $1,22 \%$ & $32,29 \%$ \\
\hline $\begin{array}{l}\text { Ensino Superior Privado } \\
\text { Politécnico (PPR) }\end{array}$ & 985 & $0,32 \%$ & $8,46 \%$ \\
\hline
\end{tabular}

Tabela 1. Amostra inicial de alunos do ensino superior português a inquirir

\subsubsection{O método de recolha de dados}

Para concretizar os objetivos deste estudo, optou-se por recolher respostas dos alunos por questionário, em papel, aplicado presencialmente em sala de aula, com breve explicação prévia dos seus objetivos. Esta opção metodológica visou maximizar a taxa e a qualidade das respostas, já que os questionários foram aplicados em sala de aula, com a presença física de um colaborador ou docente envolvido no estudo, disponível para esclarecer qualquer dúvida. Os questionários foram recolhidos imediatamente após o seu preenchi-

7 Esta representatividade coincide com a proporção de cada um dos quatro subsistemas de ensino na totalidade de alunos inscritos no ensino superior (em $1 .^{\circ}$ ciclo ou programas similares). 
mento pelos alunos. Todas as instituições de ensino superior incluídas na amostra selecionada foram contactadas a fim de autorizarem e facilitarem o acesso a docentes que aceitassem que a aplicação de questionários fosse realizada numa das suas aulas.

Foi ainda pedido aos alunos que indicassem no questionário um contacto, caso aceitassem participar num painel de alunos a ser inquirido dois anos mais tarde sobre o mesmo tema, com um questionário idêntico, no âmbito deste estudo. A criação deste painel visava analisar a evolução do pensamento dos alunos ao longo do seu percurso académico.

O questionário utilizado foi integralmente construído pela equipa de investigação, tratando-se de uma proposta original em face dos instrumentos disponíveis na literatura científica para recolha de dados relativos à fraude académica. Esta opção foi motivada pelo facto de se propor neste estudo uma nova tipologia de fraude académica, a qual obriga à construção de um questionário adaptado a esse modelo teórico de entendimento da fraude. Por outro lado, os objetivos ambiciosos do estudo obrigaram igualmente à formulação de questões raramente incluídas neste tipo de pesquisas, tais como, por exemplo, o questionamento sobre quais os motivos e quais os inibidores da fraude.

A elaboração e validação do questionário passou, essencialmente, pelas seguintes etapas sequenciais:

1) Construção: a primeira versão do questionário foi elaborada com base em sugestões extraídas da literatura relevante ${ }^{8}$, com base na experiência dos autores e nos contributos de alunos e docentes em debates abertos promovidos pelos autores sobre o tema.

8 Nomeadamente as propostas de Morris e Kilian (2006), com adaptações inspiradas pelos trabalhos de McCabe (1999), de Rennie e Rudland (2003) e também pelas pesquisas de Teixeira e Rocha (2010). 
2) Pré-teste 1: a primeira versão do questionário foi testada através de um estudo realizado na Faculdade de Economia da Universidade de Coimbra em 2008 com 452 alunos das quatro licenciaturas (Economia, Gestão, Sociologia e Relações Internacionais), tendo os resultados preliminares sido apresentados e discutidos em congresso científico internacional, após o qual foi necessário rever e aperfeiçoar alguns aspetos do seu conteúdo.

3) Pré-teste 2: a versão revista do questionário foi testada através de um estudo realizado na Universidade de Coimbra em 2011 com 450 estudantes de 8 licenciaturas de $1^{\circ}$ ciclo, a fim de obter uma versão final adequada aos objetivos do estudo, teoricamente robusta e estruturalmente válida.

Após o $2 .^{\circ}$ pré-teste, foram efetuadas as últimas correções ao texto de algumas perguntas e o questionário foi considerado pronto para ser aplicado no estudo de campo, o qual decorreu durante o ano letivo 2011/2012.

\subsubsection{O Questionário}

O questionário utilizado para recolha de dados, designado "Inquérito aos alunos sobre a ética das práticas académicas no ensino superior", continha apenas questões de resposta quantitativa ou de escolha múltipla e era constituído por 3 partes, com a seguinte estrutura 9 :

- PARTE I: continha 19 questões e destinava-se genericamente a recolher dados demográficos do aluno, exceto a questão

9 O ANEXO 1 "Questionário aos Alunos" apresenta o questionário completo, tal como foi aplicado neste estudo. 
I.18 (na qual se pretendia saber se o aluno sabia e conhecia o regulamento disciplinar da sua instituição) e a questão I.19 (na qual se pretendia conhecer qual a perceção geral do aluno em relação à frequência da prática de fraude entre os alunos do seu curso).

- PARTE II: apresentava 9 cenários (oito situações e uma delas desdobrada em duas), envolvendo personagens fictícias em práticas de possível fraude académica, sendo solicitada a opinião do aluno sobre a gravidade de cada prática, sobre se faria o mesmo naquela situação e sobre se a denunciaria caso tivesse conhecimento dela.

- PARTE III: continha 4 questões de escolha múltipla para avaliar a opinião do aluno sobre a aceitabilidade da fraude académica, a frequência de algumas práticas, os fatores que a motivam e os fatores que a poderão inibir.

Ao utilizar cenários projetivos para avaliar a atitude dos alunos perante a fraude pretendeu-se minimizar o efeito da resposta socialmente desejável, já que era solicitada a opinião sobre a gravidade das práticas fraudulentas cometidas por uma personagem fictícia. Além disso, ao questionar o aluno se ele, naquela situação, faria o mesmo, evita-se igualmente perguntar-lhe diretamente se ele pratica ou não fraude académica, o que facilita uma resposta mais verdadeira. Desta forma, a PARTE II do questionário não se destina a conhecer quais as práticas reais de cada aluno, mas qual a sua opinião sobre a gravidade da fraude e qual a sua predisposição para cometê-la ou para denunciá-la. Os nove cenários contemplavam 7 práticas de apropriação, 4 práticas de facilitação, 2 práticas de simulação e 9 práticas de ocultação, tal como descritas no Quadro 2. 


\begin{tabular}{|c|c|c|}
\hline \multicolumn{2}{|c|}{ Tipos de Fraude } & Práticas de Fraude \\
\hline \multirow[t]{2}{*}{ APROPRIAR } & $\begin{array}{l}\text { Apropriar com colaboração } \\
\text { ativa de outrem }\end{array}$ & $\begin{array}{l}\text { Copiar em exame } \\
\text { Comprar trabalho } \\
\text { Assinar trabalho sem ser autor } \\
\text { Copiar trabalho de colega com a sua autorização } \\
\text { Apresentar trabalho realizado por um familiar }\end{array}$ \\
\hline & $\begin{array}{l}\text { Apropriar sem colaboração } \\
\text { ativa de outrem }\end{array}$ & $\begin{array}{l}\text { Copiar por cábulas em exame } \\
\text { Copiar da Internet }\end{array}$ \\
\hline \multirow{2}{*}{ SIMULAR } & Auto-plágio & $\begin{array}{l}\text { Apresentar o mesmo trabalho em diferentes } \\
\text { disciplinas }\end{array}$ \\
\hline & Falsificar dados e resultados & Inventar dados \\
\hline \multirow{3}{*}{ FACILITAR } & $\begin{array}{c}\text { Facilitar a fraude com benefício } \\
\text { próprio }\end{array}$ & Vender trabalho a colega \\
\hline & $\begin{array}{l}\text { Facilitar a fraude com risco de } \\
\text { prejuizo próprio }\end{array}$ & Deixar copiar em exame \\
\hline & $\begin{array}{l}\text { Facilitar a fraude com efeito } \\
\text { neutro para si próprio }\end{array}$ & $\begin{array}{l}\text { Permitir que colega assine trabalho no qual não } \\
\text { colaborou } \\
\text { Emprestar trabalho para ser copiado }\end{array}$ \\
\hline
\end{tabular}

Quadro 2. Práticas de Fraude Académica analisadas

Na PARTE III foi incluída uma primeira pergunta para avaliar qual a opinião do aluno sobre a aceitabilidade da fraude académica em geral, procurando distinguir aqueles que a consideram aceitável desde que não prejudique ninguém diretamente, daqueles que a consideram inaceitável em qualquer circunstância. Ao não apresentar cenários ou práticas, esta questão permite entender qual a atitude mais geral de cada aluno perante a fraude, distinguindo uma visão mais utilitarista, legitimadora da fraude, de uma abordagem mais deontológica, intransigente com a transgressão. A criação destes dois subgrupos de alunos permite, entre outras análises, avaliar como se diferenciam as suas opiniões sobre os motivos da fraude e, principalmente, sobre os fatores que a poderão inibir. 


\subsubsection{Descrição da amostra final}

Os questionários anónimos foram aplicados presencialmente, recolhidos e posteriormente validados, tendo sido eliminados todos aqueles que se apresentassem muito incompletos ou significativamente rasurados. Após esta validação, a amostra final fixou-se em 7.292 questionários, o que corresponde a $62,7 \%$ da amostra inicialmente definida. Em termos de representação do universo do ensino superior em Portugal, o Ensino Superior Público Politécnico é o mais representado na amostra final (83,3\%) e o Ensino Superior Privado Universitário o menos representado $(27,1 \%)$, tal como pode ser observado na Tabela 2 .

\begin{tabular}{|lccc|}
\hline \multicolumn{1}{|c}{$\begin{array}{c}\text { Subsistema de Ensino } \\
\text { Superior }\end{array}$} & $\begin{array}{c}\text { N.o de alunos a } \\
\text { inquirir }\end{array}$ & $\begin{array}{c}\text { N.o de respostas } \\
\text { validadas }\end{array}$ & $\begin{array}{c}\text { Taxa de resposta } \\
\text { obtida }\end{array}$ \\
\hline $\begin{array}{l}\text { Ensino Superior Público } \\
\text { Universitário (UPU) }\end{array}$ & 4.900 & 2939 & $60 \%$ \\
\hline $\begin{array}{l}\text { Ensino Superior Privado } \\
\text { Universitário (UPR) }\end{array}$ & 1.996 & 542 & $27,1 \%$ \\
\hline $\begin{array}{l}\text { Ensino Superior Público } \\
\text { Politécnico (PPU) }\end{array}$ & 3.757 & 3130 & $83,3 \%$ \\
\hline $\begin{array}{l}\text { Ensino Superior Privado } \\
\text { Politécnico (PPR) }\end{array}$ & 985 & 681 & $69,1 \%$ \\
\hline \multicolumn{1}{|c|}{ TOTAL } & $\mathbf{1 1 . 6 3 8}$ & $\mathbf{7 . 2 9 2}$ & $\mathbf{6 2 , 7 \%}$ \\
\hline
\end{tabular}

Tabela 2. Amostra final de alunos do ensino superior português inquiridos

A amostra final inclui apenas alunos de nacionalidade portuguesa que estão, pelo menos, no $2 .^{\circ}$ ano de inscrição no ensino superior em Portugal (foram excluídos os alunos que, embora portugueses, estivessem a estudar em Portugal ao abrigo de um programa de mobilidade). Estas restrições visaram minimizar o efeito da cultura na variação dos resultados, assim como assegurar que os alunos 
inquiridos teriam já sido sujeitos a, pelo menos, duas épocas de avaliação no ensino superior.

Esta amostra final inclui, portanto, 7.292 alunos de 182 cursos de 101 instituições de ensino superior portuguesas ${ }^{10}$. Posteriormente à recolha de dados, os cursos foram livremente agrupados por afinidade temática, gerando oito áreas científicas que reúnem 5.751 alunos (78,9\% da amostra final), o que permitiu que, além da análise da amostra total, fosse também realizada uma análise comparativa entre alunos por área científica. No Quadro 3 são apresentadas as 51 designações de curso agrupadas em cada área científica e o respetivo número de alunos questionado em cada uma.

10 O ANEXO 3 apresenta uma tabela com os cursos que foram estudados e a respetiva distribuição da amostra final por curso. 


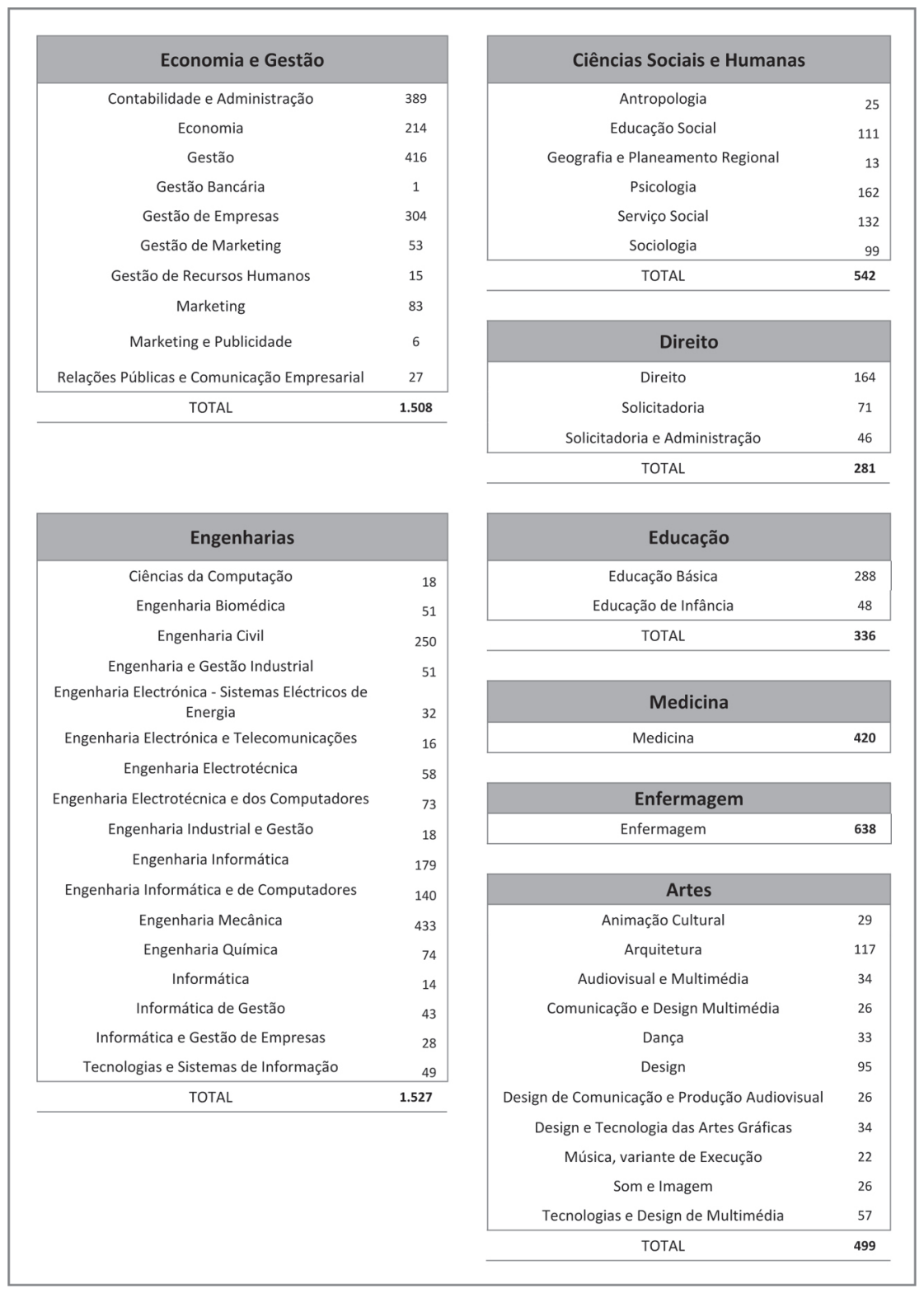

Quadro 3. Áreas Científicas, Cursos e número de Alunos 
Do ponto de vista das características demográficas dos alunos inquiridos, a amostra total é constituída por $60,1 \%$ de mulheres e $39,9 \%$ de homens, provenientes de todas as grandes regiões do país. Outros dados revelam que $88,9 \%$ dos alunos inquiridos fizeram o percurso académico pré-universitário em escolas públicas, estando $77,7 \%$ a frequentar o curso da sua primeira opção na candidatura ao ensino superior. Também 81,9\% são alunos regulares sem cargos dirigentes ou estatutos especiais, enquanto $15,5 \%$ da amostra são trabalhadores-estudantes. A Tabela 3 apresenta uma síntese dos dados demográficos mais relevantes da amostra total e das subamostras de cada uma das oito áreas científicas consideradas.

\begin{tabular}{|c|c|c|c|c|c|c|}
\hline & & Mulheres & $\begin{array}{l}\text { Percurso Pré- } \\
\text { universitário em } \\
\text { Escola Pública }\end{array}$ & $\begin{array}{c}\text { Curso que } \\
\text { frequenta foi } \\
\text { primeira escolha }\end{array}$ & $\begin{array}{l}\text { Aluno regular } \\
\text { sem estatutos } \\
\text { especiais }\end{array}$ & $\begin{array}{c}\text { Média atual } \\
\text { de curso }\end{array}$ \\
\hline Amostra Total & 7.292 & $60,1 \%$ & $88,9 \%$ & $77,7 \%$ & $81,9 \%$ & 13,2 \\
\hline Economia e Gestão & 1.508 & $59,9 \%$ & $87,3 \%$ & $77,3 \%$ & $69,2 \%$ & 12,7 \\
\hline Engenharias & 1.527 & $22,7 \%$ & $89,1 \%$ & $79,1 \%$ & $84,4 \%$ & 12,6 \\
\hline Medicina & 420 & $69,5 \%$ & $79,0 \%$ & $97,6 \%$ & $93,3 \%$ & 14,2 \\
\hline Enfermagem & 638 & $87,3 \%$ & $91,1 \%$ & $78,3 \%$ & $87,6 \%$ & 14,1 \\
\hline Educação & 336 & $95,8 \%$ & $91,7 \%$ & $83,6 \%$ & $81,4 \%$ & 14,0 \\
\hline Direito & 281 & $77,6 \%$ & $88,3 \%$ & $81,4 \%$ & $72,9 \%$ & 12,2 \\
\hline $\begin{array}{c}\text { Ciências Sociais e } \\
\text { Humanas }\end{array}$ & 542 & $87,8 \%$ & $93,5 \%$ & $68,5 \%$ & $80,3 \%$ & 13,5 \\
\hline Artes & 499 & $53,4 \%$ & $88,7 \%$ & $75,7 \%$ & $88,0 \%$ & 13,6 \\
\hline
\end{tabular}

Tabela 3. Dados demográficos da amostra final

\subsection{A frequência da fraude}

A perceção individual sobre a frequência com que ocorre fraude académica é naturalmente influenciada pelas circunstâncias particulares de quem a observa ou intui. Essa perceção poderá porventura até depender da frequência com que cada aluno que respondeu ao questionário também a pratica. Em todo o caso, em termos agregados, trata-se de um indicador importante para conhecer a forma 
como os alunos percebem o seu contexto académico e a cultura mais transgressiva ou mais cumpridora que o caracteriza.

A pergunta que visava saber qual a perceção geral dos alunos sobre a frequência de práticas fraudulentas no seu contexto académico, com a respetiva resposta agregada, é a seguinte:

Na sua opinião, com que frequência os alunos, no seu curso, cometem algum tipo de fraude académica (por exemplo, copiar numa prova escrita)?
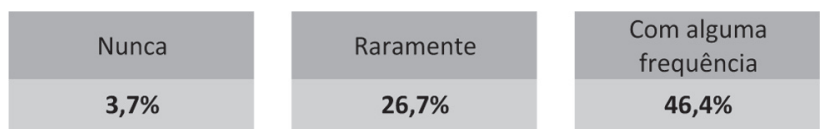

Regularmente

$23,2 \%$

É significativo observar que $69,6 \%$ dos alunos reconhecem uma ocorrência frequente ou regular de fraude académica no seu contexto. Esta perceção varia, no entanto, consoante algumas características específicas dos alunos. A perceção sobre a frequência de práticas fraudulentas é maior em alunos:

. mulheres

. cujo percurso pré-universitário foi feito maioritariamente em escolas privadas

. que ainda não reprovaram

. com mais inscrições no ensino superior

. com média mais alta

. que dizem não existir regulamento disciplinar na sua instituição

. cujas mães têm escolaridade superior

. dirigentes associativos 
Este resultado revela um perfil-tipo de aluno mais sensível ao reconhecimento de práticas fraudulentas no ambiente escolar que o rodeia, embora não necessariamente porque as condene ou pratique. Do ponto de vista dos indicadores mais relevantes, trata-se portanto de uma aluna mulher, com bom desempenho académico e com mais tempo de frequência no ensino superior.

Quando comparadas as oito áreas científicas, as perceções sobre a frequência de fraude não variam muito, tal como pode ser observado na Tabela 4. Comparativamente, destacam-se as Engenharias e o Direito como áreas onde a ocorrência de fraude é percecionada como mais baixa (maior percentagem de respostas "Nunca" ou "Raramente"), ao contrário das áreas de Enfermagem e Educação onde a perceção dos alunos sugere uma frequência mais alta de práticas fraudulentas (maior percentagem de respostas "Com alguma frequência" ou "Regularmente").

\begin{tabular}{|c|c|c|c|c|}
\hline & Nunca & Raramente & $\begin{array}{l}\text { Com alguma } \\
\text { frequência }\end{array}$ & Regularmente \\
\hline Economia e Gestão & $4,5 \%$ & $26,5 \%$ & $47,2 \%$ & $21,7 \%$ \\
\hline Engenharias & $5,4 \%$ & $32,0 \%$ & $41,0 \%$ & $21,0 \%$ \\
\hline Medicina & $1,2 \%$ & $31,0 \%$ & $43,2 \%$ & $24,6 \%$ \\
\hline Enfermagem & $3,0 \%$ & $17,6 \%$ & $51,7 \%$ & $27,7 \%$ \\
\hline Educação & $1,2 \%$ & $22,0 \%$ & $56,3 \%$ & $20,5 \%$ \\
\hline Direito & $7,6 \%$ & $27,8 \%$ & $44,0 \%$ & $20,6 \%$ \\
\hline Ciências Sociais e Humanas & $3,5 \%$ & $25,5 \%$ & $48,0 \%$ & $22,9 \%$ \\
\hline Artes & $3,2 \%$ & $29,9 \%$ & $45,2 \%$ & $21,7 \%$ \\
\hline
\end{tabular}

Tabela 4. Frequência de Fraude Académica por área científica

Além da perceção sobre a frequência geral de fraude, foi também perguntado aos alunos qual a sua opinião sobre a frequência com que ocorrem 11 práticas específicas de fraude e a frequência com que ela é denunciada. A Tabela 5 apresenta essas práticas ordenadas da mais frequente à menos frequente. Entre elas, destacam-se como práticas mais frequentes Utilizar materiais não autorizados 
na realização de provas escritas e Copiar numa prova escrita pelas respostas de um colega. As práticas menos frequentes referem-se a Comprar trabalhos académicos fora da escola e Comprar trabalhos a outros colegas. Quando questionados sobre a prática de Denunciar fraudes académicas cometidas por colegas, uma ampla maioria dos alunos reconhece que ela nunca ocorre ou que ocorre raramente.

\section{Perceção sobre Frequência das Práticas de Fraude}

(por ordem decrescente de ocorrência)

\begin{tabular}{|c|c|}
\hline 1 & Utilizar materiais não autorizados na realização de provas escritas \\
\hline 2 & Copiar numa prova escrita pelas respostas de um colega \\
\hline 3 & Deixar copiar respostas num exame \\
\hline 4 & Assinar um trabalho de grupo sem ter colaborado na realização do mesmo \\
\hline 5 & Copiar partes de trabalhos de outros autores sem os citar \\
\hline 6 & Copiar trabalhos de outros colegas \\
\hline 7 & Copiar trabalhos da Internet \\
\hline 8 & Apresentar trabalhos práticos com dados inventados \\
\hline 9 & Apresentar o mesmo trabalho em várias disciplinas \\
\hline 10 & Comprar trabalhos académicos fora da escola \\
\hline 11 & Comprar trabalhos a outros colegas \\
\hline
\end{tabular}

Tabela 5. Frequência das Práticas de Fraude Académica

Eis a síntese dos principais resultados sobre a frequência das práticas de fraude académica, segundo a perceção dos alunos:

\section{COPIAR EM EXAME}

$\mathbf{7 1 , 1} \%$ dos alunos portugueses consideram que se copia por materiais não autorizados em exame escrito com alguma fre- 
quência $(40,9 \%)$ ou regularmente $(30,2 \%)$. $\mathbf{7 2 , 7 \%}$ dos alunos portugueses consideram que se copia pelas respostas de um colega em exame escrito com alguma frequência $(48,1 \%)$ ou regularmente $(24,6 \%)$.

\section{COPIAR EM TRABALHO}

$\mathbf{5 4 , 2} \%$ dos alunos portugueses consideram que se copia trabalhos da Internet com alguma frequência (39,3\%) ou regularmente $(14,9 \%)$.

$\mathbf{8 8 , 8} \%$ dos alunos portugueses consideram que nunca $(28,8 \%)$ ou raramente $(50 \%)$ se apresenta o mesmo trabalho em várias disciplinas.

\section{COMPRAR TRABALHO}

$\mathbf{9 1 , 4 \% ~ d o s ~ a l u n o s ~ p o r t u g u e s e s ~ c o n s i d e r a m ~ q u e ~ n u n c a ~}(50,4 \%)$ ou raramente (41\%) se compram trabalhos a outros colegas. $\mathbf{9 0 , 1} \%$ dos alunos portugueses consideram que nunca (46,3\%) ou raramente $(43,8 \%)$ se compram trabalhos fora da escola.

\section{NÃO DENUNCIAR}

$\mathbf{9 8 , 2} \%$ dos alunos portugueses consideram que nunca $(65,4 \%)$ ou raramente $(32,8 \%)$ se denunciam fraudes académicas cometidas por colegas.

Os resultados sugerem que as fraudes mais frequentes ocorrem na realização de provas escritas. A tendência atual para a substituição total ou parcial destas provas pela realização de trabalhos individuais ou em grupo parece também ser, além das justificações metodológicas de ensino e aprendizagem que a incentivam, uma resposta a esta perceção de incidência acentuada de fraude cometida durante os exames. Contudo, para contextualizar devidamente esta perceção, convém não esquecer que os alunos foram inquiridos 
numa fase da sua trajetória académica em que tendem a predominar as avaliações por provas escritas e que os trabalhos individuais são mais frequentes num período mais avançado da formação académica. Copiar trabalhos de colegas ou assinar autoria de trabalhos sem ter colaborado na sua realização também parece ser uma prática frequente, enquanto a compra de trabalhos quase não ocorre, quer na amostra total, quer em qualquer uma das subamostras por área científica. O sistema de colaboração entre colegas na prática de fraude, no $1 .^{\circ}$ ciclo do ensino superior, parece prevalecer sobre um eventual mercado de transação económica para compra e venda de trabalhos académicos. A denúncia de fraude pelos alunos é quase inexistente, o que reforça esta interpretação de que existe uma cultura de tolerância e de encobrimento da fraude entre os alunos, porventura baseada num sistema de cumplicidades e de reciprocidades que a legitima e alimenta.

\subsection{A gravidade da fraude}

Para avaliar a opinião dos alunos sobre as práticas de fraude académica, foi-lhes solicitado que se pronunciassem sobre 13 práticas (7 de apropriação, 4 de facilitação e 2 de simulação) apresentadas em nove cenários simulados com personagens fictícias. Para cada prática era perguntado ao aluno se a considerava fraude e qual a gravidade que lhe atribuía, numa escala de 1 a 10 .

As práticas consideradas mais graves estão relacionadas com a compra e venda de trabalhos (médias de gravidade de 8,43 e 7,36, respetivamente), enquanto a menos grave é a apresentação do mesmo trabalho em diferentes disciplinas (média de 4,18), sendo que $33,7 \%$ dos alunos nem a reconhece como uma prática fraudulenta. Curiosamente, $89,1 \%$ dos alunos considera que é fraude fornecer respostas a um colega num exame, mas apenas $63,9 \%$ considera ser 
fraude permitir que um colega partilhe a autoria formal de um trabalho no qual não participou. A Tabela 6 apresenta as percentagens das respostas obtidas, assim como a média de gravidade atribuída a cada prática.

\begin{tabular}{|c|c|c|c|c|c|}
\hline & & \multirow{2}{*}{$\begin{array}{c}\text { Gravidade da prática } \\
\text { (1-10) }\end{array}$} & \multicolumn{3}{|c|}{ Esta prática é fraude académica? } \\
\hline & & & "Sim" & "Não" & "Não sei" \\
\hline 1 & Comprar trabalho a colega & 8,43 & $95,4 \%$ & $2,1 \%$ & $2,6 \%$ \\
\hline 2 & $\begin{array}{l}\text { Vender aos colegas trabalhos realizados por si } \\
\text { próprio }\end{array}$ & 7,36 & $88,4 \%$ & $7,7 \%$ & $3,9 \%$ \\
\hline 3 & Obter a colaboração de familiar & 6,87 & $86,9 \%$ & $10,1 \%$ & $3,0 \%$ \\
\hline 4 & Plágio autorizado do trabalho de um colega & 6,72 & $90,0 \%$ & $7,2 \%$ & $2,8 \%$ \\
\hline 5 & $\begin{array}{l}\text { Consultar materiais não autorizados numa prova } \\
\text { escrita }\end{array}$ & 6,67 & $94,3 \%$ & $3,7 \%$ & $2,0 \%$ \\
\hline 6 & Inventar dados num trabalho escrito & 6,58 & $90,2 \%$ & $5,8 \%$ & $4,0 \%$ \\
\hline 7 & Copiar trabalho da Internet & 6,29 & $84,4 \%$ & $12,2 \%$ & $3,3 \%$ \\
\hline 8 & $\begin{array}{l}\text { Copiar respostas de um colega numa prova } \\
\text { escrita }\end{array}$ & 6,25 & $93,0 \%$ & $4,7 \%$ & $2,3 \%$ \\
\hline 9 & $\begin{array}{l}\text { Não participar em trabalho de grupo, } \\
\text { beneficiando da nota coletiva }\end{array}$ & 6,11 & $78,3 \%$ & $16,8 \%$ & $4,9 \%$ \\
\hline 10 & Fornecer respostas a um colega num exame & 5,67 & $89,1 \%$ & $8,1 \%$ & $2,9 \%$ \\
\hline 11 & $\begin{array}{l}\text { Emprestar a colegas trabalho realizado por si } \\
\text { próprio para que estes apresentem como seu }\end{array}$ & 5,62 & $75,8 \%$ & $20,3 \%$ & $3,9 \%$ \\
\hline 12 & $\begin{array}{l}\text { Permitir que um colega partilhe a autoria formal } \\
\text { de um trabalho sem ter participado nele }\end{array}$ & 4,42 & $63,9 \%$ & $30,8 \%$ & $5,3 \%$ \\
\hline 13 & $\begin{array}{l}\text { Apresentar o mesmo trabalho em diferentes } \\
\text { disciplinas }\end{array}$ & 4,18 & $62,7 \%$ & $33,7 \%$ & $3,6 \%$ \\
\hline
\end{tabular}

Tabela 6. Gravidade da Fraude Académica

Os resultados sugerem que a maioria significativa dos alunos reconhece todos os cenários como situação de fraude académica. Comprar, obter colaboração ou plagiar trabalho é mais grave do que inventar dados, ou seja, a apropriação do trabalho alheio é mais grave do que a sua verdade substantiva. Por outro lado, outras análises permitem concluir que a gravidade média atribuída ao conjunto de práticas de apropriação $(6,97)$ é significativamente diferente da gravidade média atribuída ao conjunto de práticas de 
facilitação $(5,95)^{11}$ e também significativamente diferente da gravidade média atribuída ao conjunto de práticas de simulação $(5,52)^{12}$. A gravidade média atribuída ao conjunto de práticas de simulação também é significativamente diferente da gravidade média atribuída ao conjunto de práticas de facilitação ${ }^{13}$. Ou seja, aparentemente é mais grave apropriar-se de trabalho alheio do que facilitar a apropriação a outro, e é mais grave facilitar a apropriação do trabalho do que simulá-lo.

Com vista a avaliar como os alunos organizam mentalmente as práticas de fraude de acordo com a sua gravidade, foi realizada uma análise fatorial exploratória dos dados ${ }^{14}$. Esta análise permite avaliar se as práticas podem ser agrupadas em subconjuntos homogéneos que sejam explicados por um mesmo fator. Os resultados sugerem que as práticas de fraude estão relacionadas entre si por um critério que não necessariamente aquele que decorre da tipologia proposta, tendo distinguido três fatores, os quais podem ser interpretados nos seguintes termos:

\section{Fator 1 - Fraude na realização de trabalhos académicos \\ Fator 2 - Fraude em exame escrito \\ Fator 3 - Fraude transacional (baseada em transação econó- mica ou afetiva)}

Os alunos parecem assim distinguir a gravidade da fraude consoante a instância de avaliação em que é praticada: na realização de trabalho ou de exame escrito. É no entanto interessante verificar que os alunos diferenciam a fraude quando está em causa o recurso

\footnotetext{
$11 \mathrm{t}$-Student 49,911 (p-value 0,000)

12 t-Student 49,278 ( $p$-value 0,000)

13 t-Student 9,774 ( $p$-value 0,000)

14 Os resultados da Análise Fatorial Exploratória estão incluídos no ANEXO 4.1.
} 
a uma transação económica ou afetiva (com base em relação familiar). Ou seja, talvez prevaleça entre os alunos uma condenação da fraude cometida com recurso a vantagens sociais e económicas que são diferenciadas na medida em que só estão ao alcance de alguns. Assim, para atribuir gravidade às práticas de fraude, os alunos parecem usar como critério, para além da instância de avaliação, e talvez acima dela, a acessibilidade à oportunidade de cometer fraude - que pode ser facilitada ou dificultada pelas condições económicas ou pelo contexto cultural de cada aluno. Este agrupamento das práticas associadas a transação económica ou afetiva num mesmo subgrupo verificou-se em todas as subamostras de cada área científica, confirmando a robustez desta distinção feita pelos alunos com base na gravidade da fraude.

\subsection{A predisposição para a fraude}

A predisposição dos alunos para cometerem fraude académica foi avaliada projetivamente, questionando-os se, caso estivessem na mesma situação de cada uma das personagens fictícias dos nove cenários, fariam o mesmo. Assim, foi possível avaliar a predisposição dos alunos para cometerem cada uma das 13 práticas de fraude contempladas nos cenários apresentados.

Os resultados revelam situações muito diferenciadas. De forma consistente com o nível baixo de gravidade que lhe atribuíram, 73\% dos alunos admitiram que, no cenário apresentado, Apresentariam o mesmo trabalho em diferentes disciplinas, assim como 65,3\% admitiram que Deixariam copiar em exame. Por outro lado, apenas $12 \%$ admitem que Comprariam o trabalho a um colega e apenas 21,5\% admitem que aceitariam Assinar a autoria de um trabalho de grupo sem ter participado nele. A Tabela 7 apresenta estes resultados para a amostra total de alunos. 


\begin{tabular}{|c|c|c|}
\hline & & $\begin{array}{l}\text { Faria o mesmo? } \\
\text { "Sim" }\end{array}$ \\
\hline 1 & $\begin{array}{l}\text { Apresentar o mesmo trabalho em diferentes } \\
\text { disciplinas }\end{array}$ & $73,0 \%$ \\
\hline 2 & Fornecer respostas a um colega num exame & $65,3 \%$ \\
\hline 3 & $\begin{array}{l}\text { Permitir que um colega partilhe a autoria formal } \\
\text { de um trabalho sem ter participado nele }\end{array}$ & $63,1 \%$ \\
\hline 4 & Copiar respostas de um colega numa prova escrita & $52,2 \%$ \\
\hline 5 & $\begin{array}{l}\text { Emprestar a colegas trabalho realizado por si } \\
\text { próprio para que estes apresentem como seu }\end{array}$ & $50,9 \%$ \\
\hline 6 & $\begin{array}{l}\text { Consultar materiais não autorizados numa prova } \\
\text { escrita }\end{array}$ & $44,0 \%$ \\
\hline 7 & Copiar trabalho da Internet & $38,9 \%$ \\
\hline 8 & Obter a colaboração de familiar & $37,1 \%$ \\
\hline 9 & Inventar dados num trabalho escrito & $34,4 \%$ \\
\hline 10 & Plágio autorizado do trabalho de um colega & $30,6 \%$ \\
\hline 11 & $\begin{array}{l}\text { Vender aos colegas trabalhos realizados por si } \\
\text { próprio }\end{array}$ & $26,0 \%$ \\
\hline 12 & $\begin{array}{l}\text { Não participar em trabalho de grupo, } \\
\text { beneficiando da nota coletiva }\end{array}$ & $21,5 \%$ \\
\hline 13 & Comprar trabalho a colega & $12,0 \%$ \\
\hline
\end{tabular}

Tabela 7. Predisposição para cometer Fraude Académica

Os resultados sugerem que a disponibilidade dos alunos para fornecer respostas a um colega durante um exame escrito (65,3\%) é mais alta do que a sua predisposição para copiar por um colega no exame $(52,2 \%)$. É curioso verificar também que a disponibilidade para permitir que um colega seja coautor de um trabalho no qual não participou $(50,9 \%)$ é significativamente maior do que a predisposição para assumir uma coautoria falsa $(21,5 \%)$. Talvez subjacente a estas diferenças esteja 
uma atitude de natural aversão ao risco, apresentando os alunos níveis de inibição mais elevados perante o risco de serem apanhados a copiar ou de serem confrontados com a ignorância ou a denúncia perante um trabalho cujo conteúdo se desconhece ou não entende. Por outro lado, a relação de poder desigual entre quem facilita a fraude e quem a comete também poderá representar uma posição de vulnerabilidade ou de exposição que os alunos considerem menos aceitável no contexto das dinâmicas próprias das suas relações interpares.

Algumas práticas apresentam níveis diferenciados significativos de predisposição dos alunos consoante a área científica a que pertencem. No caso da fraude admitida por mais alunos - Apresentação do mesmo trabalho em diferentes disciplinas -, os alunos de Medicina e das Engenharias destacam-se com uma predisposição acima da média total, enquanto os alunos de Direito revelam a predisposição mais baixa para cometer este tipo de ação. O Gráfico 1 apresenta os resultados comparativos.

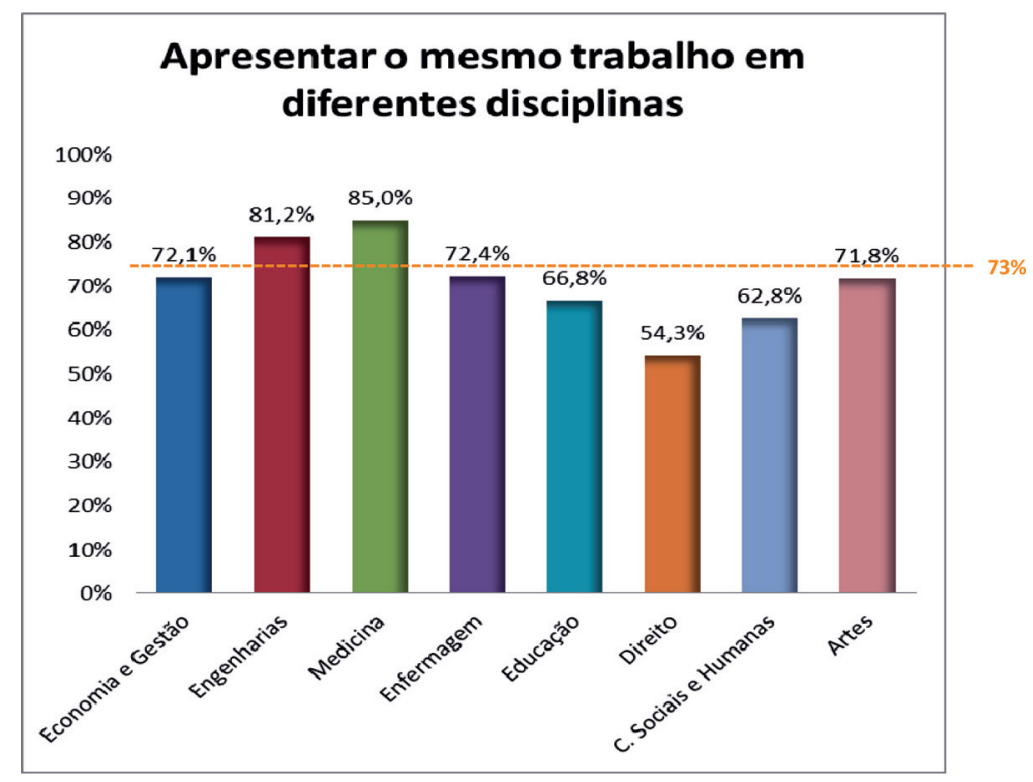

Gráfico 1. Predisposição para Apresentar o mesmo trabalbo em diferentes disciplinas (comparação por área científica) 
Quanto às formas de fraude mais convencionais cometidas durante uma prova escrita, os alunos de Enfermagem apresentam maior predisposição para copiar por um colega e os alunos das Engenharias e das Artes são os mais predispostos a copiar por materiais não autorizados. Em ambos os casos, os alunos de Direito mantêm os níveis mais baixos de predisposição para cometer este tipo de fraudes. Os resultados comparativos para cada uma das práticas podem ser observados com mais detalhes nos Gráficos 2 e 3.

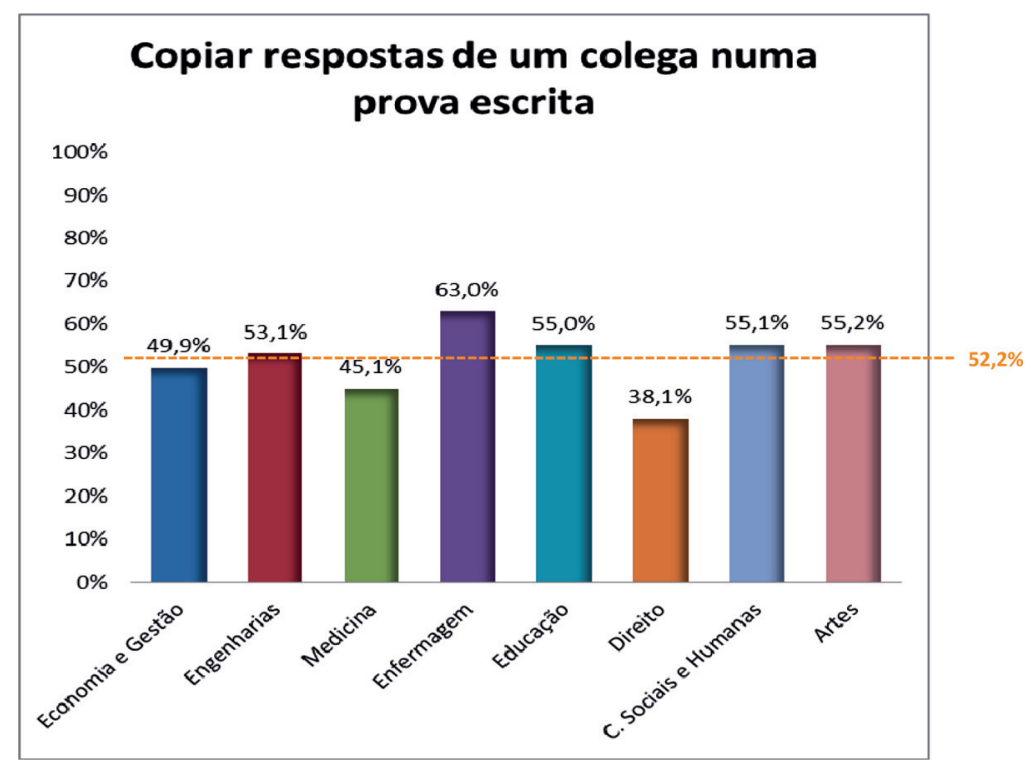

Gráfico 2. Predisposição para Copiar respostas de um colega numa prova escrita (comparação por área científica) 


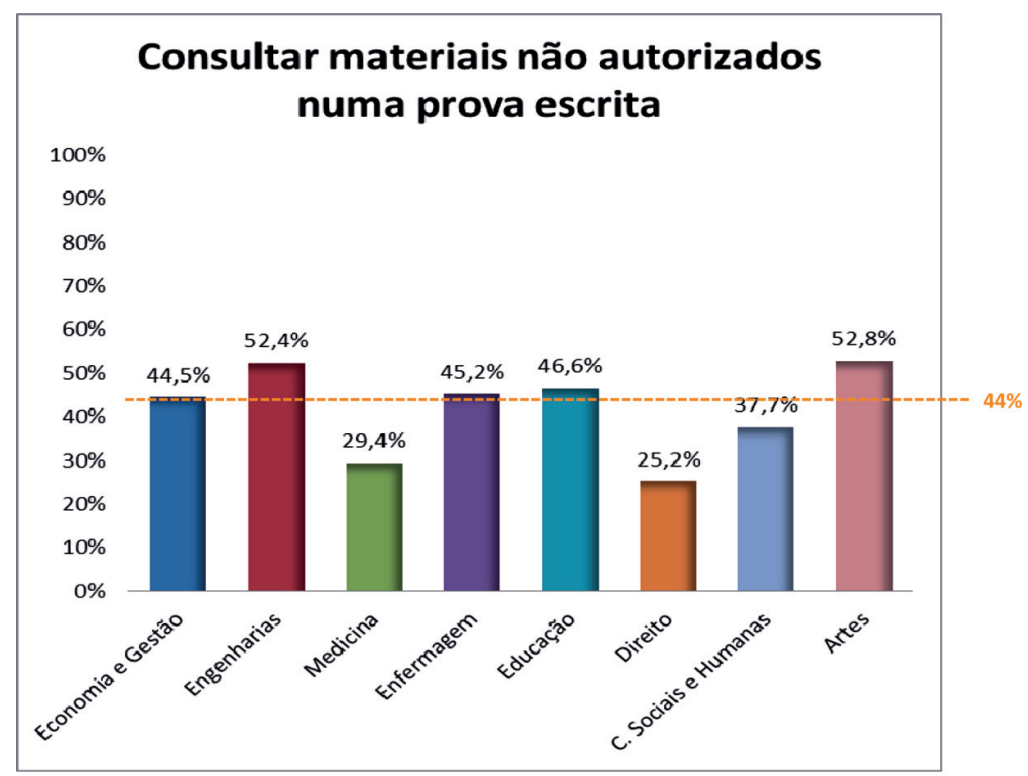

Gráfico 3. Predisposição para Consultar materiais não autorizados numa prova escrita (comparação por área científica)

No caso da fraude cometida em trabalhos individuais ou de grupo, as Engenharias destacam-se como a área científica onde os alunos revelam maior predisposição para Inventar dados, assim como para Copiar informação da Internet. No caso da cópia de trabalhos da Internet, juntam-se também a Medicina e a Economia e Gestão como áreas com alunos mais propensos a cometer esta fraude, ao contrário da área da Educação, na qual os alunos revelam o nível mais baixo de predisposição para copiar trabalhos da Internet. Os Gráficos 4 e 5 apresentam os resultados comparativos para estas duas formas de fraude cometida em trabalhos. 


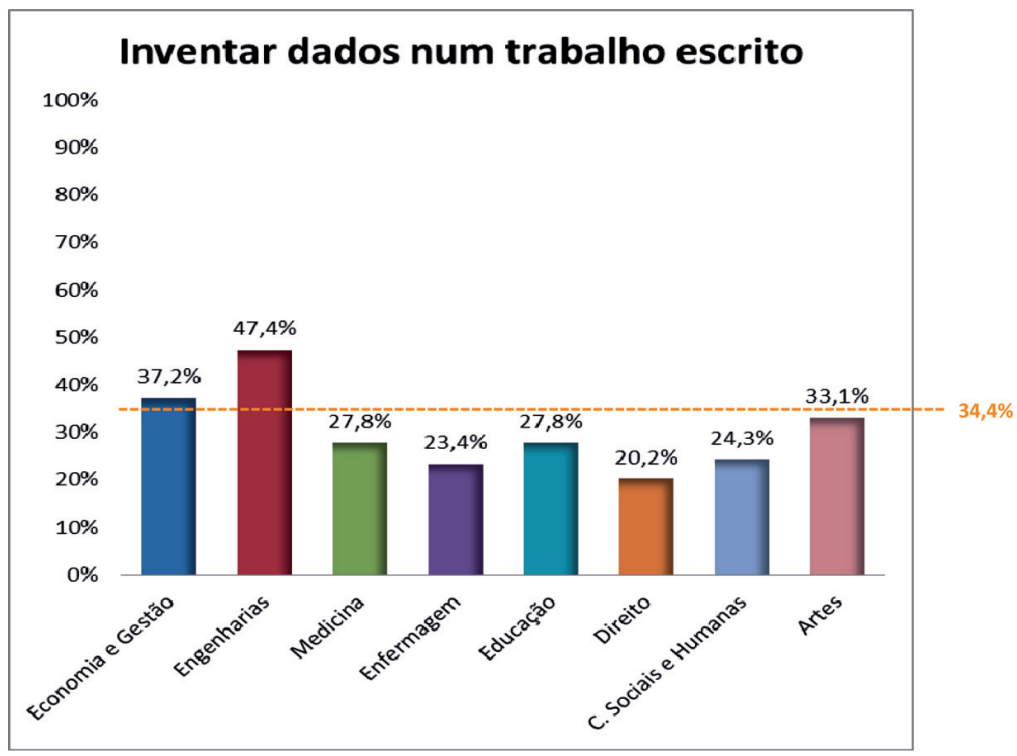

Gráfico 4. Predisposição para Inventar dados num trabalbo escrito (comparação por área científica)

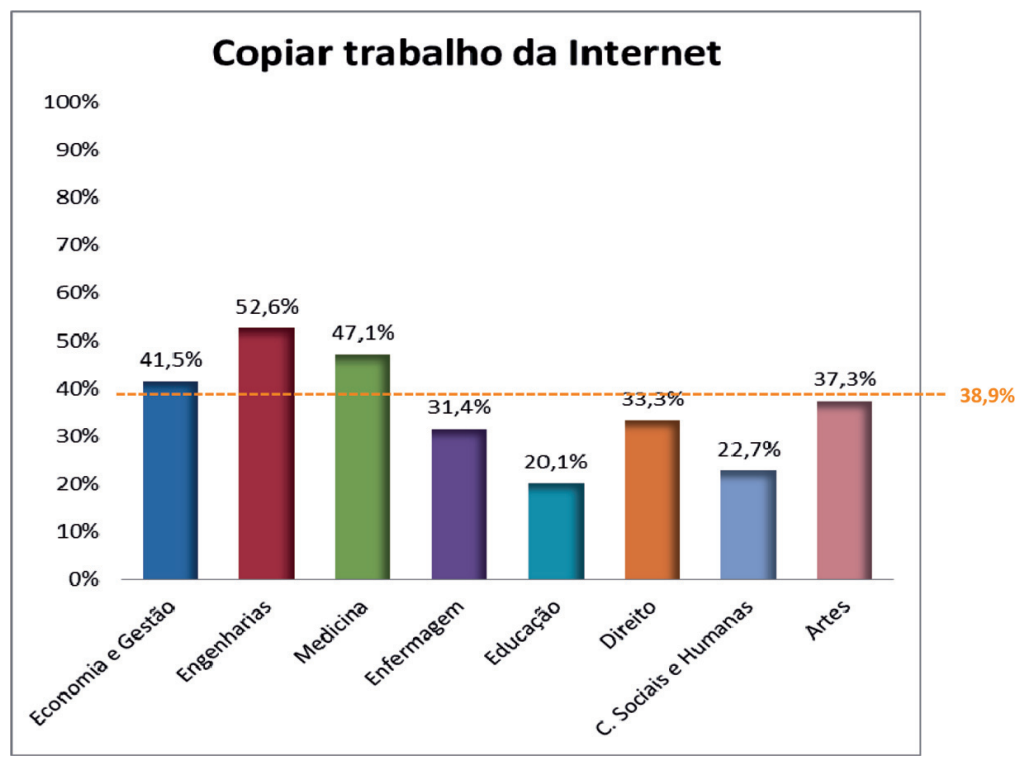

Gráfico 5. Predisposição para Copiar trabalho da Internet (comparação por área científica) 
Para uma análise mais detalhada, apresentam-se na Tabela 8 as percentagens de alunos que, em cada área científica, admitiram que fariam o mesmo que a personagem fictícia em cada uma das 13 práticas de fraude simuladas. Os dados confirmam uma maior predisposição dos alunos de todas as áreas para assumirem práticas passivas de facilitação da fraude do que práticas ativas de fraude em nome próprio. A compra de trabalhos também se confirma como uma prática genericamente repulsiva, embora não tão repulsiva como a venda.

\begin{tabular}{|c|c|c|c|c|c|c|c|c|}
\hline & \multicolumn{8}{|c|}{$\begin{array}{l}\text { Faria o mesmo? } \\
\text { "Sim" }\end{array}$} \\
\hline & 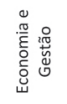 & 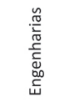 & 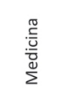 & 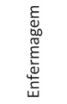 & 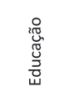 & 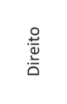 & 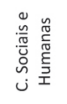 & $\underset{\frac{W}{4}}{\frac{W}{4}}$ \\
\hline $\begin{array}{l}\text { Apresentar o mesmo trabalho em diferentes } \\
\text { disciplinas }\end{array}$ & $72,1 \%$ & $81,2 \%$ & $85,0 \%$ & $72,4 \%$ & $66,8 \%$ & $54,3 \%$ & $62,8 \%$ & $71,8 \%$ \\
\hline Fornecer respostas a um colega num exame & $62,2 \%$ & $64,3 \%$ & $70,9 \%$ & $73,0 \%$ & $67,1 \%$ & $51,3 \%$ & $66,7 \%$ & $66,5 \%$ \\
\hline $\begin{array}{l}\text { Permitir que um colega partilhe a autoria formal de } \\
\text { um trabalho sem ter participado nele }\end{array}$ & $64,7 \%$ & $67,8 \%$ & $69,5 \%$ & $63,4 \%$ & $57,8 \%$ & $50,0 \%$ & $38,8 \%$ & $57,5 \%$ \\
\hline Copiar respostas de um colega numa prova escrita & $49,9 \%$ & $53,1 \%$ & $45,1 \%$ & $63,0 \%$ & $55,0 \%$ & $38,1 \%$ & $55,1 \%$ & $55,2 \%$ \\
\hline $\begin{array}{l}\text { Emprestar a colegas trabalho realizado por si próprio } \\
\text { para que estes apresentem como seu }\end{array}$ & $52,9 \%$ & $60,3 \%$ & $51,2 \%$ & $52,0 \%$ & $46,9 \%$ & $40,1 \%$ & $59,5 \%$ & $46,2 \%$ \\
\hline $\begin{array}{l}\text { Consultar materiais não autorizados numa prova } \\
\text { escrita }\end{array}$ & $44,5 \%$ & $52,4 \%$ & $29,4 \%$ & $45,2 \%$ & $46,6 \%$ & $25,2 \%$ & $37,7 \%$ & $52,8 \%$ \\
\hline Copiar trabalho da Internet & $41,5 \%$ & $52,6 \%$ & $47,1 \%$ & $31,4 \%$ & $20,1 \%$ & $33,3 \%$ & $22,7 \%$ & $37,3 \%$ \\
\hline Obter a colaboração de familiar & $42,3 \%$ & $43,5 \%$ & $30,3 \%$ & $36,3 \%$ & $31,7 \%$ & $30,8 \%$ & $30,4 \%$ & $37,2 \%$ \\
\hline Inventar dados num trabalho escrito & $37,2 \%$ & $47,4 \%$ & $27,8 \%$ & $23,4 \%$ & $27,8 \%$ & $20,2 \%$ & $24,3 \%$ & $33,1 \%$ \\
\hline Plágio autorizado do trabalho de um colega & $32,2 \%$ & $38,1 \%$ & $28,9 \%$ & $29,1 \%$ & $25,0 \%$ & $24,4 \%$ & $21,2 \%$ & $27,9 \%$ \\
\hline $\begin{array}{l}\text { Vender aos colegas trabalhos realizados por si } \\
\text { próprio }\end{array}$ & $28,8 \%$ & $37,8 \%$ & $19,4 \%$ & $17,9 \%$ & $12,6 \%$ & $20,1 \%$ & $18,5 \%$ & $29,9 \%$ \\
\hline $\begin{array}{l}\text { Não participar em trabalho de grupo, beneficiando } \\
\text { da nota coletiva }\end{array}$ & $24,0 \%$ & $29,9 \%$ & $17,0 \%$ & $20,0 \%$ & $14,0 \%$ & $14,7 \%$ & $13,0 \%$ & $21,8 \%$ \\
\hline Comprar trabalho a colega & $16,2 \%$ & $17,2 \%$ & $7,2 \%$ & $9,0 \%$ & $7,5 \%$ & $7,2 \%$ & $6,8 \%$ & $11,9 \%$ \\
\hline
\end{tabular}

Tabela 8. Predisposição para cometer Fraude Académica (por área científica) 
Os resultados sugerem alguns comportamentos curiosos. Por exemplo, no caso já discutido da dualidade entre, por um lado, aproveitar uma nota coletiva dada a um trabalho de grupo no qual não se participou e, por outro, aceitar que um colega assuma a autoria formal de um trabalho de grupo nessas circunstâncias, os dados confirmam a tendência geral de maior disponibilidade para facilitar a fraude do que para cometê-la. No entanto, a distância entre as posições ativa e passiva é maior na Medicina (onde as posições distam 52,5), que tem a maior predisposição ativa (69,5\%), e menor nas Ciências Sociais e Humanas (onde as posições distam 25,8), que tem a menor predisposição ativa (13\%). As Engenharias registam uma alta posição ativa $(67,8 \%)$, mas também a mais alta posição passiva (29,9\%), tal como também acontece no caso do plágio autorizado pelo trabalho de um colega, onde as posições ativa de plágio e passiva de empréstimo são as maiores entre os alunos estudados (60,3\% e 38,1\%, respetivamente). Haverá, porventura, nas Engenharias, uma cultura ou sistemas de avaliação que favorecem, entre os alunos, a troca de trabalhos entre si.

Já no caso de copiar por um colega numa prova escrita, a Enfermagem regista as posições ativa e passiva mais altas de todas as áreas científicas (63\% e $73 \%$, respetivamente), com menor distância entre elas, o que pode sugerir a existência de uma cultura razoavelmente disseminada de cópia entre colegas durante os exames nos cursos de Enfermagem. Mais uma vez a Medicina apresenta a maior distância entre posições, sendo que a passiva é a segunda mais alta (70,9\%). Isto pode significar que os alunos de Medicina estão motivados para facilitar a fraude, mas existirá porventura uma cultura de pudor interpares, enraizada nos códigos de ética que fundam a disciplina, que os inibe de aproveitar plenamente essa disponibilidade.

A área de Direito regista, em geral, os níveis mais baixos de predisposição dos alunos para cometerem fraude académica, quer ativa 
de apropriação, quer passiva de facilitação. Talvez isto se justifique pelas características próprias desta área científica, onde o respeito pela norma coletiva faz parte dos próprios conteúdos substantivos ensinados, o que poderá gerar um comportamento consonante com a doutrina estudada ou provocar um extremo pudor em admitir a possibilidade de praticar uma transgressão.

Por fim, destaca-se também a área da Educação como aquela onde é aparentemente mais repulsiva a venda de trabalhos ou a cópia de trabalhos da Internet, embora $67,1 \%$ destes alunos admitam que forneceriam respostas a um colega durante uma prova escrita e $57,8 \%$ admita aceitar que um colega se juntasse como coautor de um trabalho no qual não participou. Talvez subjacente a este resultado esteja a existência, entre os alunos da área de Educação, de um critério de admissibilidade da fraude apenas quando existam relações de cumplicidade entre colegas.

\subsection{O Indicador de Predisposição para a Fraude (IPF)}

A forma como foi construído o questionário apresentado aos alunos neste estudo permite extrair, a partir das respostas obtidas, indicadores agregados de preferências ou predisposições individuais. Um desses indicadores é o IPF (Indicador de Predisposição para a Fraude), o qual permite avaliar, em termos agregados, a propensão de cada aluno para cometer fraude. O IPF de cada aluno é calculado com base no número de vezes que ele respondeu positivamente à pergunta sobre se faria o mesmo que a personagem fictícia em cada cenário de fraude. Embora os cenários incluíssem 13 práticas (o que implicaria uma escala de 0 a 13), para facilitar a análise a escala do IPF sofreu uma transformação linear para ter uma variação entre 0 e 10, sendo que quanto maior for o IPF, maior será a propensão do aluno para cometer fraude académica. 
Assim, numa escala de 0 a 10, o IPF da amostra total de alunos em Portugal é de $\mathbf{4}, \mathbf{1 9}^{15}$. Este número, isolado, não diz muito. Mas revela-se interessante em análises comparativas, sendo especialmente útil para avaliar os determinantes da propensão para a fraude, permitindo uma análise cruzada entre o IPF de cada aluno e as suas opiniões e características individuais. Para a amostra total, o IPF é significativamente maior $^{16}$ :

- nos homens (IPF 4,66) do que nas mulheres (IPF 3,89)

- nos alunos cujo percurso pré-universitário foi maioritariamente feito em escolas privadas (IPF 4,44) do que em escolas públicas (IPF 4,17)

- nos alunos cujo curso que escolheram não foi a primeira opção (IPF 4,39) do que naqueles que foi a primeira escolha (IPF 4,14)

- nos alunos que já reprovaram em alguma disciplina (IPF 4,45 ) do que nos que não reprovaram (IPF 3,73)

- nos alunos com menor média

- nos alunos com mais inscrições no ensino superior

- nos alunos dirigentes associativos

- nos alunos que dizem não existir regulamento disciplinar na sua escola (IPF 4,59) do que naqueles que reconhecem existir regulamento disciplinar (IPF 4,04)

- nos alunos que, reconhecendo existir regulamento disciplinar na sua escola, não o leram (IPF 4,27) do que naqueles que o leram (IPF 3,53)

15 A robustez preditiva do IPF como indicador da propensão para cometer fraude parece ser confirmada pelo facto dele se revelar significativamente maior entre os alunos que consideram a fraude aceitável em determinadas circunstâncias (IPF 5,58$)$ do que entre aqueles que a consideram inaceitável em qualquer circunstância. (IPF 2,95) (teste t 43,638, p-value 0,000).

16 Os resultados dos testes estatísticos estão incluídos no ANEXO 4.2. 
- nos alunos que percecionam maior frequência de fraude no seu curso

- nos alunos cujos pais têm maior grau de escolaridade

- nos alunos cujos agregados familiares têm rendimentos mais elevados

Os dados revelam que a predisposição para a fraude é maior nos homens do que nas mulheres. Este resultado poderá estar relacionado com a forma como o poder é desigualmente distribuído na sociedade. Talvez o homem, que por regra está mais investido de poder que a mulher, tenha adquirido um sentimento de maior invulnerabilidade perante a vigilância da sua conduta e de maior impunidade perante a denúncia dos seus atos, o qual alimenta uma predisposição inconsciente para cometer a ação transgressiva.

Destaca-se também uma maior propensão à fraude em alunos que fizeram percursos pré-universitários em escolas privadas, e cujos pais têm maior grau de escolaridade e auferem maiores rendimentos. Este perfil pode indiciar a predisposição para a fraude como resposta a uma pressão social e familiar para alcançar o êxito que os pais também alcançaram. Essa pressão para o êxito, exercida explicitamente pelo contexto ou autoinfligida pelo aluno, poderá precipitar um comportamento fraudulento a fim de cumprir as expectativas pessoais e familiares.

A relação do aluno com a instituição e com o curso também parece ter um papel decisivo na predisposição para a fraude. Por um lado, os alunos que frequentam um curso que não foi a sua primeira escolha poderão ter uma relação mais desinteressada com os conteúdos estudados, sentindo-se descomprometidos e desobrigados moralmente perante a instituição. Por outro lado, o aluno que não sabe da existência ou nunca leu o regulamento disciplinar ou académico da instituição é também um aluno menos implicado institucionalmente e por isso porventura mais propenso à fraude. 
Saliente-se ainda que os melhores alunos, com média mais alta e que não reprovaram, tendem a ser menos propensos à fraude, o que sugere que as classificações dos alunos não são tendencialmente beneficiadas pela prática fraudulenta. Curiosamente, à medida que a predisposição para cometer fraude aumenta, também aumenta a frequência com que se perceciona a ocorrência de fraude no contexto escolar, o que sugere um processo de projeção ou de legitimação inconsciente da fraude cometida.

Quando comparadas as diferentes áreas científicas, verifica-se que as Engenharias e a Economia e Gestão registam um IPF acima da média, enquanto o Direito regista o IPF mais baixo, tal com seria de esperar a partir da análise detalhada da predisposição para cometer cada uma das práticas estudadas. O Gráfico 6 apresenta os resultados para as oito áreas científicas.

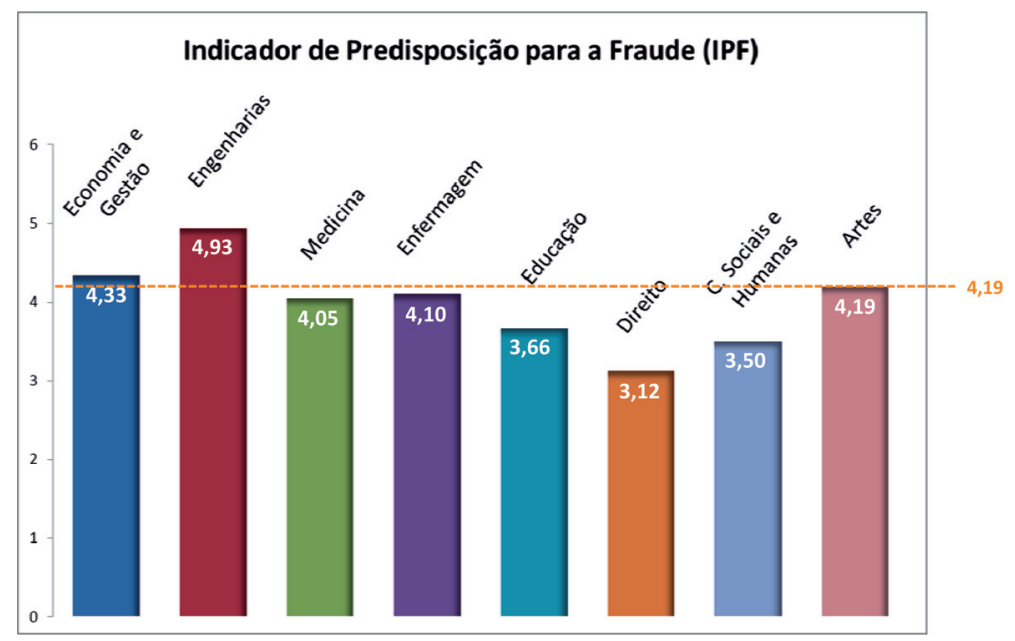

Gráfico 6. Indicador de Predisposição para Fraude (IPF)

Como análise complementar, pode subdividir-se o IPF num indicador de predisposição para a fraude ativa (IPF ATIVA) e num 
indicador de predisposição para a fraude passiva (IPF PASSIVA), distinguindo, entre as 13 práticas avaliadas, as 9 práticas ativas de apropriação do trabalho realizado por outro (que visam beneficiar a classificação académica do próprio agente da ação) e as 4 práticas passivas de facilitação da apropriação (que visam beneficiar a classificação académica de outro). Nestes termos, eis como podem ser agrupadas as práticas de fraude:

\begin{tabular}{l}
$\begin{array}{c}\text { Práticas de Fraude Ativa } \\
\text { (APROPRIAÇÃO) }\end{array}$ \\
\hline Apresentar o mesmo trabalho em diferentes disciplinas \\
Copiar respostas de um colega numa prova escrita \\
Consultar materiais não autorizados numa prova escrita \\
Copiar trabalho da Internet \\
Obter a colaboração de familiar \\
Inventar dados num trabalho escrito \\
Plágio autorizado do trabalho de um colega \\
Não participar em trabalho de grupo, beneficiando da \\
nota coletiva
\end{tabular}

Práticas de Fraude Passiva
(FACILITAÇÃO)

Ao distinguir as práticas ativas das práticas passivas constata-se que existe uma diferença significativa entre as predisposições dos alunos para cometerem as primeiras e as suas predisposições para cometerem as segundas. Na amostra total, o IPF ATIVA médio é de 3,83 e o IPF PASSIVA médio é de 5,14, o que evidencia uma maior disponibilidade dos alunos para facilitarem a apropriação do que para se apropriarem do trabalho alheio em benefício próprio. Quando analisadas e comparadas as oito áreas científicas, este padrão mantém-se consistentemente significativo, tal como pode ser observado no Gráfico 7. 


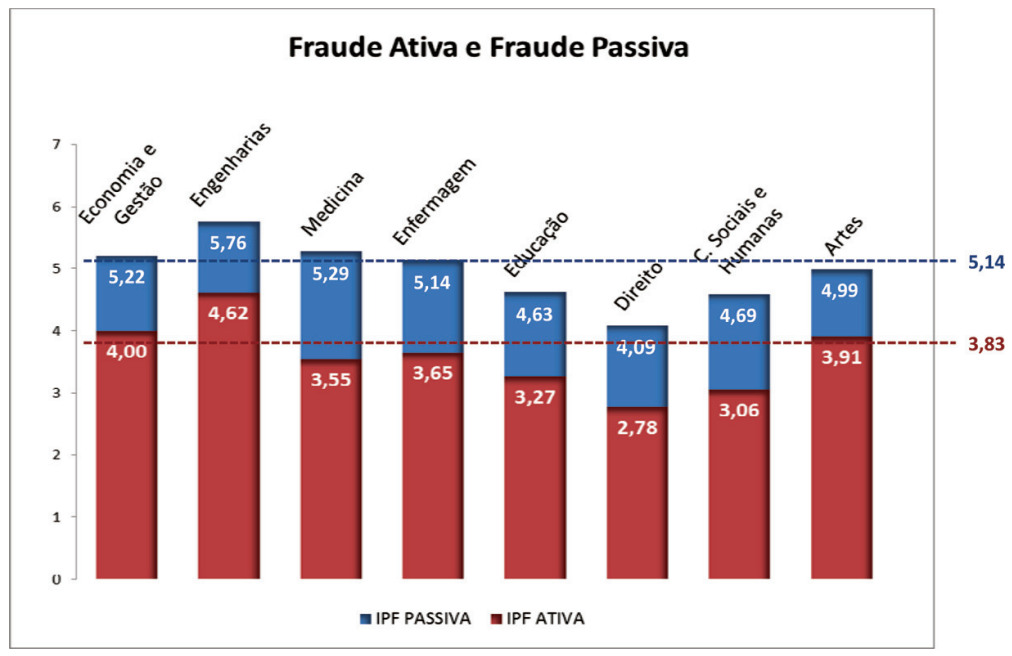

Gráfico 7. Predisposição para a Fraude Ativa e a Fraude Passiva

Em todas as áreas, os alunos revelam maior predisposição para facilitar do que para cometer a fraude com benefício académico próprio. Mesmo no caso das Artes, onde essa diferença é menor, ela mantém-se significativa. E no caso da Medicina, onde ela é maior, permite perceber uma propensão acima da média para a fraude passiva por parte destes alunos. Os resultados sinalizam assim a transversalidade de uma cultura de grande tolerância à fraude e de aversão ao risco, preferindo o envolvimento solidário na prática do que o protagonismo da iniciativa.

Em síntese, é de salientar que os melhores alunos são menos propensos a cometer fraude académica, diminuindo o IPF à medida que a média aumenta. Também é menor a predisposição dos que conhecem os regulamentos disciplinares, um instrumento de política institucional que se mantém fundamental para proteção dos bons alunos. Os dados sugerem também que as instituições poderiam beneficiar de políticas ativas de integração e acompanhamento dos alunos - especialmente aqueles que não ingressaram na sua pri- 
meira escolha -, valorizando o seu comprometimento com a escola e estimulando o seu interesse pelos conteúdos lecionados. Mas a fraude é um fenómeno coletivo e cultural e não deve ser combatido com medidas isoladas e de alcance estritamente individual. $\mathrm{O}$ envolvimento institucional dos dirigentes, professores, funcionários e alunos, ainda parece ser a forma mais eficaz e duradoura de resposta à prática académica desviante.

\subsection{O Indicador de Predisposição para a Denúncia (IPD)}

A partir das respostas obtidas é também possível calcular o IPD (Indicador de Predisposição para a Denúncia), um indicador que permite avaliar a propensão dos alunos para denunciarem a fraude observada. O IPD de cada aluno corresponde ao número de vezes que respondeu que denunciaria a situação caso tivesse conhecimento dela em cada um dos nove cenários de fraude apresentados. Neste caso, não se distingue a posição ativa da posição passiva, mas apenas os cenários de fraude que as incluem, por isso o número de respostas varia entre 0 e 9. Para facilitar a análise, foi transformada a escala para que, tal como o IPF, o IPD varie entre 0 e 10 , sendo que quanto maior for o IPD maior será a propensão do aluno para denunciar a fraude académica que observe.

Assim, numa escala de 0 a 10, o IPD da amostra total de alunos em Portugal é de $\mathbf{0 , 5 8 ^ { 1 7 }}$. Trata-se de um valor muito baixo que revela uma cultura de ocultação da fraude e inibição da denúncia, porventura explicada por um cultura académica de contraditória

17 Tal como no IPF, também o IPD apresenta diferenças estatisticamente significativas entre os alunos que consideram a fraude aceitável em determinadas circunstâncias (IPD 0,35) e aqueles que a consideram inaceitável em qualquer circunstância. (IPD 0,84) (teste t 12,436, p-value 0,000), o que é consistente com a intenção teórica deste indicador. 
condenação moral da denúncia, baseada em redes de cumplicidade e de reciprocidade interpares. Quando analisado à luz do perfil dos alunos, o IPD é, para a amostra total, significativamente maior ${ }^{18}$ :

- nos alunos com maior média

- nos alunos que reprovaram a menos disciplinas

- nos alunos com menos inscrições no ensino superior

- nos alunos que, reconhecendo existir regulamento disciplinar na sua escola, já o leram (IPD 0,93 ) do que aqueles que não o leram (IPD 0,48)

- nos alunos cuja mãe tem menor grau de escolaridade

Os resultados sugerem que a propensão para a denúncia, embora sempre baixa, é significativamente maior nos melhores alunos e naqueles que frequentam há menos tempo o ensino superior, revelando o peso da cultura organizacional e da cultura de pares na normalização de uma determinada cultura de fraude. Se a predisposição para a denúncia é maior à chegada ao ensino superior e se diminui à medida que os alunos se vão integrando nas instituições, o convívio com práticas de fraude baseadas na solidariedade entre pares legitima e naturaliza aquelas formas de fraude que poderão beneficiar a todos. Já a maior aversão dos melhores alunos à fraude académica, que torna a opção pela transgressão uma prática inaceitável e condenável, pode ser explicada como reflexo de um percurso escolar mais comprometido com o curso e com a instituição.

Como seria de esperar, os alunos que já leram o código disciplinar da sua instituição têm uma predisposição maior do que os outros para denunciar situações de fraude. Mais do que o efeito pedagógico que pode ter a leitura do código, será porventura a predisposição do aluno para o cumprimento de normas que o leva a lê-lo. Estes

18 Os resultados dos testes estatísticos estão incluídos no ANEXO 4. 
alunos são naturalmente mais comprometidos com as regras da instituição, têm um interesse evidente em conhecer as normas e estão porventura mais disponíveis para cumpri-las.

Por fim, é curioso verificar o efeito de favorecimento da denúncia que o grau de escolaridade mais baixo da mãe pode ter no aluno. O papel da mãe como educadora é ainda fundamental na sociedade portuguesa e não é de estranhar que exerça um efeito importante na estruturação do comportamento moral do aluno. Neste caso, o grau de escolaridade mais baixo da mãe pode indiciar uma história de vida mais marcada pela necessidade de exigir justiça e de reivindicar direitos sociais em contexto profissional e comunitário. Esta exigência de tratamento igualitário pode provocar uma maior intolerância perante o abuso e a fraude, mais acessível a quem tem mais poder e quase sempre geradores de maiores desigualdades que prejudicam quem é à partida socialmente mais desfavorecido. A influência deste modelo de comportamento sobre um filho pode refletir-se na sua intolerância, enquanto aluno, perante a fraude cometida pelos colegas.

A análise do IPD por área científica confirma a baixa propensão generalizada dos alunos para denunciar a fraude académica. No entanto, é possível observar que as áreas de Direito e Educação se destacam com IPD médios mais altos, enquanto as Engenharias, a Medicina e a Economia e Gestão apresentam IPD médios mais baixos. Estas diferenças sugerem que poderá existir de facto uma influência, mesmo que ligeira, dos conteúdos substantivos de cada área de estudo na cultura de tolerância ou intolerância à fraude por parte dos alunos. O Gráfico 8 apresenta os resultados do IPD por área científica. 


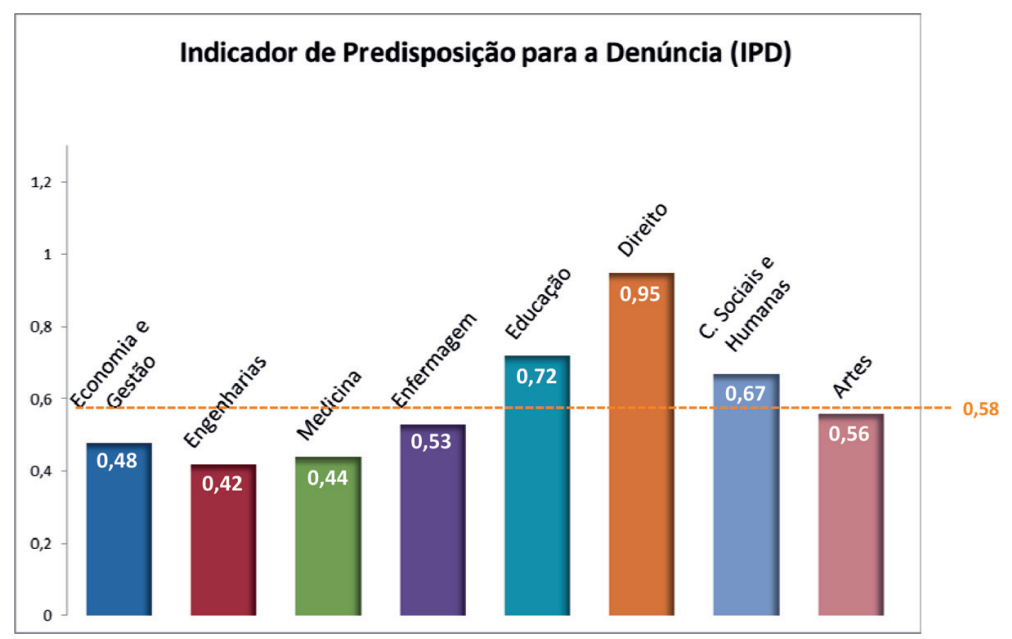

Gráfico 8. Indicador de Predisposição para a Denúncia (IPF)

Independentemente das diferenças entre áreas científicas, todos os resultados obtidos com o IPD confirmam a existência de uma cultura transversal de elevada tolerância à fraude entre os alunos portugueses. As relações de cumplicidade afetiva ou académica interpares criam um vínculo moral mais relevante do que a relação individual com a verdade, com a justiça da avaliação ou com a instituição de ensino. Este traço típico de uma sociedade onde predominam práticas sociais de entreajuda constitui um obstáculo à eficácia de qualquer política ativa de combate e punição da fraude. Não podendo nunca abdicar ou deixar de incentivar a denúncia como forma de deteção da fraude, é provavelmente mais eficaz uma política de combate baseada na dissuasão e na ameaça punitiva. Os meios repressivos poderão ser, no entanto, também geradores de respostas coletivas que aprofundam o descompromisso moral entre os alunos e a instituição. É neste equilíbrio fino entre punição e sensibilização que porventura se encontrará a melhor solução, necessariamente adaptada às condições materiais e humanas de cada contexto académico. 


\subsection{Os motivos para cometer fraude}

Além da opinião sobre a fraude académica, sobre a sua gravidade e sobre a predisposição pessoal para cometê-la ou denunciá-la, foi também solicitado aos alunos portugueses que se pronunciassem sobre os motivos que poderão levar os alunos a cometerem fraude ao longo do seu percurso académico. Foi assim pedido que classificassem, numa escala de importância que variava entre 1 e 5, cada um de treze motivos potencialmente explicativos da prática fraudulenta. A Tabela 9 apresenta os resultados obtidos na amostra total de alunos inquiridos.

\begin{tabular}{|c|c|c|}
\hline & & $\begin{array}{l}\text { Importância média } \\
\qquad(1-5)^{*}\end{array}$ \\
\hline 1 & Assegurar o sucesso a uma disciplina à qual já se reprovou & 3,74 \\
\hline 2 & Carga de trabalho académico & 3,74 \\
\hline 3 & $\begin{array}{l}\text { Insegurança sobre a capacidade de alcançar o sucesso de outra } \\
\text { forma }\end{array}$ & 3,26 \\
\hline 4 & Hábito de uma conduta fraudulenta desde o ensino secundário & 3,16 \\
\hline 5 & Modalidades de avaliação & 3,09 \\
\hline 6 & Pouca relevância prática atribuída aos conteúdos curriculares & 2,92 \\
\hline 7 & Regularidade da prática fraudulenta entre colegas & 2,87 \\
\hline 8 & Passividade dos professores perante situações de fraude & 2,80 \\
\hline 9 & $\begin{array}{l}\text { Perceção de que a pena, no caso de ser descoberta a fraude, é } \\
\text { pouco significativa }\end{array}$ & 2,70 \\
\hline 10 & $\begin{array}{l}\text { Falta de conhecimento sobre qual deve ser a boa conduta } \\
\text { académica }\end{array}$ & 2,67 \\
\hline 11 & Competência pedagógica insuficiente dos professores & 2,67 \\
\hline 12 & Pressão competitiva entre os colegas & 2,57 \\
\hline 13 & Falta de debate sobre $\mathrm{o}$ assunto nas aulas com os professores & 2,53 \\
\hline
\end{tabular}

* Mínimo de 1 e máximo de 5.

Tabela 9. Motivos para cometer Fraude Académica 
Como pode ser observado, na opinião dos alunos, os motivos mais relevantes para cometer fraude são: assegurar o sucesso a uma disciplina à qual já se reprovou, a carga de trabalbo académico e a insegurança sobre a capacidade de alcançar o sucesso de outra forma. Estes motivos estão portanto relacionados com a pressão para o sucesso e os obstáculos que o impedem, quer sejam as características do curso ou a insegurança do aluno. Curiosamente, os motivos mais desvalorizados são a pressão competitiva entre os colegas e a falta de debate sobre o assunto nas aulas com os professores. Ou seja, o comportamento fraudulento é melhor explicado pela insegurança perante si mesmo do que por sentimentos competitivos em relação à vontade de superar os outros. A própria ausência de debate sobre a fraude com os professores não parece suficiente para legitimá-la. Por outro lado, as respostas tendem também a sugerir que a fraude poderá ser uma resposta à pressão exercida mais pelos métodos de avaliação, do que pelo insuficiente desempenho técnico e didático dos professores.

Quando analisadas as respostas para as diferentes áreas científicas, verifica-se uma tendência convergente na importância relativa atribuída aos motivos para cometer fraude. Apesar disso, os casos onde existem maiores diferenças de opinião sugerem contrastes ligeiros, mas porventura relevantes, entre contextos e culturas académicas de cada área. O Gráfico 9 apresenta a importância atribuída pelos alunos das oito áreas científicas a seis motivos potenciais para cometer fraude. 


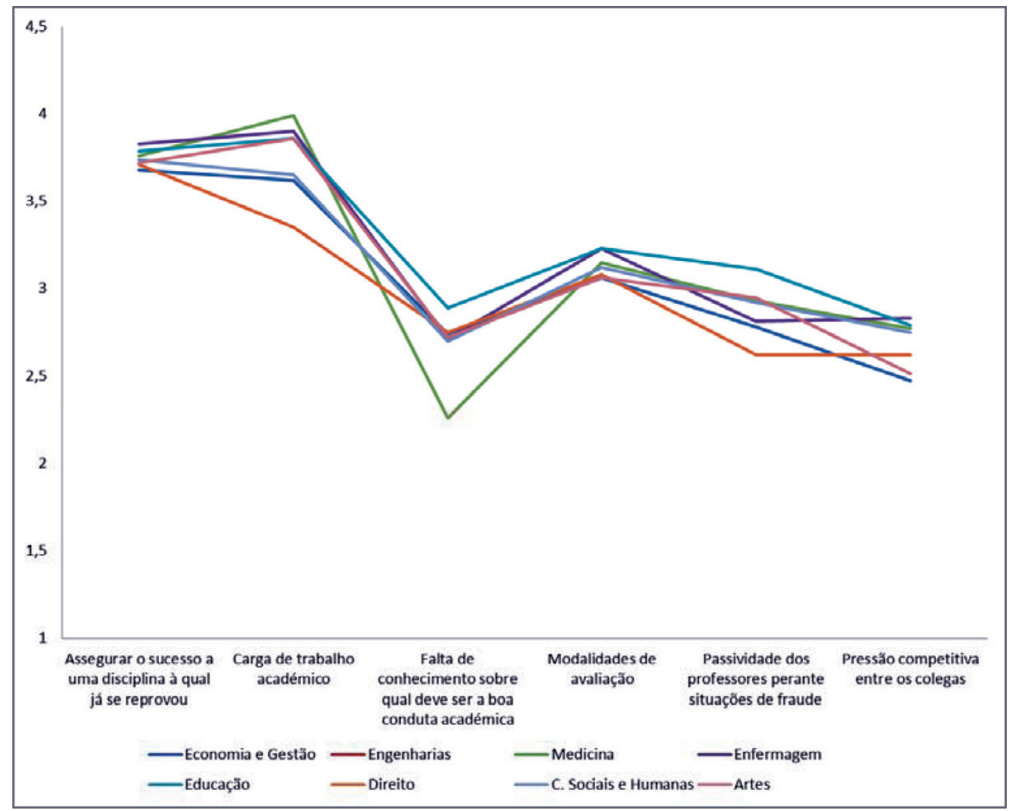

Gráfico 9. Motivos para cometer Fraude Académica (por área científica)

Como pode ser observado, os alunos de Medicina tendem a valorizar mais a carga de trabalho académico e menos o desconhecimento dos alunos sobre qual a boa conduta académica do que os restantes colegas de outras áreas. Ou seja, aparentemente a exigência dos cursos de Medicina representa um fator de pressão substancial sobre os alunos, genericamente bem esclarecidos, que desafia a sua integridade. Os alunos de Direito tendem a valorizar menos a carga de trabalho académico e a passividade dos professores como motivos que incentivam a fraude. Talvez estes alunos sintam que os seus professores têm uma intervenção afirmativa e eficaz na vigilância e prevenção da fraude. Curiosamente, os alunos da área de Educação parecem responsabilizar a sua ignorância sobre qual a boa conduta académica, queixando-se também das modalidades de avaliação e da passividade dos professores. 
Para compreender como pensam os alunos com predisposições morais diferentes, analisou-se também como a opinião sobre os motivos da fraude varia em função do IPF (Indicador de Predisposição para a Fraude) e do IPD (Indicador de Predisposição para Denúncia) ${ }^{19}$. Os resultados mostram que a propensão para cometer fraude (IPF) tende a ser maior à medida que o aluno também valoriza mais como motivadores da fraude a carga de trabalho académico, a necessidade de assegurar sucesso a uma disciplina à qual já se reprovou e as modalidades de avaliação. Ou seja, a predisposição para a fraude pode ser mais estimulada por meio da relação do aluno com a disciplina do que por causa da sua relação com a instituição ou a sua ignorância em relação aos princípios da boa conduta académica. Por outro lado, à medida que o aluno se revela mais predisposto a cometer fraude, também tende a desvalorizar como motivos para cometê-la, o hábito passado de fraude ou o desconhecimento sobre o que é a boa conduta académica, parecendo reforçar a ideia de que a relação com a disciplina é o fator prioritário de pressão para a fraude. Estes resultados sugerem uma responsabilização prioritária dos níveis de exigência pedagógica de cada curso como fator que estimula a fraude entre os alunos.

Quanto à relação dos motivos com o IPD, os resultados não destacam um motivo considerado mais relevante entre os alunos mais predispostos a denunciar a fraude. Em todo o caso, pode inferir-se uma ligeira tendência para os alunos se disporem mais a denunciar a fraude e a combatê-la (IPD mais elevado) quando reconhecem que a ignorância e a impunidade conduzem a práticas fraudulentas. Pode haver aqui uma sugestão de que o aluno se sente compelido a substituir-se à instituição no combate à fraude (porque a instituição não informa sobre ela, não a fiscaliza ou não a pune adequadamente).

19 Os resultados dos testes estatísticos estão incluídos no ANEXO 44. 
A compreensão do fenómeno da fraude académica e dos seus fundamentos psicológicos pode beneficiar da análise da existência de eventuais categorias de motivos para cometer fraude, segundo a importância que os alunos lhes atribuem. Para avaliar se os motivos estudados são agrupáveis em conjuntos homogéneos, procedeu-se à análise fatorial exploratória dos $\operatorname{dados}^{20}$. Esta análise sugeriu que, subjacente aos treze motivos estudados, existem 4 fatores que os agrupam e relacionam entre si. Os fatores identificados surgem organizados segundo um critério aparentemente relacionado com as diferentes instâncias com as quais o aluno se relaciona, distinguindo o círculo interior da relação consigo mesmo e com os colegas, de um círculo intermédio da relação com o curso, até ao círculo exterior da relação com a instituição. Assim, os fatores podem ser classificados nos seguintes termos:

\section{Fator 1 - Práticas pedagógicas (nível curricular) \\ Fator 2 - Cultura de fraude (nível institucional) \\ Fator 3 - Insegurança (nível individual) \\ Fator 4 - Ignorância (nível individual)}

Quando comparados estes quatro fatores - que agrupam quatro categorias de motivos - com o IPF, os resultados mostram que os alunos tendencialmente mais propensos a cometerem fraude tendem a valorizar mais as práticas pedagógicas (fator 1$)^{21}$ e a insegurança pessoal (fator 3$)^{22}$ como determinantes da fraude. Já os alunos com menor propensão a cometerem fraude tendem a valorizar mais a cultura de fraude (fator 2$)^{23}$ e a ignorância pessoal sobre o que é

\footnotetext{
20 Os resultados da Análise Fatorial Exploratória estão incluídos no ANEXO 4.5.

21 Coeficiente de Correlação de Spearman 0,176 (significativo ao nível de 1\%).

22 Coeficiente de Correlação de Spearman 0,077 (significativo ao nível de 1\%).

23 Coeficiente de Correlação de Spearman -0,076 (significativo ao nível de 1\%)
} 
a conduta adequada (fator 4$)^{24}$ como determinantes da fraude. Estes resultados sugerem que os alunos transgressores tendem a externalizar a culpa, responsabilizando a exigência porventura excessiva do curso que frequentam, enquanto os alunos menos transgressores tendem a internalizá-la, responsabilizando o ambiente favorável à fraude e a ignorância do aluno que transgride.

Relativamente à predisposição para denúncia, o IPD tende a aumentar à medida que aumenta a valorização, como motivadores da fraude, da cultura de fraude (fator 2$)^{25}$ e da ignorância pessoal sobre o que é a conduta adequada (fator 4$)^{26}$. Este resultado sugere que o aluno tende a substituir-se à instituição no combate à fraude, à medida que a reconhece menos capaz de fazê-lo com eficácia, quer seja na criação de uma cultura desincentivadora da fraude ou na educação dos alunos para uma prática académica exemplar.

Dificilmente existirá um único motivo para que um aluno decida, num dado momento, cometer fraude académica. Haverá porventura uma teia de causas que se cruzam nessa decisão, desde o contexto familiar, as referências socioculturais, as pressões sociais, o descomprometimento dos professores, a tolerância da instituição ou a própria insegurança do aluno. Em todo o caso, os resultados sugerem que talvez exista um contexto de carga porventura excessiva de trabalho que favorece a fraude, assim como um descrédito generalizado na eficácia da intervenção institucional para combatê-la. Embora estas causas não possam ser generalizadas, a análise da importância atribuída pelos alunos aos diferentes motivos oferece pistas de reflexão que merecem a atenção de todos os agentes envolvidos.

\footnotetext{
24 Coeficiente de Correlação de Spearman -0,15 (significativo ao nível de 1\%)

25 Coeficiente de Correlação de Spearman 0,06 (significativo ao nível de 1\%)

26 Coeficiente de Correlação de Spearman 0,11 (significativo ao nível de 1\%)
} 


\subsection{Os inibidores da fraude}

A eficácia de uma política institucional de combate à fraude académica depende, entre outros fatores, da qualidade do conhecimento de que se dispõe sobre o que a motiva, o que a facilita e o que a inibe. Neste sentido, foi solicitado aos alunos que se pronunciassem sobre os fatores que poderão desincentivar a prática fraudulenta, buscando desta forma aprofundar o conhecimento sobre quais os mecanismos e políticas potencialmente mais eficazes. Para o efeito, foi elaborada uma lista de quinze possíveis inibidores da fraude, incluindo medidas tão diversas como o agravamento das penas, o recurso a mecanismos de vigilância, a divulgação de códigos de conduta, o acompanhamento psicopedagógico ou a obrigatoriedade de provas orais ${ }^{27}$. Os alunos inquiridos deveriam então classificar cada uma das medidas segundo a sua importância para combater e inibir a prática de fraude, utilizando uma escala que varia entre 1 e 5. Dado pretender-se avaliar quais os inibidores potencialmente mais eficazes, foi também distinguida a importância média atribuída a cada medida pelos alunos que consideram a fraude aceitável em determinadas circunstâncias (portanto os potencialmente mais transgressores) e aqueles que a consideram inaceitável em qualquer circunstância ${ }^{28}$. A Tabela 10 apresenta os resultados obtidos para a amostra total.

\footnotetext{
27 Uma das quinze medidas, a "Diminuição do grau de complexidade das provas" é, na realidade, um falso inibidor, dado que a sua implementação, no limite, conduziria à extinção da própria situação que justifica a fraude: a avaliação. Portanto este item foi excluído da análise.

28 Quando comparadas as médias das importâncias atribuídas aos inibidores pelos alunos que consideram a fraude aceitável em determinadas circunstâncias (média 3,06) e os alunos que a consideram sempre inaceitável (média 2,74), o resultado revela que existe uma diferença estatisticamente significativa entre estes dois grupos de alunos ( $t$-Student 18,205, p-value 0.000). Este resultado confirma a relevância de se analisar, além da opinião geral, também as médias de respostas de cada um destes grupos de alunos.
} 


\begin{tabular}{|c|c|c|c|c|}
\hline & & \multicolumn{3}{|c|}{ Importância média } \\
\hline & & $\begin{array}{l}\text { TOTAL } \\
\text { [1-5] }\end{array}$ & $\begin{array}{l}\text { "Fraude é } \\
\text { Aceitável" }\end{array}$ & $\begin{array}{l}\text { "Fraude é } \\
\text { Inaceitável" }\end{array}$ \\
\hline 1 & Agravamento das penas para conduta académica fraudulenta & 3,40 & 3,15 & 3,70 \\
\hline 2 & Existência de uma relação de proximidade entre professores e alunos & 3,26 & 3,33 & 3,23 \\
\hline 3 & Impedir telemóveis ligados na sala onde se realizam exames & 3,19 & 2,95 & 3,46 \\
\hline 4 & $\begin{array}{l}\text { Utilização de mecanismos de vigilância e de deteção eletrónica de } \\
\text { fraude }\end{array}$ & 3,08 & 2,88 & 3,30 \\
\hline 5 & $\begin{array}{l}\text { Envolvimento dos estudantes na divulgação de boas práticas } \\
\text { académicas }\end{array}$ & 3,07 & 2,95 & 3,22 \\
\hline 6 & $\begin{array}{l}\text { Frequência de programas de desenvolvimento de competências } \\
\text { académicas }\end{array}$ & 3,04 & 2,99 & 3,12 \\
\hline 7 & Frequência de programas de apoio psicopedagógico & 2,99 & 2,91 & 3,09 \\
\hline 8 & $\begin{array}{l}\text { Garantia de anonimato na denúncia de comportamentos } \\
\text { fraudulentos dos colegas }\end{array}$ & 2,94 & 2,76 & 3,19 \\
\hline 9 & Divulgação de um Código de Conduta da escola & 2,77 & 2,51 & 3,04 \\
\hline 10 & $\begin{array}{l}\text { Entrega de uma declaração de autoria/originalidade dos trabalhos } \\
\text { apresentados para avaliação }\end{array}$ & 2,77 & 2,63 & 2,96 \\
\hline 11 & $\begin{array}{l}\text { Sessões de esclarecimento promovidas pela escola sobre a boa } \\
\text { conduta académica }\end{array}$ & 2,61 & 2,45 & 2,78 \\
\hline 12 & $\begin{array}{l}\text { Divulgação no ambiente escolar do nome dos alunos que praticaram } \\
\text { fraudes }\end{array}$ & 2,43 & 2,26 & 2,66 \\
\hline 13 & Frequência de disciplinas sobre Ética & 2,42 & 2,25 & 2,62 \\
\hline 14 & Existência de provas orais obrigatórias & 2,41 & 2,38 & 2,49 \\
\hline
\end{tabular}

Tabela 10. Inibidores da Fraude Académica

Os dados revelam que, segundo os alunos, os inibidores da fraude mais relevantes são o agravamento das penas para conduta académica fraudulenta e existência de uma relação de proximidade entre professores e alunos, logo seguidos de medidas preventivas e de fiscalização do comportamento. Quando analisada apenas a opinião dos alunos potencialmente mais transgressores (que consideram a fraude aceitável), verifica-se um reforço da valorização da relação de proximidade entre professores e alunos e 
do envolvimento dos alunos na instituição como fatores inibidores da prática fraudulenta. Talvez subjacente a esta opinião exista uma queixa quanto ao distanciamento relacional entre professor e aluno e entre instituição e aluno que as inovações pedagógicas institucionais parecem não ter ainda conseguido combater. No caso dos alunos que consideram a fraude inaceitável há uma clara valorização do reforço das respostas punitivas e dos mecanismos de vigilância, o que parece ser o reconhecimento, por parte destes alunos, de que ainda é insuficiente a aplicação destas medidas nas instituições de ensino superior.

Quanto aos inibidores menos relevantes, destacam-se a existência de provas orais obrigatórias, a frequência de disciplinas sobre Ética e a divulgação no ambiente escolar do nome dos alunos que praticaram fraudes. Ou seja, aparentemente as provas orais não impedem a fraude em outras instâncias de avaliação e por isso, na opinião dos alunos, não são um inibidor eficaz. Também a formação em ética parece desvalorizada como meio de sensibilização e desenvolvimento moral dos alunos. A divulgação pública do nome dos alunos transgressores não parece importante, talvez porque os alunos valorizam mais a liberdade do que a verdade ou porque simplesmente não acreditam que esta seja uma medida viável no contexto cultural das instituições que conhecem.

A análise das opiniões por área científica confirmam as tendências gerais, embora permita distinguir padrões de preferência entre algumas áreas. O Gráfico 10 apresenta a importância média atribuída pelos alunos de cada uma das oito áreas científicas a onze potenciais inibidores da fraude académica. 


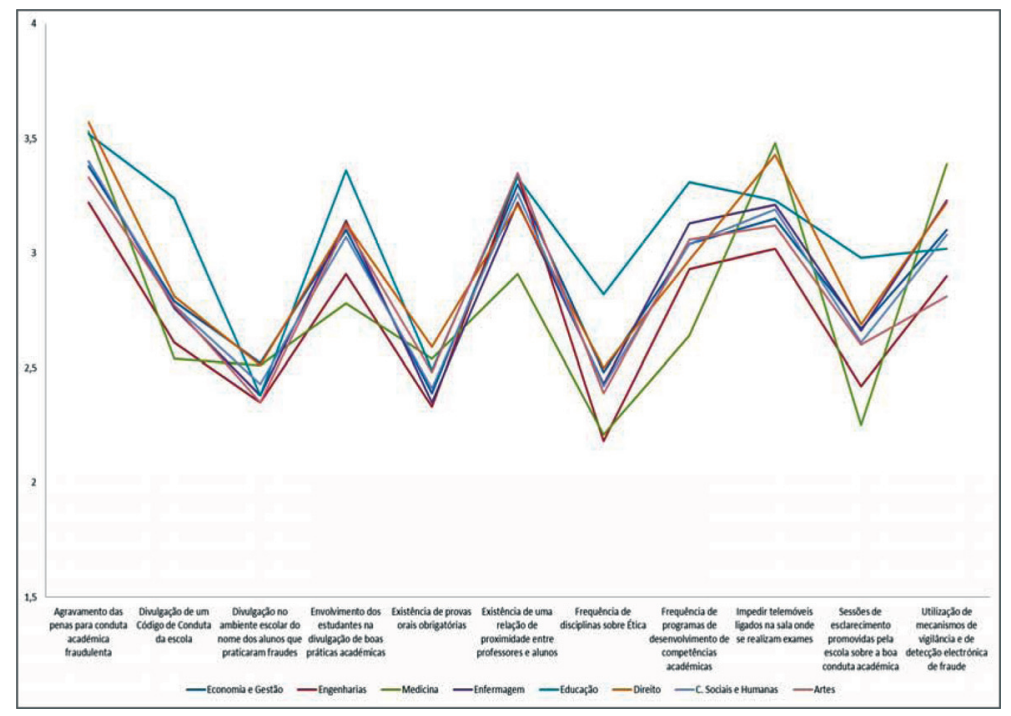

Gráfico 10. Inibidores da Fraude Académica (por área científica)

A análise comparativa revela algumas diferenças interessantes entre alunos de diferentes áreas científicas. Por exemplo, os alunos de Medicina parecem valorizar substancialmente mais os mecanismos de vigilância e controlo do que as medidas de formação e educação dos alunos enquanto meios de combate à fraude. Estes alunos também se destacam de todos os restantes por valorizarem menos a relação de proximidade com o professor como inibidor da fraude, o que pode explicar-se por essa relação já ser naturalmente próxima ou ser naturalmente distante. Contrariamente aos alunos de Medicina, os alunos da área de Educação valorizam, mais do que os outros, as medidas relacionadas com a formação dos alunos, com o seu envolvimento e desenvolvimento no contexto institucional, o que parece consistente com a filosofia subjacente aos conteúdos lecionados nesta área científica. Genericamente, os alunos das Engenharias tendem a atribuir importâncias mais baixas do que os colegas de outras áreas à maioria dos inibidores, o que parece 
evidenciar algum ceticismo relativamente à eficácia das medidas apresentadas, com exceção apenas no caso da relação de proximidade entre aluno e professor.

Como análise complementar, avaliou-se também como a opinião dos alunos sobre os inibidores varia em função do IPF (Indicador de Predisposição para a Fraude) e do IPD (Indicador de Predisposição para Denúncia) ${ }^{29}$. Tal como esperado, o IPF varia negativamente com a importância atribuída a quase todos os potenciais inibidores da fraude, com especial destaque para a desvalorização das iniciativas que visam educar e formar os alunos para a boa conduta académica. No entanto, os alunos potencialmente mais transgressores valorizam como inibidor a relação de proximidade entre professores e alunos, confirmando a importância das práticas pedagógicas personalizadas e evidenciando os perigos de um sistema de ensino baseado na quantidade e no afastamento entre os agentes ativos desse processo. Tal como esperado, o IPD varia positivamente com a importância atribuída a todos os potenciais inibidores da fraude, com especial destaque para iniciativas que promovam uma cultura institucional de intolerância à fraude que legitime e incentive a denúncia.

Tal como para os motivos que levam a cometer fraude, também no caso dos inibidores da fraude pode ser útil averiguar a existência de eventuais categorias de inibidores que formem conjuntos homogéneos de medidas agrupadas de acordo com a importância que os alunos lhes atribuem. Para o efeito, procedeu-se à análise fatorial exploratória dos dados ${ }^{30}$, a qual sugeriu que, subjacente aos catorze inibidores considerados, existem 3 fatores que os agrupam e rela-

29 Os resultados dos testes estatísticos estão incluídos no ANEXO 4.6.

30 Os resultados da Análise Fatorial Exploratória estão incluídos no ANEXO 4.7. 
cionam entre $\mathrm{si}^{31}$. O agrupamento dos inibidores parece ter como critério de diferenciação entre eles o tipo de estratégia de combate à fraude, podendo os fatores ser designados nos seguintes termos:

\section{Fator 1 - Estratégias de dissuasão \\ Fator 2 - Estratégias de informação \\ Fator 3 - Estratégias de apoio pedagógico}

A organização dos inibidores nestes três fatores sugere a existência de três eixos possíveis de organização das políticas de combate institucional à fraude. Um primeiro eixo que privilegia a criação e o desenvolvimento de mecanismos de dissuasão, baseados num sistema de denúncia e castigo da fraude académica. Um segundo eixo que privilegia a formação e a educação dos alunos sobre a boa conduta académica. E um terceiro eixo que privilegia a qualidade da relação pedagógica com o aluno, materializada em políticas de reforço da proximidade e do comprometimento do aluno com a instituição.

Em síntese, os resultados fornecem algumas pistas importantes para a reflexão e o desenho de políticas de combate à fraude. Apesar do caráter punitivo do agravamento das penas, valorizada como medida mais eficaz para inibir a fraude, destaca-se a relação de proximidade entre aluno e instituição como um elemento-chave para desincentivar a prática fraudulenta. Em relações de proximidade o compromisso moral entre as partes envolvidas é maior e a inibição mais eficaz, dado ser uma resposta ativa a um imperativo interior e não uma reação defensiva perante uma ameaça exterior. É curioso que os alunos tenham sinalizado tão claramente esta ideia, certamente fruto da consciência que têm do seu efeito, mas porven-

31 A mesma análise para as subamostras de alunos que consideram a fraude aceitável e alunos que a consideram inaceitável produziu resultado idêntico, sugerindo a universalidade da interpretação destes três fatores. 
tura também das carências que sentem na relação pedagógica que desenvolvem com os professores nos cursos que frequentam.

\subsection{Evolução das opiniões e predisposições}

A educação formal universitária pode exercer uma influência significativa na consolidação do sistema de valores pessoais dos alunos, porventura alinhando-o com as idiossincrasias próprias do campo de estudo, com as exigências do mercado de trabalho a que se destina, ou mesmo com a cultura específica de cada instituição ou grupo de docentes de referência. Neste sentido, procurou-se avaliar em que medida essa influência se manifesta nas perceções dos alunos relativas à fraude académica, analisando a evolução do seu pensamento ao longo do percurso formativo e eventual início da vida profissional. Para esse feito, foi solicitado aos alunos que responderam ao questionário em 2011 que, caso aceitassem participar novamente no futuro neste estudo, indicassem o seu contacto.

Os alunos que aceitaram participar de forma não anónima foram novamente contactados, desta vez por e-mail, para responderem a um questionário idêntico. Foram contactados 1036 alunos e a recolha de dados ocorreu entre 30/10/2013 e 15/03/2014. A amostra final fixou-se em 341 alunos. Destes, 52,4\% ainda eram alunos do ensino superior, $44,5 \%$ já tinham concluído o curso e 37,6\% tinham atividade remunerada ( $85,7 \%$ dos quais por conta de outrem). Relativamente à amostra do primeiro questionário, neste painel existem mais mulheres, correspondendo a $67,6 \%$ do total. Na avaliação da sua situação profissional atual ou a expectativa de situação profissional futura, $22,9 \%$ dos alunos considera que ela é melhor do que a dos colegas, enquanto $68 \%$ considera-a idêntica.

Tratando-se de um grupo de alunos com experiência significativa no ensino superior, questionou-se o seu grau de satisfação com 
quatro dimensões da sua vida académica. A partir dessas respostas foi possível construir um Indicador de Satisfação Académica (ISA) de cada aluno correspondente à média das suas respostas ${ }^{32}$. Em geral, estes alunos estão razoavelmente satisfeitos com a área científica que escolheram e com a instituição onde optaram por estudar. Como seria previsível no contexto económico atual, mostram-se mais insatisfeitos com as perspetivas de desenvolvimento de uma carreira profissional. A Tabela 11 apresenta a satisfação média dos alunos para cada uma dessas dimensões numa escala de 1 a 10.

\begin{tabular}{lc} 
& $\begin{array}{c}\text { Satisfação } \\
(1-10)\end{array}$ \\
\hline Relativamente à área de estudos que seguiu & 7,88 \\
Relativamente ao seu percurso escolar & 7,18 \\
$\begin{array}{l}\text { Relativamente à instituição onde adquiriu o seu grau de licenciatura/mestrado } \\
\text { integrado }\end{array}$ & 7,32 \\
$\begin{array}{l}\text { Relativamente às perspetivas de desenvolvimento de carreira que os seus estudos lhe } \\
\text { possibilitam }\end{array}$ & 6,70 \\
\hline \begin{tabular}{l} 
Indicador de Satisfação Académica (ISA) \\
\hline
\end{tabular}
\end{tabular}

Tabela 11. Satisfação Académica dos Alunos

Análises mais detalhadas do ISA sugerem que este indicador não varia de forma estatisticamente significativa com qualquer uma das variáveis demográficas destes alunos, o que significa que o seu grau de satisfação não dependerá do sexo, nem da idade, nem do contexto familiar. No entanto, o ISA diminui à medida que aumenta a ocorrência percecionada de fraude académica no contexto escolar e aumenta à medida que também aumenta a média curricular do

32 Esta agregação de quatro dimensões num único indicador é validada pela análise estatística dos dados. A análise fatorial exploratória confirmou a existência de apenas 1 fator (KMO 0.748 , sig. 0.000 , que explica $60,4 \%$ da variância) e a escala apresenta um Alpha de Cronbach de 0,779. 
aluno $^{33}$. Ou seja, a perceção da existência de fraude cometida pelos colegas diminui a satisfação geral dos alunos, sendo esta uma evidência do efeito psicológico negativo que uma cultura permissiva e negligente no combate à fraude académica também pode ter nos próprios alunos. Por outro lado, é de salientar que os melhores alunos são também alunos mais satisfeitos com as suas opções académicas.

\section{Perceções sobre a Prática de Fraude}

A evolução das perceções sobre as práticas de fraude revela uma ligeira tendência, embora estatisticamente significativa, para percecionar uma ocorrência mais baixa de fraude do que no passado, tal como pode ser observado na Tabela 12.

\begin{tabular}{lccc} 
& Em 2011 & Em 2013 & diferença \\
\hline Utilizar materiais não autorizados na realização de provas escritas & 3,27 & 3,09 & $-0,18^{* *}$ \\
\hline Copiar numa prova escrita pelas respostas de um colega & 3,19 & 3,05 & $-0,14^{* *}$ \\
\hline Deixar copiar respostas num exame & 3,02 & 2,83 & $-0,05$ \\
\hline $\begin{array}{l}\text { Assinar um trabalho de grupo sem ter colaborado na realização do } \\
\text { mesmo }\end{array}$ & 3,02 & 2,97 & $-0,19^{* *}$ \\
\hline Copiar partes de trabalhos de outros autores sem os citar & 2,90 & 2,68 & $-0,22^{* *}$ \\
\hline Copiar trabalhos de outros colegas & 2,81 & 2,60 & $-0,21^{* *}$ \\
\hline Copiar trabalhos da Internet & 2,72 & 2,49 & $-0,23^{* *}$ \\
\hline Apresentar trabalhos práticos com dados inventados & 2,09 & 1,96 & $-0,13^{* *}$ \\
\hline Apresentar o mesmo trabalho em várias disciplinas & 2,02 & 2,07 & 0,05 \\
\hline Comprar trabalhos académicos fora da escola & 1,71 & 1,59 & $-0,12^{* *}$ \\
\hline Comprar trabalhos a outros colegas & 1,61 & 1,49 & $-0,12^{* *}$ \\
\hline Denunciar fraudes académicas cometidas por colegas & 1,34 & 1,33 & $-0,01$ \\
\hline
\end{tabular}

** significativo ao nivel de $1 \%$

Tabela 12. Evolução da Perceção sobre a Frequência das Práticas de Fraude Académica (2011-2013)

33 Coeficientes de Correlação de Spearman -0,117 com a frequência da fraude (significativo ao nível de 5\%) e 0,149 com a média curricular (significativo ao nível de $1 \%)$. 
Efetivamente, se for comparada, nestes alunos, a média da perceção de frequência destas práticas de fraude em $2011(2,47)$ com a média dessa perceção em 2013 (2,35), confirma-se a existência de uma diminuição estatisticamente significativa da incidência percecionada de fraude académica ${ }^{34}$. Isto pode significar que os alunos, à medida que avançam no seu percurso académico, tornam-se menos sensíveis em relação à observação da fraude ou que, por outro lado, poderão legitimar práticas que antes condenavam.

\section{Opiniões sobre a Gravidade da Fraude}

Quanto à gravidade da fraude, estes alunos tornaram-se mais críticos em relação a fraudes cometidas em trabalhos, tal como pode ser observado na Tabela 13. Este resultado sugere que à medida que se aproximam do fim do curso, a consciência da importância que a avaliação comparativa e justa de desempenhos pode ter na empregabilidade futura torna os alunos menos disponíveis para aceitar colegas que se "pendurem" no seu trabalho. Mas sugere também a necessidade de explorar melhor uma hipótese que já foi sugerida anteriormente. Ou seja, a aversão diferenciada dos alunos a um ou outro tipo de fraude tem também a ver com as práticas de avaliação diferenciadas ao longo dos percursos formativos. Os alunos parecem ser mais avessos às fraudes que constatam. Se numa fase inicial da sua formação, onde predominam as provas escritas, há uma perceção de que as fraudes ocorrem predominantemente na realização de provas escritas, numa fase posterior, quando os trabalhos individuais se tornam mais frequentes como instrumento de avaliação, impõe-se a perceção de que as fraudes ocorrem também nessa forma de avaliação. É por isso compreensível que os alunos se mostrem menos

34 t-Student 3,811 (p-value 0,000) 
tolerantes, numa fase mais avançada da sua formação académica, em relação às fraudes cometidas em trabalhos.

\begin{tabular}{|c|c|c|c|}
\hline & \\
\hline & $\begin{array}{l}\mathrm{Em} 2011 \\
(1-10)\end{array}$ & $\begin{array}{c}\operatorname{Em} 2013 \\
(1-10)\end{array}$ & diferença \\
\hline Comprar trabalho a colega & 8,83 & 8,64 & $-0,19$ \\
\hline Vender aos colegas trabalhos realizados por si próprio & 7,58 & 7,63 & 0,05 \\
\hline Obter a colaboração de familiar & 7,50 & 7,89 & 0,39 \\
\hline Plágio autorizado do trabalho de um colega & 7,37 & 7,87 & $0,5^{* *}$ \\
\hline Inventar dados num trabalho escrito & 7,22 & 7,75 & 0,53 \\
\hline Consultar materiais não autorizados numa prova escrita & 7,15 & 6,99 & $-0,16$ \\
\hline Copiar trabalho da internet & 7,07 & 7,67 & $0,6^{*}$ \\
\hline Copiar respostas de um colega numa prova escrita & 6,75 & 6,68 & $-0,07$ \\
\hline Não participar em trabalho de grupo, beneficiando da nota coletiva & 6,41 & 7,72 & $1,31 * *$ \\
\hline $\begin{array}{l}\text { Emprestar a colegas trabalho realizado por si próprio para que estes } \\
\text { apresentem como seu }\end{array}$ & 5,98 & 7,05 & $1,07^{* *}$ \\
\hline Fornecer respostas a um colega num exame & 5,88 & 6,17 & 0,29 \\
\hline Apresentar o mesmo trabalho em diferentes disciplinas & 4,49 & 5,58 & 1,09 \\
\hline $\begin{array}{l}\text { Permitir que um colega partilhe a autoria formal de um trabalho sem } \\
\text { ter participado nele }\end{array}$ & 4,46 & 6,31 & $1,85^{*}$ \\
\hline
\end{tabular}

Tabela 13. Evolução da Opinião sobre a Gravidade das Práticas de Fraude Académica (2011-2013)

É interessante notar que existe uma clara consistência na evolução destas opiniões, considerando mais graves as práticas concretas de falsa autoria e coautoria de trabalho, condenando tanto a sua forma ativa como a sua forma passiva, ou seja, tanto quem beneficia como quem a facilita. Haverá uma maior valorização do trabalho realmente realizado por cada um e uma defesa mais consciente do mérito, espelhada na condenação também maior da cópia de trabalhos descarregados da Internet. 


\section{Predisposições para Cometer e para Denunciar a Fraude}

Quando questionados se fariam o mesmo que as personagens fictícias descritas nos cenários de fraude, a tendência geral é para que a percentagem de alunos que responde afirmativamente seja menor. No entanto, as únicas diferenças estatisticamente significativas são a diminuição da predisposição dos alunos para fazer plágio autorizado do trabalho de um colega e para permitir que um colega partilhe a autoria formal de um trabalho sem ter participado nele, tal como apresentado na Tabela 14.

\begin{tabular}{lccc} 
& \multicolumn{3}{c}{ Faria o mesmo? “Sim" } \\
\cline { 2 - 3 } & Em 2011 & Em 2013 & diferença \\
\hline Apresentar o mesmo trabalho em diferentes disciplinas & $71,3 \%$ & $73,2 \%$ & $1,9 \%$ \\
\hline Fornecer respostas a um colega num exame & $68,9 \%$ & $65,3 \%$ & $-3,6 \%$ \\
\hline $\begin{array}{l}\text { Permitir que um colega partilhe a autoria formal de um trabalho sem } \\
\text { ter participado nele }\end{array}$ & $63,6 \%$ & $57,3 \%$ & $-6,3 \% * *$ \\
\hline Copiar respostas de um colega numa prova escrita & $48,4 \%$ & $43,1 \%$ & $-5,3 \%$ \\
\hline $\begin{array}{l}\text { Emprestar a colegas trabalho realizado por si próprio para que estes } \\
\text { apresentem como seu }\end{array}$ & $43,1 \%$ & $39,8 \%$ & $-3,3 \%$ \\
\hline Consultar materiais não autorizados numa prova escrita & $38,5 \%$ & $35,5 \%$ & $-3,0 \%$ \\
\hline Copiar trabalho da internet & $29,4 \%$ & $25,4 \%$ & $-4,0 \%$ \\
\hline Inventar dados num trabalho escrito & $27,9 \%$ & $28 \%$ & $0,1 \%$ \\
\hline Obter a colaboração de familiar & $26,3 \%$ & $23 \%$ & $-3,3 \%$ \\
\hline Plágio autorizado do trabalho de um colega & $24,6 \%$ & $18,6 \%$ & $-6 \% * *$ \\
\hline Vender aos colegas trabalhos realizados por si próprio & $21,3 \%$ & $21,7 \%$ & $0,4 \%$ \\
\hline Não participar em trabalho de grupo, beneficiando da nota coletiva & $13,5 \%$ & $14,2 \%$ & $0,7 \%$ \\
\hline
\end{tabular}

** significativo ao nivel de $1 \%$

Tabela 14. Evolução da Predisposição para cometer Fraude Académica (2011-2013) 
No caso da denúncia da fraude, os resultados sugerem que aumenta a predisposição dos alunos para denunciarem a invenção de dados e a obtenção de ajuda de um familiar. Em termos mais agregados, quando se compara o IPF e o IPD destes alunos entre 2011 e 2013, constata-se que ambos registaram evoluções estatisticamente significativas, tendo diminuído o IPF e aumentado o IPD. Ou seja, parece confirmar-se uma tendência para, ao longo do seu percurso académico, os alunos desenvolverem um critério mais rigoroso em relação à sua conduta académica e à dos outros. A Tabela 15 apresenta essa evidência.

\begin{tabular}{lccc}
\cline { 2 - 3 } & $\begin{array}{c}\mathrm{Em} \mathrm{2011} \\
(1-10)\end{array}$ & $\begin{array}{c}\mathrm{Em} \mathrm{2013} \\
(1-10)\end{array}$ & diferença \\
\hline Indicador de Predisposição para Fraude (IPF) & 3,71 & 3,49 & $-0,23^{* *}$ \\
Indicador da Predisposição para a Denúncia (IPD) & 0,81 & 1,04 & $0,22^{* *}$ \\
\hline
\end{tabular}

** significativo ao nivel de $1 \%$

Tabela 15. Evolução do IPF e do IPD (2011-2013)

Curiosamente, o IPD apresenta uma correlação positiva e significativa com o ISA ${ }^{35}$. Ou seja, quanto mais satisfeito o aluno está com o seu contexto académico, maior a sua predisposição para denunciar a fraude observada. Já o IPF não parece sofrer impacto significativo da satisfação do aluno. Embora esta amostra não permita a generalização da anterior, isto parece sugerir que a satisfação com o ambiente e o percurso académico favorece mais o rigor em relação aos outros do que em relação a si mesmo.

\section{Os Motivos da Fraude}

Quanto aos motivos da fraude, estes alunos tendem a valorizar significativamente mais aqueles que responsabilizam a instituição

35 Coeficiente de Correlação de Spearman 0,116 (significativo ao nível de 5\%). 
e os seus agentes. Na Tabela 16 é apresentada a evolução das opiniões sobre os motivos que poderão levar os alunos a cometerem fraude académica.

\begin{tabular}{|c|c|c|c|}
\hline & \\
\hline & $\begin{array}{l}\mathrm{Em} 2011 \\
(1-5)\end{array}$ & $\begin{array}{l}\mathrm{Em} 2013 \\
(1-5)\end{array}$ & diferença \\
\hline Assegurar o sucesso a uma disciplina à qual já se reprovou & 3,98 & 3,91 & $-0,07$ \\
\hline Carga de trabalho académico & 3,59 & 3,48 & $-0,11$ \\
\hline Hábito de uma conduta fraudulenta desde o ensino secundário & 3,58 & 3,64 & 0,06 \\
\hline Insegurança sobre a capacidade de alcançar o sucesso de outra forma & 3,45 & 3,36 & $-0,09$ \\
\hline Regularidade da prática fraudulenta entre colegas & 3,19 & 3,38 & $0,19 * *$ \\
\hline Modalidades de avaliação & 3,11 & 3,18 & 0,07 \\
\hline Passividade dos professores perante situações de fraude & 3,09 & 3,34 & $0,25^{* *}$ \\
\hline Pouca relevância prática atribuída aos conteúdos curriculares & 2,90 & 3,06 & $0,16^{*}$ \\
\hline $\begin{array}{l}\text { Perceção de que a pena, no caso de ser descoberta a fraude, é pouco } \\
\text { significativa }\end{array}$ & 2,89 & 3,14 & $0,25^{* *}$ \\
\hline Falta de conhecimento sobre qual deve ser a boa conduta académica & 2,73 & 2,62 & $-0,11$ \\
\hline Pressão competitiva entre os colegas & 2,65 & 2,72 & 0,07 \\
\hline Falta de debate sobre o assunto nas aulas com os professores & 2,64 & 2,55 & $-0,09$ \\
\hline Competência pedagógica insuficiente dos professores & 2,52 & 2,74 & $0,22 * *$ \\
\hline
\end{tabular}

Tabela 16. Evolução da Opinião sobre os Motivos da Fraude Académica (2011-2013)

Estes alunos, dois anos depois, parecem valorizar mais como motivos para cometer fraude, aqueles que a permitem que seja praticada do que aqueles que despertam o desejo de praticá-la. Ou seja, trata-se da valorização de motivadores extrínsecos, facilitadores da ação desejada, e não motivadores intrínsecos, determinantes desse desejo. Identifica-se como motivos mais relevantes do que no passado a passividade e incompetência dos professores, o desinteresse de conteúdos lecionados ou a insuficiência das penas ou da vigilância que não evita a prática regular de fraude. À medida que acumulam experiência académica, os alunos parecem tender a responsabilizar mais a instituição e os seus agentes pela facilitação da fraude. 


\section{Os Inibidores da Fraude}

Quanto aos inibidores da fraude, aumentou a importância atribuída por estes alunos aos meios dissuasores de vigilância e controlo para um combate mais eficaz à prática transgressora. Por outro lado, parece menos relevante o efeito da formação preventiva dos alunos. Na Tabela 17 apresentam-se as importâncias atribuídas por estes alunos a cada um dos inibidores de fraude em 2011 e 2013.

\begin{tabular}{|c|c|c|c|}
\hline & $\begin{array}{c}\operatorname{Em~} 2011 \\
(1-5)\end{array}$ & 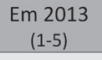 & diferença \\
\hline Agravamento das penas para conduta académica fraudulenta & 3,90 & 3,83 & $-1,07$ \\
\hline Impedir telemóveis ligados na sala onde se realizam exames & 3,60 & 3,56 & $-0,49$ \\
\hline $\begin{array}{l}\text { Utilização de mecanismos de vigilância e de deteção eletrónica de } \\
\text { fraude }\end{array}$ & 3,40 & 3,60 & $3,06^{* *}$ \\
\hline Existência de uma relação de proximidade entre professores e alunos & 3,28 & 3,39 & 1,58 \\
\hline $\begin{array}{l}\text { Garantia de anonimato na denúncia de comportamentos fraudulentos } \\
\text { dos colegas }\end{array}$ & 3,28 & 3,40 & 1,20 \\
\hline $\begin{array}{l}\text { Envolvimento dos estudantes na divulgação de boas práticas } \\
\text { académicas }\end{array}$ & 3,25 & 3,02 & $-3,39 * *$ \\
\hline Frequência de programas de apoio psicopedagógico & 3,21 & 3,13 & $-1,20$ \\
\hline $\begin{array}{l}\text { Frequência de programas de desenvolvimento de competências } \\
\text { académicas }\end{array}$ & 3,17 & 3,15 & $-0,30$ \\
\hline $\begin{array}{l}\text { Entrega de uma declaração de autoria/originalidade dos trabalhos } \\
\text { apresentados para avaliação }\end{array}$ & 3,06 & 2,94 & $-1,56$ \\
\hline Divulgação de um Código de Conduta da escola & 2,97 & 2,78 & $-2,61^{* *}$ \\
\hline $\begin{array}{l}\text { Sessões de esclarecimento promovidas pela escola sobre a boa } \\
\text { conduta académica }\end{array}$ & 2,67 & 2,67 & 0,00 \\
\hline Existência de provas orais obrigatórias & 2,66 & 2,75 & 1,74 \\
\hline Frequência de disciplinas sobre Ética & 2,63 & 2,47 & $-2,25^{*}$ \\
\hline $\begin{array}{l}\text { Divulgação no ambiente escolar do nome dos alunos que praticaram } \\
\text { fraudes }\end{array}$ & 2,53 & 2,78 & $3,32 * *$ \\
\hline
\end{tabular}

* significativo ao nivel de $5 \%$

** significativo ao nível de $1 \%$

Tabela 17. Evolução da Opinião sobre os Inibidores da Fraude Académica (2011-2013)

Segundo os dados, aumentam significativamente de importância, como potenciais inibidores da fraude, a utilização de mecanismos de vigilância e de deteção eletrónica de fraude e a divulgação no ambiente escolar do nome dos alunos que praticaram fraudes. Por 
outro lado, são desvalorizados o envolvimento dos estudantes na divulgação de boas práticas académicas, a divulgação de um Código de Conduta da escola e a frequência de disciplinas sobre Ética. Estes resultados parecem traduzir uma atitude mais pragmática por parte dos alunos, descrentes numa regeneração moral através da educação e mais confiantes no efeito dissuasor da ameaça da exposição pública e da vigilância ativa. 


\title{
C A P ÍT U L O I I I
}

\section{A TOLERÂNCIA DOS PROFESSORES}

\author{
À FRAUDE ACADÉMICA
}

COMETIDA POR ALUNOS EM PORTUGAL

\subsection{O estudo dos professores em Portugal}

\subsubsection{Objetivos do estudo}

Os estudos sobre a fraude académica cometida por alunos no ensino superior incidem habitualmente sobre a análise das perceções, opiniões e práticas dos alunos. No entanto, o fenómeno da fraude é multidimensional, envolvendo sempre pelo menos o aluno que a comete e o docente que a ignora ou a deteta. Visando provocar uma distorção favorável ao aluno na justiça da avaliação do seu desempenho, a eficácia da fraude por ele cometida dependerá do comportamento do docente que o avalia. Por isso, para compreender as suas diversas dimensões, é relevante conhecer também o pensamento e a atitude dos docentes em relação à prática fraudulenta dos alunos.

Com o objetivo de enriquecer o entendimento da fraude académica cometida por alunos do ensino superior em Portugal, foi realizado, simultaneamente com o estudo sobre a atitude dos alunos, um estudo sobre a atitude dos docentes. Em concreto, a finalidade deste estudo é conhecer qual a perceção dos docentes sobre a frequência das práticas de fraude, a gravidade que lhes atribuem, os 
seus motivos e os seus inibidores. Complementarmente, buscou-se também conhecer qual a reação dos docentes perante o aluno que comete fraude, quais os fatores que poderão inibi-los de denunciar a fraude observada e qual o rigor que têm na prevenção, deteção e vigilância do comportamento dos alunos.

\subsubsection{Seleção da amostra de professores}

O estudo sobre os docentes em Portugal foi alargado ao universo de docentes do ensino superior público e privado, sem distinguir áreas científicas ou instituições de ensino. O objetivo foi obter o maior número possível de respostas, sem preocupação com a representatividade da amostra final, mas também sem restringi-la à rede de contactos dos autores do estudo.

\subsubsection{O método de recolha de dados}

O contacto com os docentes e a solicitação para participarem no estudo foi realizado por $e$-mail, tendo sido utilizada uma base de dados tão ampla quanto possível com o contacto eletrónico dos docentes ativos no ensino superior em Portugal. Para o efeito, foi efetuada uma recolha de endereços de $e$-mail de docentes do ensino superior a partir das páginas das instituições de ensino superior na Internet. A recolha permitiu reunir 10.359 endereços de e-mail válidos, constituindo cerca de $35 \%$ do total de docentes do ensino superior à data, para os quais foi enviado convite de participação no inquérito. Para recolher as suas respostas, foi disponibilizada online uma versão similar do questionário que foi aplicado presencialmente aos alunos. A recolha de dados foi efetuada durante o segundo semestre do ano letivo 2011/2012, tendo ocorrido mais precisamente entre o dia 19/01/2012 e o dia 03/08/2012. 


\subsubsection{O Questionário}

Tal como o questionário dos alunos, este também incluía essencialmente perguntas de resposta fechada e era constituído por 3 partes, com a seguinte estrutura ${ }^{36}$ :

- PARTE I: continha 12 questões e destinava-se genericamente a recolher dados demográficos do docente, exceto a questão I.11 (na qual se pretendia saber se o docente sabia e conhecia o regulamento disciplinar da sua instituição) e a questão I.12 (na qual se pretendia conhecer qual a perceção geral do docente em relação à frequência da prática de fraude entre os alunos).

- PARTE II: apresentava exatamente os mesmos 9 cenários (oito situações e uma delas desdobrada em duas) apresentados aos alunos, envolvendo personagens fictícias em práticas de possível fraude académica, sendo solicitada a sua opinião sobre a gravidade de cada prática.

- PARTE III: continha 8 questões de escolha múltipla, coincidindo 4 com aquelas apresentadas aos alunos para avaliar a sua opinião sobre a aceitabilidade da fraude académica, a frequência de algumas práticas, os fatores que a motivam e os fatores que a poderão inibir; as restantes 4 questões eram específicas para os docentes, questionando-os sobre como reagem perante a fraude observada, o que os poderá inibir de denunciá-la, qual o rigor da sua prática de vigilância e prevenção da fraude e qual o seu grau de satisfação profissional.

Um dos objetivos deste questionário é permitir comparar as perceções e opiniões dos alunos com as perceções e opiniões dos docentes, o que explica a utilização dos mesmos cenários e o ques-

36 O ANEXO 2 "Questionário aos Professores" apresenta o questionário completo, tal como foi aplicado neste estudo. 
tionamento sobre as mesmas práticas, motivos e inibidores. Embora não exista uma comparação direta entre alunos e docentes que interajam entre si, a análise comparada das amostras de alunos e de docentes permite vislumbrar como, em termos agregados, estes dois grupos se relacionam com a fraude académica.

\subsubsection{Descrição da amostra final}

Após validação dos questionários recebidos, a amostra final fixou-se em 2.727 docentes do ensino superior em Portugal, representando uma taxa de resposta de $26,3 \%$ em relação ao total de docentes contactados. Todos os docentes incluídos na amostra têm nacionalidade portuguesa e 48,7\% são mulheres. Quanto ao grau académico, 61,8\% possuem doutoramento.

A quase totalidade dos docentes da amostra leciona no setor público (93,7\%), sendo que apenas 6,3\% leciona no setor privado. Também 54,8\% são docentes na Universidade (destes, 92,7\% no setor público e 7,3\% no setor privado) e 45,2\% são docentes no Politécnico (destes, $94,9 \%$ no setor público e 5,1\% no setor privado). Há portanto uma prevalência de docentes do ensino público universitário na amostra final, consistente com a presença maioritária deste setor no espectro do ensino superior em Portugal.

O questionário incluía também, além de perguntas relacionadas com a fraude académica e com a satisfação profissional dos docentes, questões destinadas a avaliar o seu grau de conhecimento sobre os mecanismos institucionais de prevenção e resposta a situações de fraude na instituição onde lecionam. Curiosamente, 30,7\% respondeu não saber se a sua instituição tem código de boas práticas ou regulamento disciplinar, o que revela um certo distanciamento da classe docente em relação a estes meios de resposta formal. Além disso, dos $37,1 \%$ que dizem que existe código de boas práticas ou regulamento disciplinar, 13\% ainda não leu. Estes resultados mostram que uma 
parte significativa dos docentes valoriza pouco os dispositivos formais de resposta a situações de fraude potencial ou concretizada entre os alunos. O desinteresse dos docentes em relação a estes dispositivos institucionais de regulação da conduta académica constitui um sério obstáculo ao combate à fraude cometida pelos alunos e representa um sinal preocupante de distanciamento em relação ao governo das instituições ou de desconfiança em relação à eficácia dos seus regulamentos.

\subsection{A satisfação académica dos professores}

O comprometimento dos docentes com a prevenção, vigilância, deteção e resposta perante situações de fraude cometidas por alunos é essencial para o bom sucesso de qualquer política institucional de combate à fraude no ensino superior. O grau desse compromisso pode estar associado ao grau de satisfação com a circunstância académica e profissional, determinando a maior ou menor disponibilidade de cada docente para combater ativamente ou negligenciar passivamente a fraude cometida pelos alunos. Por isso, apesar de todas as perguntas realizadas aos docentes estarem relacionadas com a sua perceção sobre aspetos da fraude académica, a última pergunta do questionário pretendia avaliar o seu grau de satisfação, numa escala entre 1 e 10, em relação a três dimensões: i) com a sua função de professor no ensino superior; ii) com a instituição onde leciona; iii) e com a política da sua instituição em relação à fraude académica.

Os resultados mostram que os docentes estão razoavelmente satisfeitos com a sua função e com a instituição onde lecionam, embora menos satisfeitos com a política daquela em relação à fraude. A Tabela 18 apresenta os três níveis de satisfação e um nível geral correspondente à média dos anteriores ${ }^{37}$.

37 A análise dos dados sugere que os três indicadores de satisfação podem ser combinados num único indicador, dado que todos estão fortemente correlacionados 


\section{Satisfação Académica dos Professores}

(1-10)

\begin{tabular}{lc}
\hline Satisfação com a sua função de professor no ensino superior & 7,93 \\
\hline Satisfação com a instituição onde leciona & 7,34 \\
\hline Satisfação com a política da sua instituição em relação à fraude académica & 5,74 \\
\hline Indicador de Satisfação Académica (ISA) & 7 \\
\hline
\end{tabular}

Tabela 18. Satisfação Académica dos Professores

Como se constata, o nível agregado de satisfação dos docentes, representado pelo Indicador de Satisfação Académica (ISA) é de 7, numa escala entre 1 e 10. Embora a análise dos dados sugira a utilização de um único indicador, é interessante verificar que existe uma clara diminuição do nível de satisfação quando considerada a política institucional de combate à fraude, sugerindo uma crítica subjacente à eficácia ou ao modelo de resposta institucional perante situações de fraude académica.

Quando cruzado o ISA com as características demográficas dos docentes, constata-se que ele é maior nos docentes do setor privado (ISA 7,63) do que do setor público (ISA 6,96) ${ }^{38}$, nos docentes do ensino politécnico (ISA 7,10) do que do ensino universitário (ISA 6,92) 39 , nos docentes que reconhecem existir regulamento disciplinar na sua instituição (ISA 7,57) do que naqueles que afirmam não existir (ISA 6,50$)^{40}$, nos docentes que consideram existir menos fraude na

entre si, que a Análise Fatorial Exploratória sugere um único fator (KMO, 0.622, sig. 0.000 , eigenvalue superior a 1 , com variância explicada de $69,11 \%$ ) e que o alfa de Cronbach é 0,757 .

\footnotetext{
38 t-Student 4,847 (p-value 0,000)

39 t-Student 2,500 ( $p$-value 0,012 )

40 t-Student 13,519 (p-value 0,000)
} 
sua instituição ${ }^{41}$, nos docentes mais $\operatorname{novos}^{42}$ e nos docentes com menos experiência académica 43 .

Segundo os resultados, aparentemente os docentes do ensino politécnico estão significativamente mais satisfeitos do que os docentes do ensino universitário com a sua circunstância académica. Esta diferença reflete uma porventura maior capacidade de resposta do subsistema de ensino superior politécnico às expectativas e ambições dos docentes que o integram. É também interessante constatar que a satisfação está associada ao conhecimento dos docentes sobre a existência de mecanismos de regulação da conduta académica dos alunos, podendo esta relação entre satisfação e reconhecimento dos dispositivos institucionais ser reciprocamente alimentada. Por fim, verifica-se uma tendência para a redução dos níveis de satisfação académica dos docentes à medida que envelhecem e que acumulam experiência no ensino superior, o que, não sendo desejável, é comum na generalidade das atividades profissionais devido à acomodação das rotinas, ao desinvestimento na relação pedagógica ou ao abrandamento de novos desafios.

Quando comparados os resultados sobre cada uma das dimensões de satisfação, confirma-se a existência de uma diferença consistente entre docentes dos vários subsistemas de ensino. A Tabela 19 apresenta esses resultados.

41 Teste $\mathrm{F} 101,977$, p-value 0,000 (aumentando a satisfação à medida que diminui a regularidade com que percecionam a fraude no seu contexto: Coeficiente de Correlação de Spearman -0,319 (significativo ao nível de 1\%))

42 Coeficiente de Correlação de Spearman 0,049 (significativo ao nível de 1\%).

43 Coeficiente de Correlação de Spearman 0,128 (significativo ao nivel de 1\%). 


\begin{tabular}{|c|c|c|c|c|}
\hline & \multicolumn{4}{|c|}{ Subsistema de Ensino Superior } \\
\hline & Universitário & Politécnico & Público & Privado \\
\hline & N 1459 & N 1198 & N 2487 & N 169 \\
\hline \multirow[t]{2}{*}{$\begin{array}{l}\text { Satisfação com a sua função de professor no } \\
\text { ensino superior }\end{array}$} & 7,90 & 7,96 & 7,92 & 8,06 \\
\hline & N 1455 & N 1191 & N 2475 & N 170 \\
\hline \multirow[t]{2}{*}{ Satisfação coma instituição onde leciona } & 7,28 & 7,39 & 7,31 & 7,66 \\
\hline & N 1443 & N 1184 & N 2457 & N 169 \\
\hline $\begin{array}{l}\text { Satisfação com a política da sua instituição em } \\
\text { relação à fraude académica }\end{array}$ & 5,60 & 5,91 & 5,64 & 7,14 \\
\hline
\end{tabular}

Tabela 19. Satisfação Académica dos Docentes (por subsistema de ensino)

Por um lado, confirma-se que os níveis de satisfação são em geral maiores nos docentes do ensino politécnico do que nos docentes do ensino universitário, com uma diferença mais significativa no caso da satisfação com a política institucional de combate à fraude académica. Talvez a dimensão das instituições, tendencialmente menores no ensino politécnico, favoreça um combate mais eficaz à fraude, quer por via da agilidade administrativa na gestão de procedimentos, quer por via da proximidade da relação entre docentes e alunos. Por outro lado, os docentes do ensino privado apresentam níveis significativamente maiores de satisfação do que os docentes do ensino público, no entanto, o número baixo de docentes do ensino privado que responderam ao questionário não permite generalizar com segurança esta tendência. Em todo o caso, os resultados confirmam um grau considerável de satisfação com a carreira e com a instituição, sendo transversal um olhar mais crítico dos docentes relativamente às respostas institucionais perante o fenómeno da fraude académica. 


\subsection{A sensibilidade dos professores à fraude dos alunos}

No questionário respondido pelos docentes foram apresentados os mesmos nove cenários simulados de fraude académica cometida por alunos que também constavam do questionário respondido pelos alunos. Aos docentes, tal como aos alunos, foi solicitado que indicassem, para cada uma das 13 práticas de fraude ( 7 de apropriação, 4 de facilitação e 2 de simulação) incluídas nos cenários, o grau de gravidade que lhe atribuíam, numa escala que varia entre 1 e 10 . A gravidade atribuída por cada docente às práticas de fraude é um indicador da sua sensibilidade perante a fraude, na medida em que reflete a ressonância moral que estas têm no seu sistema de crenças, através da quantificação da importância da fraude enquanto modo de conduta indesejável e prejudicial ao propósito do processo educacional e à justiça do processo avaliativo. Assim, a sensibilidade dos docentes à fraude cometida pelos alunos é medida pelo grau de gravidade que aqueles lhe atribuem, sendo tanto mais sensíveis quanto maior for a gravidade percecionada.

Segundo os docentes, as fraudes mais graves são comprar trabalho a colega (média de 9,74), plágio autorizado do trabalho de um colega (média de 9,31) e inventar dados num trabalho escrito (média de 9,25). Parece existir uma valorização maior, por parte dos docentes, das fraudes cometidas em trabalhos do que cometidas em exame escrito. A Tabela 20 apresenta as gravidades médias atribuídas pelos docentes a cada uma das práticas de fraude ${ }^{44}$.

${ }^{44}$ Um irreversível acidente informático impossibilitou a análise das respostas sobre a gravidade da fraude obtenção de ajuda de um familiar, pelo que se analisarão apenas as restantes 12 práticas de fraude. 


\begin{tabular}{|llc|} 
& & Gravidade da prática \\
& & $(1-10)$ \\
\hline 1 & Comprar trabalho a colega & $\mathbf{9 , 7 4}$ \\
\hline 2 & Plágio autorizado do trabalho de um colega & $\mathbf{9 , 3 1}$ \\
\hline 3 & Inventar dados num trabalho escrito & $\mathbf{9 , 2 5}$ \\
\hline 4 & Vender aos colegas trabalhos realizados por si próprio & $\mathbf{9 , 0 8}$ \\
\hline 5 & Copiar trabalho da Internet & $\mathbf{8 , 7 1}$ \\
\hline 6 & Copiar respostas de um colega numa prova escrita & $\mathbf{8 , 6 2}$ \\
\hline 7 & Consultar materiais não autorizados numa prova escrita & $\mathbf{8 , 4 2}$ \\
\hline 12 & $\begin{array}{l}\text { Emprestar a colegas trabalho realizado por si próprio para que estes } \\
\text { apresentem como seu }\end{array}$ & $\mathbf{8 , 2 7}$ \\
\hline 9 & Fornecer respostas a um colega num exame & $\mathbf{8 , 0 4}$ \\
\hline 10 & Não participar em trabalho de grupo, beneficiando da nota coletiva & $\mathbf{7 , 7 3}$ \\
\hline 11 & Apresentar o mesmo trabalho em diferentes disciplinas & $\mathbf{6 , 8 9}$ \\
\hline
\end{tabular}

Tabela 20. Gravidade da Fraude Académica (opinião dos docentes)

As respostas dos docentes sugerem que há uma condenação maior das práticas ativas do que das práticas passivas, exceto no caso da venda de trabalhos que é considerada a mais grave das práticas passivas. Curiosamente, no âmbito das práticas ativas de fraude, a elevada gravidade atribuída ao plágio autorizado de um trabalho parece contrastar com a menor gravidade atribuída ao benefício de uma nota coletiva sem ter participado no trabalho de grupo. Embora sejam práticas com características idênticas, talvez os docentes tendam a reconhecer que, no âmbito da sua liberdade de decisão sobre como repartir internamente as tarefas, o grupo de trabalho assume solidariamente as consequências da injustiça provocada por uma nota coletiva. Ou, por outro lado, poderão os docentes acreditar 
que nestes casos talvez exista sempre um processo de aprendizagem marginal, favorecido por cumplicidades recíprocas, que não é inteiramente desperdiçado num trabalho de grupo e que, por essa via, diminui o efeito nocivo da fraude.

Os resultados confirmam também a suspeita de que os docentes atribuem mais gravidade a todas as fraudes do que os alunos. Quando comparadas as opiniões de ambos os grupos, verifica-se que elas distanciam-se mais, entre as práticas menos graves, no caso da apresentação do mesmo trabalho em diferentes disciplinas e, entre as práticas mais graves, no caso da invenção de dados num trabalho escrito. No Gráfico 11 são apresentadas as gravidades atribuídas pelos docentes pelos alunos a cada uma das práticas analisadas.

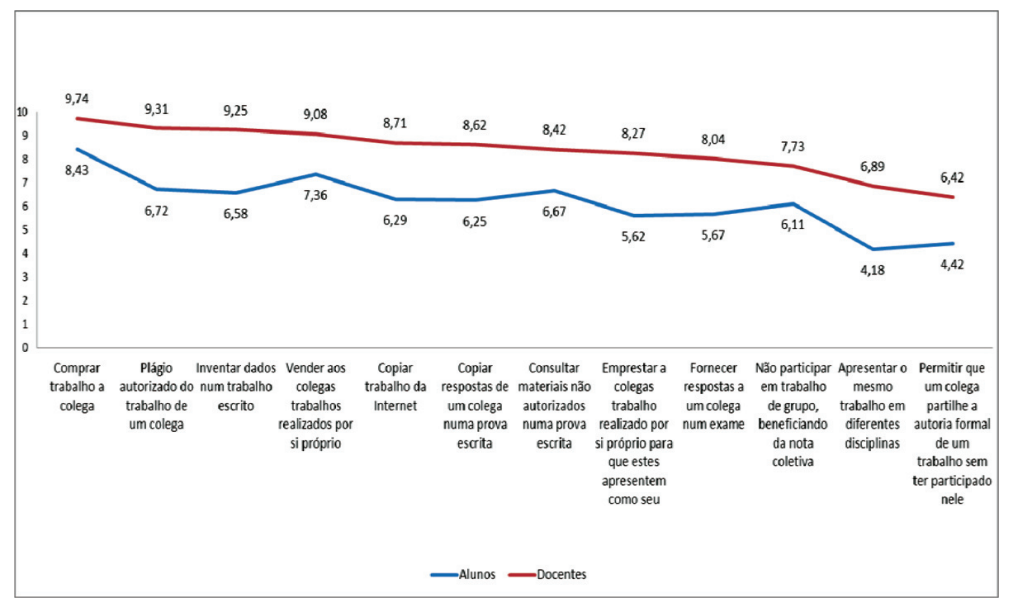

Gráfico 11. Perceção sobre Gravidade da Fraude Académica (alunos e docentes)

Com base nestas perceções dos docentes, é possível calcular o ISF (Indicador de Sensibilidade à Fraude) de cada docente a partir da média das gravidades que ele atribui às práticas fraudulentas. Assim, o ISF constitui-se como um indicador quantitativo do grau médio de 
gravidade que cada docente atribui à fraude académica, variando numa escala entre 1 e 10. Para a amostra inquirida de docentes do ensino superior em Portugal, o ISF é de 8,37. Quando analisado à luz das características demográficas e outras perceções dos docentes, constata-se que o ISF é significativamente maior $\mathrm{em}^{45}$ :

. docentes mulheres (ISF 8,55) do que em docentes homens (ISF 8,21)

. docentes que sabem se existe ou não existe código de boas práticas na sua instituição do que naqueles que desconhecem se existe

. docentes que, reconhecendo existir regulamento disciplinar, já o leram (ISF 8,49) do que naqueles que não o leram (ISF 8,12)

. docentes com mestrado ou doutoramento do que naqueles apenas com licenciatura

. docentes mais velhos e com mais anos de experiência académica

. docentes que consideram a fraude inaceitável em qualquer circunstância (ISF 8,41) do que entre aqueles que a consideram aceitável em determinadas circunstâncias (ISF 6,76)

Estes resultados sugerem que as mulheres tendem a atribuir maior gravidade à fraude do que os homens, o que se explica pela desigual distribuição de poder numa sociedade tradicionalmente dominada por homens. Ou seja, as classes mais poderosas tendem a conviver melhor com a transgressão, dada a posição dominante que em geral as preserva do abuso, lhes confere um sentido de impunidade e protege contra a denúncia. Talvez os docentes homens tenham inconscientemente esse sentimento de impunidade desculpabiliza-

45 Os resultados dos testes estatísticos estão incluídos no ANEXO 4.8. 
dora que transferem para a avaliação moral da gravidade da fraude cometida pelos alunos. Por outro lado, também os docentes mais velhos e com mais experiência académica tendem a revelar-se mais sensíveis à gravidade da fraude, o que pode significar que à medida que se conhece melhor o contexto de ensino, aumenta a consciência dos malefícios coletivos que a fraude académica pode gerar. Esta sensibilidade que se desenvolve com a experiência, sendo fruto da maturidade, é um sinal evidente do combate preventivo que deve ser travado contra este tipo de transgressão, capaz de corroer os alicerces da confiança recíproca em que se baseiam as sociedades mais justas.

\subsection{A intolerância dos professores à fraude dos alunos}

No questionário dos docentes, foi incluída uma pergunta que visava avaliar o seu grau de intolerância à fraude. Se a sensibilidade se refere à gravidade que se atribui à fraude (sendo portanto uma disposição moral, ligada ao pensamento), a intolerância refere-se ao rigor com que ela é combatida (sendo portanto uma disposição comportamental, ligada à ação concreta $)^{46}$. Nestes termos, foi solici-

46 Uma breve clarificação filosófica sobre a diferença entre os conceitos de Sensibilidade e Intolerância, tal como adotados neste estudo: sensibilidade refere-se à permeabilidade dos sentidos às impressões exteriores e portanto, neste caso, refere-se ao quão grave se considera a fraude, refletindo a importância atribuída ao seu significado moral. Tolerar significa suportar a dor (física ou psicológica), ou seja, não reagir perante um "mal". No campo moral, tolerar significa permitir e portanto a intolerância implica sempre ação. Por exemplo, se eu sou intolerante ao racismo, não fico calado se alguém fizer um comentário racista. Se eu ficar calado e nada disser ou fizer, fui tolerante, apesar de achar grave (ou seja, apesar de ser sensível). Em ética, não tolerar implica necessariamente agir, porque o seu contrário é tolerar. Assim, neste estudo a Sensibilidade mede a opinião e a Intolerância mede a ação. Por exemplo, eu posso achar que é um risco elevado investir em ouro (sensibilidade elevada) e mesmo assim investir (tolerante a esse risco percecionado). Ou posso achar que é muito grave trair (sensibilidade elevada) e abandonar quem me traiu (intolerante à traição). 
tado aos docentes que autoavaliassem o grau de rigor, numa escala entre 1 e 10, que consideravam ter em três práticas concretas da sua atividade docente: prevenção da fraude (cautelas que toma para evitar a fraude de alunos); verificação e controlo da fraude (procedimentos que adota para verificar se há fraude); e vigilância de exames (verificação da fraude em exames escritos).

O grau de intolerância de cada docente perante a fraude cometida pelos alunos foi então materializado no indicador IIF (Indicador de Intolerância à Fraude), calculado com base na média dos graus de rigor atribuídos pelos docentes às três práticas autoavaliadas ${ }^{47}$. Em Portugal, para o conjunto de docentes inquiridos, o IIF é de $\mathbf{8 , 1 8}$, refletindo um empenho significativo que os docentes reconhecem ter no combate à fraude académica. Na Tabela 21 são apresentadas médias das respostas dos docentes.

\begin{tabular}{lc}
$\begin{array}{l}\text { Na sua prática docente, como considera ser a sua atitude nas seguintes } \\
\text { circunstâncias? }\end{array}$ & $\begin{array}{c}\text { Grau de Rigor } \\
(1-10)\end{array}$ \\
\hline Prevenção da fraude (cautelas que toma para evitar a fraude de alunos) & 8,17 \\
\hline Verificação e controlo da fraude (procedimentos que adota para verificar se há fraude) & 8 \\
\hline Vigilância de exames (verificação da fraude em exames escritos) & 8,36 \\
\hline Indicador de Intolerância à Fraude (IIF) & $\mathbf{8 , 1 8}$ \\
\hline
\end{tabular}

Tabela 21. Intolerância dos Professores à Fraude

Com elevado grau de intolerância, os docentes parecem significativamente empenhados na prevenção, controlo e vigilância da fraude académica cometida pelos alunos. Este resultado é consistente com

${ }^{47}$ A análise dos dados sugere que as três práticas autoavaliadas possam de facto ser conjugadas num único indicador agregado, uma vez que todos estão fortemente correlacionados entre si, que a Análise Fatorial Exploratória sugere um único fator (KMO, 0,730, sig. 0,000, eigenvalue superior a 1, com variância explicada de 77,4\%) e que o alfa de Cronbach é 0,854 . 
o elevado nível de sensibilidade revelado pelos docentes em relação à fraude, sugerindo que se dispõem a agir em conformidade com a gravidade que atribuem ao fenómeno. Quando analisado o perfil dos docentes em função do seu IIF, verifica-se que a intolerância à fraude é significativamente maior $\mathrm{em}^{48}$ :

. docentes mulheres (IIF 8,34) do que em docentes homens (IIF 8,03)

. docentes do setor privado (IIF 8,45) do que do setor público (IIF 8,16)

. docentes do ensino politécnico (IIF 8,27) do que do ensino universitário (IIF 8,10)

. docentes que reconhecem existir regulamento disciplinar na sua instituição (IIF 8,43) do que naqueles que afirmam não existir (IIF 8,11)

. docentes que, reconhecendo existir regulamento disciplinar, já o leram (IIF 8,48) do que naqueles que não o leram (IIF 8,04)

É interessante constatar que, em termos de sensibilidade dos docentes à fraude, não se distinguem significativamente os subsistemas de ensino público e politécnico, sendo homogénea a forma como os docentes avaliam a gravidade das práticas fraudulentas. No entanto, quando se analisa a intolerância dos docentes, o ensino politécnico parece sobressair como um contexto onde os docentes autodeclaram-se mais rigorosos no combate à fraude. Talvez também por isso o seu grau de satisfação com a política institucional de combate à fraude seja significativamente maior do que aquele revelado pelos docentes do ensino universitário. O envolvimento dos docentes neste combate é condição essencial para o seu êxito.

48 Os resultados dos testes estatísticos estão incluídos no ANEXO 4.9. 
Pode ser que no ensino politécnico, pela sua dimensão e modelos de gestão, os docentes sintam mais amparo e incentivo institucional a desenvolverem uma atitude preventiva e fiscalizadora da fraude. Em todo o caso, os níveis gerais de empenho são elevados em ambos os subsistemas de ensino, revelando uma disponibilidade elevada para combater um "mal" que é amplamente reconhecido como grave entre a classe docente em Portugal.

Por fim, quando comparados o IIF, o ISF e o ISA entre si, verifica-se que todos estão significativamente relacionados entre si. Ou seja, por um lado, à medida que aumenta a sensibilidade à fraude (ISF), também aumenta a intolerância à fraude (IIF) ${ }^{49}$, ou seja, os docentes revelam-se dispostos a tolerar menos a fraude à medida que a consideram mais grave, agindo em função de uma disposição moral. Por outro lado, à medida que aumenta a satisfação académica (ISA), também aumenta a sensibilidade à fraude (ISF) e a intolerância à fraude (IIF) ${ }^{50}$, o que significa que a satisfação com as circunstância académicas está associada a uma atitude docente mais atenta e exigente em relação ao contexto, dispondo-se a agir sobre ele em conformidade com essa sensibilidade. Embora seja um resultado previsível, é interessante confirmar que o combate ativo à fraude pelos docentes, tratando-se de uma peça fundamental de qualquer política que vise minimizar essas práticas, depende da sua satisfação e realização académicas. A atitude interventiva dos docentes neste combate resulta portanto do seu comprometimento emocional com a instituição, sendo insuficiente qualquer medida que não tenha em conta esta dimensão crítica relacionada com a motivação do corpo docente e com a sua interpretação das condições institucionais e académicas em que desenvolve a sua carreira.

49 Coeficiente de Correlação de Spearman 0,366 (significativo ao nível de 1\%)

50 ISA e ISF: Coeficiente de Correlação de Spearman 0,089 (significativo ao nível de 1\%); ISA e IIF: Coeficiente de Correlação de Spearman 0,229 (significativo ao nível de 1\%) 


\subsection{A perceção dos professores sobre as práticas de fraude dos alunos}

\subsubsection{A frequência da fraude}

Tal como no caso dos alunos, também no caso dos docentes buscou-se conhecer a sua perceção sobre a frequência com que os alunos da sua instituição cometem fraude académica. Segundo os resultados, $66 \%$ dos docentes consideram que os alunos cometem fraude com alguma frequência ou regularmente. No Gráfico 12 são apresentados os resultados das respostas dos docentes e comparados com as respostas dos alunos.

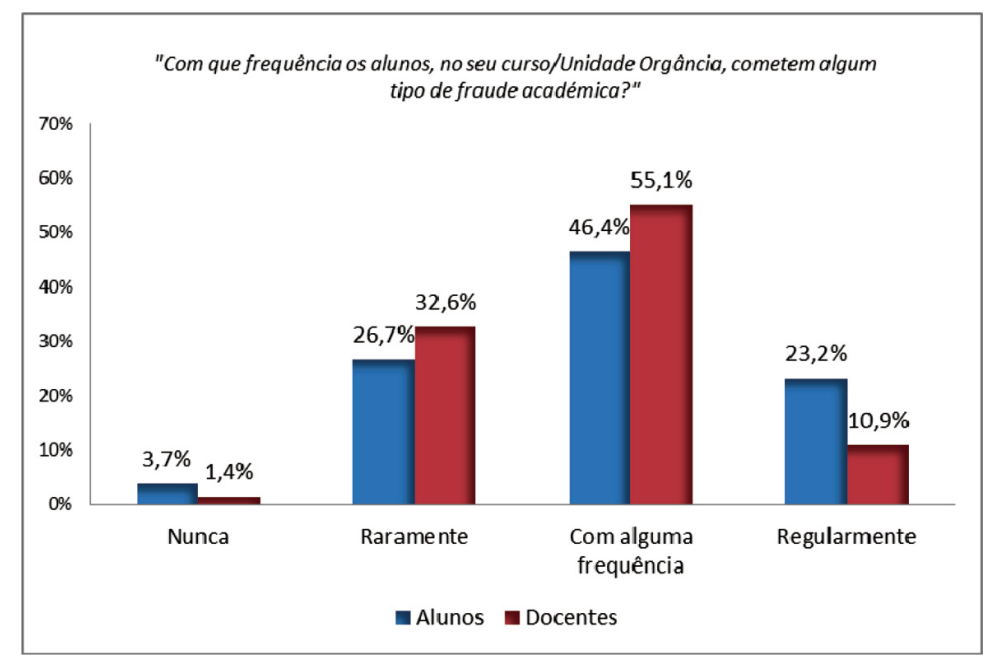

Gráfico 12. Perceção sobre Frequência da Fraude Académica (alunos e docentes)

É curioso verificar que a percentagem de alunos a considerar que "nunca" se comete fraude académica no seu contexto escolar é maior do que a percentagem de docentes com a mesma opinião, ao mesmo tempo que, tal como seria previsível, também é significativamente 
maior a percentagem de alunos que consideraram que se comete fraude "regularmente". Proporcionalmente, há mais docentes do que alunos a manifestar a opinião de que a fraude ocorre "raramente" ou " com alguma frequência". Estes resultados comparados sugerem duas observações: primeiro, confirma-se que tanto a maioria dos alunos como a maioria dos docentes considera que os alunos cometem fraude com intensidade assinalável; segundo, os docentes parecem não percecionar que a fraude seja cometida com tanta regularidade como aquela relatada pelos alunos. Esta diferença de perceções sugere que talvez seja significativa a frequência com que os alunos cometem fraude que não é detetada.

Quanto aos docentes, a sua perceção também varia consoante algumas características demográficas específicas. A perceção sobre a frequência de práticas fraudulentas dos alunos é maior em docentes:

. mulheres

. do setor público

. do ensino universitário

. com mais anos de experiência como docente

. com maior qualificação (mestrado e doutoramento)

. que dizem não existir código de boas práticas na sua instituição

Os docentes foram igualmente questionados sobre a frequência com que consideravam serem cometidas 11 práticas de fraude concretas e a frequência com que os alunos as denunciam. Segundo os resultados, as práticas mais frequentes, na opinião dos docentes, são Copiar partes de trabalhos de outros autores sem os citar, Copiar trabalhos da Internet e Assinar um trabalho de grupo sem ter colaborado na realização do mesmo. Só em quinto lugar surge a prática que, na perspetiva dos alunos, é mais frequente: Utilizar materiais não 
autorizados na realização de provas escritas. A Tabela 22 apresenta as práticas de fraude, ordenadas segundo a perceção dos docentes quanto à sua frequência.

\section{Perceção sobre Frequência das Práticas de Fraude}

(por ordem de ocorrência)

\begin{tabular}{ll}
\hline 1 & Copiar partes de trabalhos de outros autores sem os citar \\
2 & Copiar trabalhos da Internet \\
3 & Assinar um trabalho de grupo sem ter colaborado na realização do \\
4 & Copiar trabalhos de outros colegas \\
5 & Utilizar materiais não autorizados na realização de provas escritas \\
6 & Copiar numa prova escrita pelas respostas de um colega \\
7 & Deixar um colega copiar as suas respostas num exame \\
\hline 8 & Apresentar o mesmo trabalho em várias disciplinas \\
9 & Apresentar trabalhos práticos com dados inventados \\
\hline 10 & Comprar trabalhos académicos fora da escola \\
11 & Comprar trabalhos a outros colegas \\
\hline
\end{tabular}

Tabela 22. Frequência das Práticas de Fraude Académica (perceção dos docentes)

De facto, quando comparadas as perceções dos docentes com as perceções dos alunos (ver Tabela 5), constata-se que os alunos tendem a reconhecer como mais frequentes as fraudes relacionadas com as provas escritas, enquanto os docentes claramente destacam as fraudes cometidas em trabalhos. ${ }^{51}$ Apesar desta dissonância de

51 Será importante notar que muitos professores inquiridos desenvolvem experiências de docência ao nível dos segundo e terceiro ciclos, onde as provas escritas são menos frequentes e a realização de trabalhos escritos mais recorrente. Ao passo que o questionário aplicado aos alunos não abrange alunos do segundo e terceiro ciclo. 
perceções, ambos os grupos de alunos e de docentes concordam que as fraudes menos frequentes estão relacionadas com a compra de trabalhos, dentro ou fora da instituição, ou seja, aparentemente a apropriação é feita sem que isso implique transação económica, apenas baseada em sistemas de cumplicidade ativa ou passiva.

Eis a síntese dos principais resultados sobre a frequência das práticas de fraude académica, segundo a perceção dos docentes:

\section{COPIAR EM EXAME}

$\mathbf{6 9 , 4 \%}$ dos docentes portugueses consideram que os alunos utilizam materiais não autorizados na realização de provas escritas com alguma frequência (45\%) ou regularmente $(19,4 \%)$.

65,3\% dos docentes portugueses consideram que os alunos copiam numa prova escrita pelas respostas de um colega com alguma frequência (51\%) ou regularmente (14,3\%).

\section{COPIAR EM TRABALHO}

$\mathbf{8 5} \%$ dos docentes portugueses consideram que os alunos copiam partes de trabalhos de outros autores sem os citar com alguma frequência $(39,4 \%)$ ou regularmente $(45,6 \%)$.

$\mathbf{7 8 , 4 \%}$ dos docentes portugueses consideram que os alunos copiam trabalhos da Internet com alguma frequência $(43,4 \%)$ ou regularmente (35\%).

$\mathbf{6 6 , 3 \%}$ dos docentes portugueses consideram que os alunos copiam trabalhos de outros colegas com alguma frequência $(44,1 \%)$ ou regularmente $(22,2 \%)$.

$\mathbf{4 7 , 1 \%}$ dos docentes portugueses consideram que os alunos nunca $(7,3 \%)$ ou raramente $(39,8 \%)$ apresentam o mesmo trabalho em várias disciplinas. 


\section{COMPRAR TRABALHO}

$37,9 \%$ dos docentes portugueses considera que os alunos nunca $(9,9 \%)$ ou raramente (28\%) compram trabalhos a outros colegas. $\mathbf{5 5 , 9 \%}$ dos docentes portugueses afirmam não saber com que regularidade esta prática ocorre.

\section{NÃO DENUNCIAR}

$\mathbf{8 5 , 8 \%}$ dos docentes portugueses consideram que os alunos nunca $(42,7 \%)$ ou raramente $(43,1 \%)$ denunciam fraudes académicas cometidas por colegas.

Os resultados sugerem que, para os docentes, as fraudes mais frequentes estão relacionadas com a realização de trabalhos, o que pode significar uma certa desresponsabilização da intervenção ativa no combate à fraude. Na instância de exame escrito, o docente acompanha a sua realização e é responsável pela vigilância permanente do comportamento do aluno. Mas no caso dos trabalhos, as múltiplas fontes e formas de apropriação indevida de trabalho alheio tornam este processo de fiscalização bastante mais complexo e falível. Há portanto, um reconhecimento subliminar de que a vigilância em provas escritas é mais eficaz do que no caso de trabalhos de investigação. Por outro lado, os docentes parecem ignorar se os alunos compram trabalhos ou se se inventam dados, o que confirma um certo distanciamento em relação à vigilância ativa da eventual fraude. Por fim, a cultura de encobrimento da fraude é reconhecida pelos docentes, que reconhecem quase não existir denúncia entre os alunos.

\subsubsection{Os motivos da fraude}

No contexto deste estudo, pretendeu-se também avaliar o pensamento dos docentes sobre quais os motivos que levariam os alunos a cometer fraude. Para o efeito, foi solicitado que classificassem, 
numa escala que variava entre 1 e 5, a importância de cada um dos mesmos treze motivos potenciais que foram apresentados também aos alunos. A Tabela 23 mostra a importância média atribuída pelos docentes aos motivos que poderão explicar a prática de fraude académica pelos alunos.

\begin{tabular}{|c|c|c|}
\hline & & $\begin{array}{l}\text { Importância média } \\
(1-5)\end{array}$ \\
\hline 1 & Hábito de uma conduta fraudulenta desde o ensino secundário & 3,36 \\
\hline 2 & Assegurar o sucesso a uma disciplina à qual já se reprovou & 3,25 \\
\hline 3 & $\begin{array}{l}\text { Perceção de que a pena, no caso de ser descoberta a fraude, é } \\
\text { pouco significativa }\end{array}$ & 3,19 \\
\hline 4 & Regularidade da prática fraudulenta entre colegas & 3,11 \\
\hline 5 & Passividade dos professores perante situações de fraude & 3,06 \\
\hline 6 & $\begin{array}{l}\text { Insegurança sobre a capacidade de alcançar o sucesso de outra } \\
\text { forma }\end{array}$ & 2,98 \\
\hline 7 & $\begin{array}{l}\text { Falta de conhecimento sobre qual deve ser a boa conduta } \\
\text { académica }\end{array}$ & 2,71 \\
\hline 8 & Pouca relevância prática atribuída aos conteúdos curriculares & 2,69 \\
\hline 9 & Falta de debate sobre o assunto nas aulas com os professores & 2,67 \\
\hline 10 & Carga de trabalho académico & 2,64 \\
\hline 11 & Modalidades de avaliação & 2,58 \\
\hline 12 & Pressão competitiva entre os colegas & 2,27 \\
\hline 13 & Competência pedagógica insuficiente dos professores & 2,25 \\
\hline
\end{tabular}

Tabela 23. Motivos para cometer Fraude Académica (opinião dos docentes) 
Segundo a perceção dos docentes, o comportamento fraudulento no ensino pré-universitário prolongado no ensino superior é o motivo mais relevante para explicar a conduta transgressora dos alunos. É também atribuída causa relevante à reprovação passada e à aparente impunidade da prática. Ou seja, os docentes tendem a justificar a prática fraudulenta do aluno com a sua insegurança, a cultura de fraude e a leveza aparente da punição. Já os motivos menos relevantes para cometer fraude são a competência pedagógica insuficiente dos professores e a pressão competitiva entre os colegas. Efetivamente, os motivos relacionados com a dimensão pedagógica e curricular são considerados menos relevantes, embora com uma exceção interessante: a passividade dos professores perante situações de fraude é reconhecida como um motivo importante, o que pode indiciar uma autocrítica subjacente sobre a postura dos docentes perante a fraude ou possibilidade de fraude dos alunos. Esta autocrítica pode, no entanto, também ter subentendida uma crítica à política da instituição de ensino que não incentiva a ação vigilante por parte do corpo docente ou cria mecanismos eficazes de resposta perante a fraude, provocando uma reação negligente entre os docentes.

A comparação da opinião dos docentes com a opinião dos alunos revela convergências e divergências interessantes. As perceções sobre a importância dos motivos são variáveis, não evidenciando uma tendência clara que diferencie os dois grupos. A dissonância é mais significativa nos motivos carga de trabalbo académico e modalidades de avaliação, aos quais os alunos atribuem, como seria de esperar, mais poder explicativo da prática fraudulenta. Já os docentes tendem a valorizar mais do que os alunos a perceção sobre a leveza da pena e a regularidade da prática de fraude como motivos para cometê-la. Genericamente, esta comparação permite concluir que os alunos tendem a responsabilizar mais do que os docentes os aspetos pedagógicos relacionados com a exigência 
das formas de avaliação, enquanto os docentes consideram mais relevante do que os alunos a impunidade percecionada. Ou seja, os alunos tendem a culpabilizar os docentes e os docentes tendem a culpabilizar a instituição.

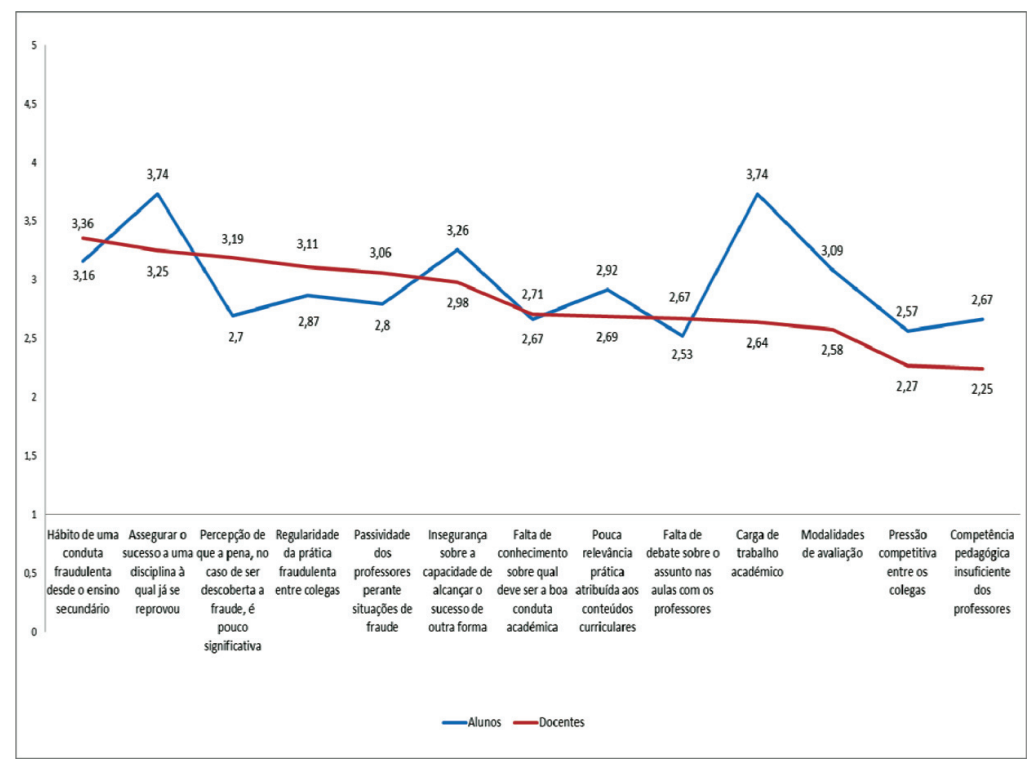

Gráfico 13. Perceção sobre Motivos da Fraude Académica (alunos e docentes)

Quando analisadas estas opiniões dos docentes à luz dos seus níveis de satisfação académica, de sensibilidade e de intolerância à fraude, os dados revelam que à medida que aumenta a sensibilidade à fraude (ISF), aumenta a importância atribuída à cultura de fraude e à ignorância dos alunos como motivos que a determinam ${ }^{52}$. Por outro lado, à medida que diminui a satisfação académica dos docentes (ISA), aumenta a importância atribuída à passividade dos professores

52 Os resultados dos testes estatísticos estão incluídos no ANEXO 4.10. 
como motivo que permite a prática fraudulenta. Este resultado sugere que a insatisfação dos docentes talvez possa estar eventualmente também associada ao reconhecimento de uma atitude geral de inação por parte dos colegas docentes em relação à fraude.

À imagem da análise efetuada para os alunos, também no caso dos docentes procurou-se avaliar a possibilidade de agrupar os motivos em conjuntos que representassem categorias homogéneas de motivos, procedendo para o efeito à análise fatorial exploratória dos dados ${ }^{53}$. A análise sugeriu o agrupamento dos trezes motivos nos mesmos 4 fatores que já haviam sido identificados com os dados da amostra de aluno. Estes fatores estão organizados segundo um critério associado às diferentes instâncias com as quais o aluno se relaciona, distinguindo o círculo interior da relação consigo mesmo e com os colegas, de um círculo intermédio da relação com o curso, até ao círculo exterior da relação com a instituição. Assim, os fatores são mais uma vez classificados nos seguintes termos:

\section{Fator 1 - Práticas pedagógicas (nível curricular) \\ Fator 2 - Cultura de fraude (nível institucional) \\ Fator 3 - Insegurança (nível individual) \\ Fator 4 - Ignorância (nível individual)}

Quando comparados estes quatro fatores - que agrupam quatro categorias de motivos - com o ISF, o IIF e o ISA, os resultados mostram que os docentes tendencialmente mais sensíveis e intolerantes à fraude (com ISF e IIF mais altos) tendem a valorizar mais a ignorância dos alunos como motivador da prática fraudulenta ${ }^{54}$. Isto significa que os docentes mais predispostos a combater a frau-

53 Os resultados da Análise Fatorial Exploratória estão incluídos no ANEXO 4.11.

${ }^{54}$ Fator 4: Coeficientes de Correlação de Spearman 0,143 com ISF (significativo ao nível de 1\%) e 0,095 com IIF (significativo ao nível de 1\%) 
de tendem a responsabilizar os próprios alunos pela transgressão. Por outro lado, à medida que diminui a satisfação académica dos docentes (ISA mais baixos), aumenta a importância que por eles é atribuída à cultura de fraude como facilitadora da prática transgressora $^{55}$. Este resultado sugere que os docentes menos satisfeitos com a carreira e com a instituição tendem também a responsabilizar o plano institucional pela prática de fraude entre alunos.

Em síntese, os resultados sugerem que os docentes tendem a atribuir as causas da prática fraudulenta ao próprio aluno que a comete, por insegurança ou por hábito, desvalorizando a dimensão pedagógica e curricular associada com a carga de trabalho letivo, as modalidades de avaliação ou a competência dos professores. Esta visão parece ser contrariada pela perceção dos alunos que responsabilizam em primeira instância as características das próprias disciplinas. Embora discutível, esta dissonância merece reflexão sobre a forma como os docentes percecionam os determinantes da fraude académica, a fim de que a própria política institucional possa encontrar soluções adequadas às suas causas mais prováveis.

\subsubsection{Os inibidores da fraude}

Tal como no inquérito aos alunos, também se questionou os docentes sobre a importância que atribuíam, numa escala que varia entre 1 e 5, a catorze potenciais inibidores da fraude académica cometida por alunos. Na Tabela 24 apresentam-se os inibidores ordenados segundo a importância decrescente atribuída pelos docentes.

55 Fator 2: Coeficiente de Correlação de Spearman -0,149 (significativo ao nível de $1 \%)$ 
2 Envolvimento dos estudantes na divulgação de boas práticas académicas

5 Sessões de esclarecimento promovidas pela escola sobre a boa conduta académica

6 Utilização de mecanismos de vigilância e de deteção eletrónica de fraude

7 Frequência de programas de desenvolvimento de competências académicas

11 Entrega de uma declaração de autoria/ originalidade dos trabalhos apresentados para avaliação

12 Frequência de disciplinas sobre Ética

13 Divulgação no ambiente escolar do nome dos alunos que praticaram fraudes

Tabela 24. Inibidores da Fraude Académica (opinião dos docentes)

Segundo os resultados, na opinião dos docentes, os inibidores mais eficazes no combate à fraude académica são o agravamento das penas para conduta académica fraudulenta, o envolvimento dos estudantes na divulgação de boas práticas académicas e a divulgação de um Código de Conduta da escola, privilegiando claramente uma política institucional mais afirmativa na punição e na informação. Já os inibidores menos relevantes são, a na opinião dos docentes, a 
garantia de anonimato na denúncia de comportamentos fraudulentos dos colegas estudantes, a divulgação no ambiente escolar do nome dos alunos que praticaram fraudes e a frequência de disciplinas sobre Ética, desvalorizando o incentivo à denúncia e a formação de banda larga sobre o tema. Os resultados podem ainda ser sistematizados nos seguintes termos mais concretos:

. 89,5\% dos docentes consideram que o agravamento das penas é um inibidor importante $(34,4 \%)$ ou mesmo muito importante (55\%)

. 76,5\% dos docentes consideram que impedir telemóveis ligados na sala onde se realizam exames é um inibidor importante $(37,5 \%)$ ou mesmo muito importante (39\%)

. 71,5\% dos docentes consideram que utilizar mecanismos de vigilância e de deteção eletrónica de fraude é um inibidor importante $(38,8 \%)$ ou mesmo muito importante $(32,7 \%)$

. $43,2 \%$ dos docente consideram nada importante $(9,8 \%)$ ou pouco importante $(33,4 \%)$ a frequência de disciplinas sobre Ética como fator inibidor da fraude

. 34,2\% dos docente consideram nada importante (10,2\%) ou pouco importante (24\%) a existência de uma relação de proximidade com os professores como fator inibidor da fraude $(41,4 \%$ considera, neste contexto, essa relação importante)

Quando comparadas as opiniões dos docentes com as opiniões dos alunos, constata-se que uma das maiores dissonâncias entre elas refere-se ao inibidor mais valorizado pelos alunos e que é, simultaneamente, um elemento essencial do processo educativo e relacional: a existência de uma relação de proximidade entre professores e alunos. Os alunos também valorizam significativamente mais do que os docentes a garantia de anonimato na denúncia, enquan- 
to, pelo contrário, atribuem comparativamente aos docentes menos importância à divulgação de um Código de Conduta da escola $\mathrm{e}$ à promoção de sessões de esclarecimento sobre a boa conduta académica. Estes resultados sugerem que existe uma diferença relevante de perceções entre docentes e alunos sobre como combater eficazmente a fraude académica. Os docentes valorizam mais do que os alunos as soluções de formação e de informação, enquanto os alunos parecem reclamar uma relação mais personalizada com a instituição que os docentes não parecem reconhecer como prioritária. O Gráfico 14 apresenta esses resultados comparativos.

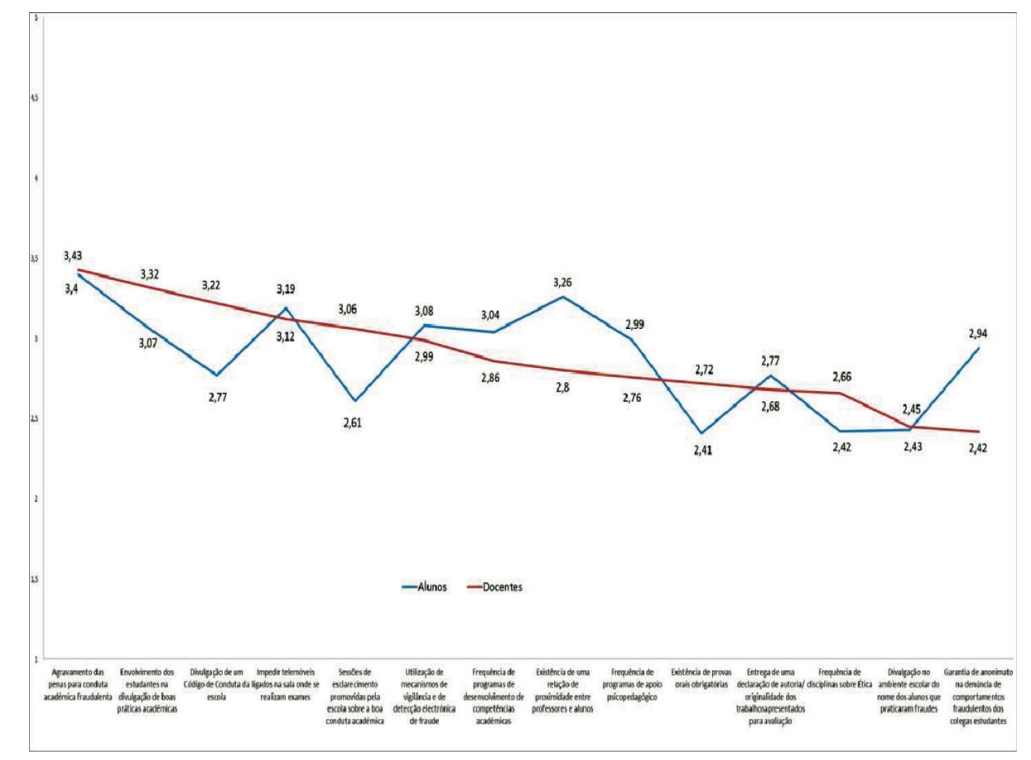

Gráfico 14. Perceção sobre Inibidores da Fraude Académica (alunos e docentes)

Pode também analisar-se a opinião dos docentes sobre os inibidores da fraude à luz da sua satisfação académica e da sensibilidade e intolerância à fraude ${ }^{56}$. Nesse contexto, os dados sugerem que os

56 Os resultados dos testes estatísticos estão incluídos no ANEXO 4.12. 
docentes mais sensíveis à fraude (ISF mais elevado) consideram mais importante a necessidade de esclarecimento e envolvimento dos alunos, como inibidor do comportamento fraudulento. Por outro lado, os docentes com uma prática mais intolerante (IIF mais elevado), tendem a considerar mais necessário o agravamento das penas e o recurso a mecanismos de controlo mais eficazes. Por fim, os docentes mais satisfeitos (ISA mais elevado) tendem a valorizar essencialmente as soluções de formação e de desenvolvimento pessoal dos alunos, como fatores inibidores e preventivos da fraude académica.

Tal como nos motivos da fraude, a eventual existência de categorias que agrupem os inibidores estudados pode facilitar a sua tradução em políticas e soluções coerentes de combate à fraude académica. Para averiguar essa possibilidade, tal como no caso dos alunos, foi efetuada a análise fatorial exploratória dos $\operatorname{dados}^{57}$, a qual sugeriu existirem, subjacente aos catorze inibidores considerados, os mesmos 3 fatores identificados na amostra de alunos. Este agrupamento dos inibidores parece ter como critério de diferenciação entre eles o tipo de estratégia de combate à fraude, podendo os fatores ser designados nos mesmos seguintes termos em que foram designados os fatores encontrados com base nas respostas dos alunos:

\section{Fator 1 - Estratégias de dissuasão Fator 2 - Estratégias de informação \\ Fator 3 - Estratégias de apoio pedagógico}

A organização dos inibidores nestes três fatores sugere a existência de três eixos possíveis de organização das políticas de combate institucional à fraude. Um primeiro eixo que privilegia a criação e o desenvolvimento de mecanismos de dissuasão, baseados num sistema de denúncia e castigo da fraude académica. Um segundo

57 Os resultados da Análise Fatorial Exploratória estão incluídos no ANEXO 4.13. 
eixo que privilegia a formação e a educação dos alunos sobre a boa conduta académica. E um terceiro eixo que privilegia a qualidade da relação pedagógica com o aluno, materializada em políticas de reforço da proximidade e do comprometimento do aluno com a instituição. Os resultados sugerem que os docentes tendem a desvalorizar este terceiro eixo, ao contrário dos alunos que o valorizam superiormente.

Embora os docentes privilegiem a formação e os mecanismos dissuasores como meios prioritários de combate à fraude, os alunos parecem alertar subliminarmente para os perigos de um distanciamento crescente nas relações pedagógicas e da despersonalização das relações académicas. A incompreensão dos motivos profundos que explicam a conduta transgressora dos alunos e dos fatores que podem combatê-la eficazmente é um indiscutível obstáculo ao êxito do processo de ensino-aprendizagem, cujo fracasso se reflete inevitavelmente em termos pessoais e sociais. O papel dos docentes e das instituições é central e decisivo neste combate. Ignorar o ponto de vista do aluno sobre estes aspetos é um erro que pode conduzir a políticas equivocadas, medidas inúteis e mal entendidos contraproducentes.

\subsection{A reação dos professores perante a fraude dos alunos}

Neste estudo, a sensibilidade dos docentes à fraude refere-se à forma como interpretam a sua gravidade, enquanto a sua intolerância refere-se à forma como se dispõem a agir perante ela. Complementarmente a estas dimensões de análise, buscou-se também identificar as respostas concretas que os docentes dão perante a deteção da fraude. Para o efeito, foram previamente identificadas cinco respostas-tipo, variando em grau de envolvimento institucional do docente no processo de combate à fraude: não faz nada; adverte o aluno; 
penaliza a avaliação, informa o coordenador do curso; ou comunica à direção da escola. No questionário foi perguntado do docente qual desta - ou destas - foi - ou seria - a sua reação quando confrontado, na sua atividade docente, com cada uma de seis práticas distintas de fraude (todas práticas ativas, duas em exame e quatro em trabalho).

Dada a natureza destas perguntas, foi permitido que os docentes assinalassem mais do que uma resposta, admitindo naturalmente que um docente pode dar várias respostas simultâneas perante a deteção de fraude académica. Na Tabela 25 são apresentados os resultados, com a percentagem de docentes que admitiu cada tipo de reação perante cada uma das seis práticas avaliadas.

\begin{tabular}{|c|c|c|c|c|c|}
\hline & $\begin{array}{l}\text { Adverte } \\
\text { o aluno }\end{array}$ & $\begin{array}{l}\text { Penaliza a } \\
\text { avaliação }\end{array}$ & $\begin{array}{l}\text { Informa } \\
\text { coordenador } \\
\text { de curso }\end{array}$ & $\begin{array}{l}\text { Comunica à } \\
\text { direção da } \\
\text { escola }\end{array}$ & $\begin{array}{c}\text { Não faz } \\
\text { nada }\end{array}$ \\
\hline Copiar por um colega em exame escrito & $56,7 \%$ & $56,3 \%$ & $29,7 \%$ & $4,8 \%$ & $0,2 \%$ \\
\hline $\begin{array}{l}\text { Utilizar materiais não autorizados durante a } \\
\text { realização de exame escrito }\end{array}$ & $53,7 \%$ & $62,3 \%$ & $30,0 \%$ & $5,8 \%$ & $0,3 \%$ \\
\hline Apresentar trabalho plagiado & $26,8 \%$ & $78,7 \%$ & $30,7 \%$ & $16,9 \%$ & $0,2 \%$ \\
\hline $\begin{array}{l}\text { Assumir coautoria de trabalho no qual não } \\
\text { participou }\end{array}$ & $30,8 \%$ & $76,6 \%$ & $21,5 \%$ & $4,1 \%$ & $2,5 \%$ \\
\hline $\begin{array}{l}\text { Apresentar o mesmo trabalho que já havia } \\
\text { apresentado em outra disciplina }\end{array}$ & $29,1 \%$ & $66,6 \%$ & $25,3 \%$ & $6,6 \%$ & $3,8 \%$ \\
\hline Apresentar trabalho com dados falsos & $27,0 \%$ & $72 \%$ & $27,3 \%$ & $12,9 \%$ & $0,4 \%$ \\
\hline
\end{tabular}

Tabela 25. Reação dos docentes perante a deteção de Fraude Académica

Os resultados mostram que a principal resposta dos docentes perante a deteção de situações de fraude cometidas por alunos é a penalização da avaliação. A advertência ao aluno também é comum, embora, no caso da submissão de um trabalho plagiado haja mais docentes a informar o coordenador de curso do que a advertir o aluno. Aparentemente, a apresentação do mesmo trabalho que já havia apresentado em outra disciplina é a fraude com reação mais suave por parte dos docentes, havendo $3,8 \%$ que afirmam não reagir perante 
este tipo de fraude. Os resultados parecem confirmar uma baixa predisposição dos docentes para a denúncia, já que menos de um terço dos docentes transfere para a esfera institucional a resposta à fraude.

Genericamente, os resultados sugerem que a inatividade do docente não é uma opção perante a fraude observada e que na generalidade dos casos ela se reflete na penalização da classificação do aluno. É curioso que em sede de exame pouco mais de metade dos docentes adverte o aluno, mas no caso dos trabalhos, menos de um terço o faz. Haverá porventura uma cultura de penalização sem advertência que poderá limitar o efeito educativo da punição, não atuando como inibidor duradouro da prática transgressora.

\subsection{Os inibidores da denúncia segundo os professores}

A eficácia do combate às práticas de fraude académica entre alunos do ensino superior depende do envolvimento de todos os agentes implicados nesse fenómeno, nomeadamente, os alunos, as suas famílias, os docentes, os funcionários e a própria instituição. No entanto, os efeitos mais nocivos da fraude, relacionados com a distorção na classificação do desempenho académico, podem ser minimizados através da ação afirmativa dos docentes na prevenção, vigilância, deteção e denúncia da fraude. É a eles, enquanto decisores sobre a avaliação dos alunos, que a prática fraudulenta se destina e a quem os alunos pretendem iludir ou enganar. É por isso fundamental, no combate à fraude, que os docentes estejam predispostos a proteger o mais possível a justiça da avaliação, tendo uma atitude vigilante e consequente. A denúncia da fraude, no contexto institucional, constitui uma resposta para contrariar este fenómeno do ponto de vista sistémico.

$O$ efeito perverso da injustiça na avaliação pode ser evitado pelo docente no âmbito da sua relação bilateral com o aluno transgressor, porém a denúncia permite que o ato seja entendido e combatido no 
plano institucional, com efeitos dissuasores e formativos porventura mais eficazes. Embora nem sempre necessária ou desejável, a denúncia da fraude dos alunos pelos docentes é, em geral, um sinal de transparência, exigência e eficácia da política institucional de combate à fraude. A predisposição dos docentes para enfrentarem e inibirem os efeitos propagadores da injustiça da fraude pode ser avaliada através da sua predisposição para a denúncia. Pode haver, no entanto, diversas barreiras e desincentivos que provocam a inibição dessa denúncia, nem sempre explicada pela opção por medidas alternativas que se creem mais eficazes.

Assim, procurou-se também entender quais os fatores que poderão inibir os docentes de denunciar a fraude observada, solicitando que classificassem oito possíveis causas da não denúncia numa escala que varia entre 1 (nada inibidor) até 4 (muito inibidor). A Tabela 26 apresenta os resultados médios das respostas dos docentes e, dado tratar-se dos fatores poderão inibir o seu comportamento, inclui-se também a sua correlação com a sensibilidade à fraude (ISF), a intolerância à fraude (IIF) e o seu grau de satisfação académica (ISA).

\begin{tabular}{|c|c|c|c|c|c|}
\hline & & \multirow{2}{*}{$\begin{array}{l}\text { Grau de } \\
\text { inibição } \\
\text { (1-4) }\end{array}$} & \multicolumn{3}{|c|}{ Correlação Spearman } \\
\hline & & & $\begin{array}{c}\text { ISF } \\
\text { (sensibilidade) } \\
\end{array}$ & $\begin{array}{c}\text { IIF } \\
\text { (intolerância) }\end{array}$ & $\begin{array}{c}\text { ISA } \\
\text { (satisfação) }\end{array}$ \\
\hline 1 & Perceção de que a denúncia não produzirá efeitos punitivos & 2,67 & & & $-0.243 * *$ \\
\hline 2 & Burocracia processual & 2,66 & $-0.043^{*}$ & $-0.046^{*}$ & $-0.183 * *$ \\
\hline 3 & $\begin{array}{l}\text { Desconhecimento dos procedimentos a adotar em caso de } \\
\text { deteção }\end{array}$ & 2,64 & & $-0.102 * *$ & $-0.135^{* *}$ \\
\hline 4 & Insuficiente apoio institucional à denúncia & 2,63 & & & $-0.346^{* *}$ \\
\hline 5 & $\begin{array}{l}\text { Perceção de que a sanção não corrige o comportamento } \\
\text { dos alunos }\end{array}$ & 2,43 & & $-0.043^{*}$ & $-0.109^{* *}$ \\
\hline 6 & Contribuição para deterioração da relação com alunos & 2,10 & $-0.068 * *$ & $-0.100 * *$ & $-0.053 * *$ \\
\hline 7 & Severidade excessiva da eventual punição & 2,09 & $-0.096 * *$ & $-0.104 * *$ & \\
\hline 8 & Eventual prejuízo da reputação do docente & 1,92 & $-0.042^{*}$ & $-0.081 * *$ & $-0.090 * *$ \\
\hline
\end{tabular}

Tabela 26. Inibidores da Denúncia da Fraude Académica pelos Docentes 
As respostas dos docentes claramente sugerem uma responsabilização da instituição, dado o reconhecimento da presença destes fatores no seu contexto académico. Os fatores mais inibidores, tais como a perceção de que a denúncia não produzirá efeitos punitivos ou a burocracia processual, são indicadores de que haverá um desincentivo institucional passivo à denúncia. A relevância destes fatores institucionais objetivos é confirmada pela menor importância atribuída pelos docentes a fatores de avaliação subjetiva, tais como o prejuízo da sua reputação ou a severidade excessiva da eventual punição.

Tal como era previsível, à medida que aumenta a sensibilidade e a intolerância do docente à fraude (ISF e IIF mais elevados), diminui a importância que ele atribui à generalidade dos inibidores, pois é naturalmente menos vulnerável ao seu efeito dissuasor da denúncia. Um docente com uma atitude mais intolerante à fraude tenderá a deixar-se inibir menos por barreiras institucionais, independentemente da sua maior ou menor presença no contexto académico onde exerce a sua atividade docente. Por outro lado, à medida que diminui o grau de satisfação académica dos docentes (ISA mais baixo), aumenta a importância que atribuem ao insuficiente apoio institucional e à incapacidade punitiva da denúncia como fatores que inibem o docente de denunciar a fraude observada. Isto pode significar que a insatisfação académica dos docentes pode estar de alguma forma relacionada também com a perceção de que a política da instituição a que pertencem é ineficaz ou constitui mesmo um impedimento ao eficaz combate à injustiça avaliativa e à fraude que a pode provocar.

Para tentar compreender se estes inibidores de facto se podem distinguir entre si de acordo com o grau de importância que os docentes lhes atribuem, procedeu-se à análise fatorial exploratória dos dados, no sentido de avaliar se os oito fatores poderão ser coerentemente agrupados em categorias homogéneas ${ }^{58}$. A análise

58 Os resultados da Análise Fatorial Exploratória estão incluídos no ANEXO 4.14. 
sugere a extração de dois fatores, distinguindo entre inibidores de ordem institucional e inibidores de ordem pessoal, agregados nos seguintes termos:

\section{Fator 1 - Inibidores Institucionais}

(agrega no mesmo fator a burocracia processual, o desconbecimento dos procedimentos a adotar em caso de deteção, a perceção de que a denúncia não produzirá efeitos punitivos, a perceção de que a sanção não corrige o comportamento dos alunos e o insuficiente apoio institucional à denúncia)

Fator 2 - Inibidores Pessoais

(agrega no mesmo fator o eventual prejuizo da reputação do docente, a contribuição para deterioração da relação com alunos e a severidade excessiva da eventual punição)

No caso dos Inibidores Institucionais a denúncia é desincentivada por uma descrença na eficácia dos processos administrativos e no comprometimento da instituição com a punição efetiva do transgressor. No caso dos Inibidores Pessoais, o docente é desincentivado a denunciar com base nos efeitos pessoais - de impacto no aluno - e relacionais - de impacto na relação do docente com o aluno - que a denúncia possa provocar. Quando comparados os dois fatores com o ISF, o IIF e o ISA, verifica-se que a importância atribuída aos Inibidores Institucionais aumenta significativamente à medida que diminui a satisfação académica dos docentes ${ }^{59}$, confirmando a suspeita de que a sua satisfação poderá ser parcialmente determinada pela sua perceção sobre a política institucional. Já os Inibidores Pessoais tendem a ser mais valorizados à medida que

59 Coeficiente de Correlação de Spearman -0,305 (significativo ao nível de 1\%). 
diminui a sensibilidade e a intolerância dos docentes à fraude ${ }^{60}$, sugerindo que a permissividade dos docentes será maior naqueles mais permeáveis à interferência, nos seus critérios de decisão, de uma apreciação subjetiva sobre os efeitos relacionais da exposição da fraude.

Foi também dada possibilidade aos docentes de se pronunciarem livremente sobre outros inibidores da denúncia da fraude não contemplados no questionário. Foram efetuados 175 comentários de natureza diversa entre si, mas entre os quais é possível identificar as seguintes cinco dimensões de inibidores da denúncia por parte dos docentes:

. crença de que a fraude é melhor combatida sem denúncia

. crença de que a denúncia é institucionalmente inconsequente

. dificuldade em fazer prova de ocorrência de fraude

. desinteresse dos docentes

. preocupação com os alunos

No Quadro 4 são apresentadas algumas dessas opiniões dos docentes, agregadas nestas categorias de motivos para não denunciarem a fraude cometida por alunos.

60 Coeficientes de Correlação de Spearman -0,091 (significativo ao nível de 1\%) com ISF e -0,114 com IIF (significativo ao nível de 1\%) 


\begin{tabular}{|c|c|}
\hline Fraude é melhor combatida sem denúncia & A denúncia é institucionalmente inconsequente \\
\hline $\begin{array}{l}\text { - "A anulação da prova pelo docente é suficiente. Funciona } \\
\text { como penalização e como dissuasor de futuras tentativas." } \\
\text { - "A convicção de que a abordagem direta aos alunos e a } \\
\text { determinação convincente de uma norma de conduta } \\
\text { disciplinar em ambiente letivo impede, ou elimina, esse tipo } \\
\text { de comportamentos." } \\
\text { - "A perceção de que o próprio professor, nas suas } \\
\text { atribuições, pode ele próprio atribuir uma sanção, o que é } \\
\text { geralmente a forma mais sensata e prática de agir." } \\
\text { - "A punição não educa e como tal não corrige nem resolve o } \\
\text { problema de fundo, como tal não tem valor exceto nos casos } \\
\text { cuja capacidade de intervenção se esgotou para garantir que } \\
\text { o aluno não tira dividendos da fraude." } \\
\text { - "Apostar na prevenção e não na punição é fundamental." } \\
\text { - "Considerarem suficiente a pena que aplicam ao aluno." } \\
\text { - "Crença/desejo que haja espaço para o aluno corrigir o seu } \\
\text { comportamento, sem ter de ser sancionado } \\
\text { institucionalmente e de forma mais explicita." } \\
\text { - "É assunto a tratar entre aluno e docente, numa 19 vez. A } \\
\text { continuar a prática propor a quem de direito a reprovação do } \\
\text { infrator." } \\
\text { - "O docente entende que pode lidar sozinho com a situação, } \\
\text { penalizando os alunos fraudulentos e evitando o uso de } \\
\text { mecanismos institucionais." }\end{array}$ & $\begin{array}{l}\text { - "Em todos os estabelecimentos de ensino em que lecionei o } \\
\text { único tipo de sanção que se aplica é a penalização na nota. } \\
\text { As próprias instituições não dão muita importância à fraude } \\
\text { por parte do aluno." } \\
\text { - "Falta de clareza nos procedimentos e sanções tolerantes." } \\
\text { - "Indiferença dos órgãos da instituição." } \\
\text { - "Apoio/cobertura institucional a quem paga a propina." } \\
\text { - "Inexistência de regulamentação adequada." } \\
\text { - "Inexistência de comissões externas à Instituição." } \\
\text { - "Não existem verdadeiros mecanismos de punição. Num } \\
\text { caso a docente foi informada que o caso era um desrespeito } \\
\text { dos direitos de autor, que teria de ser tratado nos tribunais, } \\
\text { com o autor a acusar o aluno de plágio!!" } \\
\text { - "Pressão da universidade para que não se reprovem } \\
\text { alunos." } \\
\text { - "A culpa sempre morre solteira." }\end{array}$ \\
\hline Dificuldade da prova & Preocupação com os alunos \\
\hline $\begin{array}{l}\text { - "Ausência de prova jurídica." } \\
\text { • "Dificuldade de provar quando se trata de cópia num exame } \\
\text { escrito por outro colega." } \\
\text { - "Dificuldade na obtenção de meio de prova, salvo em casos } \\
\text { evidentes de plágio." }\end{array}$ & $\begin{array}{l}\text { - "Prejudicar excessivamente o futuro do aluno, que muitas } \\
\text { vezes nem tem noção de que o que está a fazer é fraude." } \\
\text { - "Complacência relativamente ao aluno se este se revelar } \\
\text { interessado pela disciplina fora dos momentos de avaliação." } \\
\text { - "Evitar situações de tensão e conflito associados aos }\end{array}$ \\
\hline $\begin{array}{l}\text { - "Falta de provas para corroborar o juízo do professor." } \\
\text { - "Há fraudes que dão muito trabalho provar e isso também } \\
\text { inibe o trabalho "detetivesco» implícito." } \\
\text { - "Um fator muito importante é: como provar a fraude duma } \\
\text { forma legal, se as testemunhas que estão por exemplo numa } \\
\text { sala de exame são outros alunos!" }\end{array}$ & $\begin{array}{l}\text { processos de provar a fraude e confrontar o aluno." } \\
\text { - "Incerteza quanto à justiça dos métodos de Avaliação." } \\
\text { - "Desconhecimento generalizado de como reagir e receio de } \\
\text { um indireto apelo ao policiamento entre pares e à denúncia } \\
\text { anónima." } \\
\text { - "Exigência e punição contra fraudes não ser universal e } \\
\text { coerente nas diversas instituições de ensino superior; Falta de } \\
\text { meios para detetar fraudes." }\end{array}$ \\
\hline
\end{tabular}




\begin{tabular}{|c|c|}
\hline \multicolumn{2}{|c|}{ Desinteresse dos docentes } \\
\hline $\begin{array}{l}\text { - "A falta de interesse nos alunos, na escola e na ética e } \\
\text { muitíssimo maior preocupação em manter o "tacho" ao final do } \\
\text { mês sem ter trabalho algum! "Deixa rolar que eu quero é } \\
\text { manter o meu estatuto, quem vier atras que feche a porta!"" } \\
\text { - "Assegurar uma boa produtividade do professor." } \\
\text { - "Ausência de prática de denúncia, ou seja, não querer sero } \\
\text { único a denunciar quando habitualmente ninguém o faz, em } \\
\text { igualdade de circunstâncias." } \\
\text { - "Avaliação do professor pelos alunos." } \\
\text { - "Comodismo." } \\
\text { - "Docentes que na sua vida profissional cometem fraudes } \\
\text { muito mais graves que os alunos e são premiados em vez de } \\
\text { penalizados." } \\
\text { - "Falta de cultura ética dos docentes." }\end{array}$ & $\begin{array}{l}\text { - "Há por parte de alguns docentes a ideia de que não há } \\
\text { necessidade de se aborrecerem com estas questões que tendem } \\
\text { a considerar de menor relevância. Demitem-se por isso de ser } \\
\text { vigilantes de situaçães de fraude." } \\
\text { - "Negligência devido ao sentimento de que vigiar provas não é } \\
\text { uma tarefa da responsabilidade dos docentes e necessidade de } \\
\text { ocupar o tempo da vigilância com outras tarefas." } \\
\text { - "Perseguição do docente pelos visados, familiares e amigose } \\
\text { repercussões negativas na avaliação de desempenho do } \\
\text { docente decorrente da avaliação dos alunos." } \\
\text { - "Aceitação cultural do fenómeno." } \\
\text { - "Achar que não é um problema grave." } \\
\text { - "Há o risco do processo de denúncia se centrar no docente } \\
\text { (exposição, desrespeito, incompetência, escassa afetividade)." }\end{array}$ \\
\hline
\end{tabular}

Quadro 4. Inibidores da Denúncia da Fraude Académica pelos Docentes (opiniões dos docentes)

As opiniões manifestadas pelos docentes sugerem claramente que, por um lado, prevalece uma preocupação com os efeitos nocivos da própria denúncia, considerada improdutiva ou até contraproducente. Para estes docentes, a fraude é melhor combatida na relação direta do docente com o aluno, de forma bilateral, porventura privada, que acreditam gerar resultados mais sustentáveis. Por outro lado, os doentes também atribuem responsabilidades às instituições que incentivam as boas classificações na avaliação dos alunos e não implementam mecanismos eficazes e credíveis de inibição e repressão da fraude que facilitem o processo de denúncia e providenciem um acompanhamento consequente desses casos. Os docentes também não se inibem de responsabilizar a própria classe docente, reconhecendo a que prevalece em muitos casos o desinteresse do docente pelo combate à fraude, quer seja pela prioridade que confere à atividade de investigação, quer seja pelo receio da denúncia reverter contra si.

Em síntese, os resultados parecem agrupar dois tipos de inibidores da denúncia por parte dos docentes. Os mais relevantes, na 
sua opinião, estão relacionados com um certo grau de desconfiança institucional, de descrença nos processos administrativos e na capacidade ou disponibilidade punitiva da instituição. Os inibidores menos relevantes estão relacionados com as dimensões pessoal e relacional, ou seja, o impacto da punição no aluno e do processo delatório na relação dos alunos com o professor tendem a ser desvalorizados como motivos para evitar a denúncia da fraude. Por outro lado, também o foco da carreira académica na produção científica e políticas institucionais incapazes de responder eficazmente à ameaça da prática fraudulenta parecem contribuir para a consolidação de uma cultura de tolerância e legitimação da fraude entre os docentes. 


\section{CAPÍTULO IV \\ RESUMO DOS RESULTADOS}

Este capítulo é uma sistematização dos principais resultados apresentados e discutidos nos Capítulos II e III, destacando também os resultados obtidos nas subamostras de cada uma das grandes áreas científicas consideradas no estudo das perceções dos alunos sobre a fraude académica.

\subsection{Resumo dos Resultados Globais dos Alunos}

\section{FREQUÊNCIA}

Perceção sobre a frequência de fraude

$46,4 \%$ com alguma frequência

$23,2 \%$ regularmente

Perceção sobre a fraude é maior em alunos:

. mulheres

. cujo percurso pré-universitário foi feito maioritariamente em escolas privadas

. que não reprovaram

. com mais inscrições no ensino superior

. com média mais alta

. que dizem não existir regulamento disciplinar na sua instituição

. cujas mães têm escolaridade superior

. dirigentes associativos

Fraudes mais frequentes

Utilizar materiais não autorizados na realização de provas escritas $(2,95 / 4)$

Copiar numa prova escrita pelas respostas de um colega $(2,94 / 4)$

Deixar copiar respostas num exame $(2,81 / 4)$

Fraudes menos frequentes

Comprar trabalhos a outros colegas $(1,6 / 4)$

Comprar trabalhos académicos fora da escola $(1,65 / 4)$ 
Resumo

. Fraudes mais frequentes relacionadas com realização de prova escrita.

. Copiar trabalhos ou assinar sem colaborar é frequente, mas comprar trabalhos é uma prática quase inexistente.

. Apropriação e facilitação mais frequente que simulação.

. Denúncia quase inexistente.

\section{GRAVIDADE}

\section{Fraudes mais graves}

Comprar trabalho a colega $(8,43 / 10)$

Vender aos colegas trabalhos realizados por si próprio $(7,36 / 10)$

Obter a colaboração de familiar $(6,72 / 10)$

\section{Fraudes menos graves}

Apresentar o mesmo trabalho em diferentes disciplinas $(4,18 / 10)$

Permitir que um colega partilhe a autoria formal de um trabalho sem ter participado nele $(4,42 / 10)$

Emprestar a colegas trabalho realizado por si próprio para que estes apresentem como seu (5,62/10)

\section{Categorias de fraude (segundo gravidade)}

Fator 1 - fraude em trabalho

Fator 2 - fraude em exame escrito

Fator 3 - fraude transacional (baseada em transação económica ou afetiva)

\section{Resumo}

. Uma maioria significativa dos alunos reconhece todos os cenários como situação de fraude académica.

- Comprar, obter colaboração ou plagiar trabalho é mais grave do que inventar dados, ou seja, a apropriação do trabalho alheio é mais grave do que a sua verdade substantiva.

. É mais grave apropriar-se de trabalho alheio do que facilitar a apropriação a outro, e é mais grave facilitar a apropriação do trabalho do que simulá-lo.

\section{IPF PORTUGAL $=4,19 / 10$}

IPF maior nos alunos:

- homens

- cujo percurso pré-universitário foi maioritariamente feito em escolas privadas

- cujo curso que escolheram não foi a primeira opção

- que já reprovaram

- com menor média

- que dizem não existir regulamento disciplinar na sua escola

- que reconhecem existir, mas que não leram o regulamento disciplinar da sua escola

- cujos pais têm maior grau de escolaridade

- cujos agregados familiares têm rendimentos mais elevados

- dirigentes associativos

- mais novos

- com mais inscrições no ensino superior

- que percecionam maior frequência de fraude no seu curso

\section{IPD PORTUGAL $=0,58 / 10$}

IPD maior nos alunos:

- que já leram o regulamento disciplinar da sua escola

- cuja mãe têm menor grau de escolaridade

- com menos inscrições no ensino superior

- que reprovaram a menos disciplinas

- com maior média 


\section{MOTIVOS}

\section{Motivos mais importantes}

Assegurar o sucesso a uma disciplina à qual já se reprovou $(3,74 / 5)$

Carga de trabalho académico $(3,74 / 5)$

Insegurança sobre a capacidade de alcançar o sucesso de outra forma $(3,26 / 5)$

\section{Motivos menos importantes}

Falta de debate sobre o assunto nas aulas com os professores $(2,53 / 5)$

Pressão competitiva entre os colegas $(2,57 / 5)$

Competência pedagógica insuficiente dos professores $(2,67 / 5)$

Falta de conhecimento sobre qual deve ser a boa conduta académica $(2,67 / 5)$

\section{Categorias de motivos}

Fator 1 - práticas pedagógicas (nível curricular)

Fator 2 - cultura de fraude (nível institucional)

Fator 3 - insegurança (nível individual)

Fator 4 - ignorância (nível individual)

\section{Análise}

. Os motivos mais relevantes dizem respeito aos obstáculos para alcançar êxito de outra forma, quer sejam as características do curso ou a insegurança do aluno.

- A predisposição para a fraude pode ser mais estimulada por meio da relação do aluno com a disciplina do que por causa da sua relação com a instituição ou a sua ignorância em relação aos princípios da boa conduta académica, sugerindo uma responsabilização prioritária dos níveis de exigência pedagógica de cada curso como fator que estimula a fraude entre os alunos.

. Os alunos transgressores tendem a externalizar a culpa, responsabilizando a exigência porventura excessiva do curso que frequentam, enquanto os alunos menos transgressores tendem a internalizá-la, responsabilizando o ambiente favorável à fraude e a ignorância do aluno que transgride.

.O aluno tende a substituir-se à instituição no combate à fraude, à medida que a reconhece menos capaz de fazê-lo com eficácia, quer seja na criação de uma cultura desincentivadora da fraude ou na educação dos alunos para uma prática académica exemplar.

. Os resultados sugerem que talvez exista um contexto de carga porventura excessiva de trabalho que favorece a fraude, assim como um descrédito generalizado na eficácia da intervenção institucional para combatê-la.

\section{INIBIDORES}

\section{Inibidores mais importantes}

Agravamento das penas para conduta académica fraudulenta $(3,4 / 5)$

Existência de uma relação de proximidade entre professores e alunos $(3,26 / 5)$

Impedir telemóveis ligados na sala onde se realizam exames $(3,19 / 5)$

\section{Inibidores menos importantes}

Existência de provas orais obrigatórias $(2,41 / 5)$

Frequência de disciplinas sobre Ética $(2,42 / 5)$

Divulgação no ambiente escolar do nome dos alunos que praticaram fraudes $(2,43 / 5)$

\section{Categorias de inibidores}

Fator 1 - estratégias de dissuasão

Fator 2 - estratégias de informação

Fator 3 - estratégias de apoio pedagógico

\section{Análise}

- Apesar do caráter punitivo do agravamento das penas, os resultados parecem sugerir que a relação de proximidade entre aluno e instituição pode efetivamente desincentivar a fraude.

. Os alunos potencialmente mais transgressores valorizam como inibidor a relação de proximidade entre professores e alunos, confirmando a importância das práticas pedagógicas personalizadas e evidenciando os perigos de uma sistema de ensino baseado na quantidade e no afastamento entre os agentes ativos desse processo. 


\subsection{Resumo dos Resultados dos Alunos por Área Científica}

\subsubsection{Economia e Gestão}

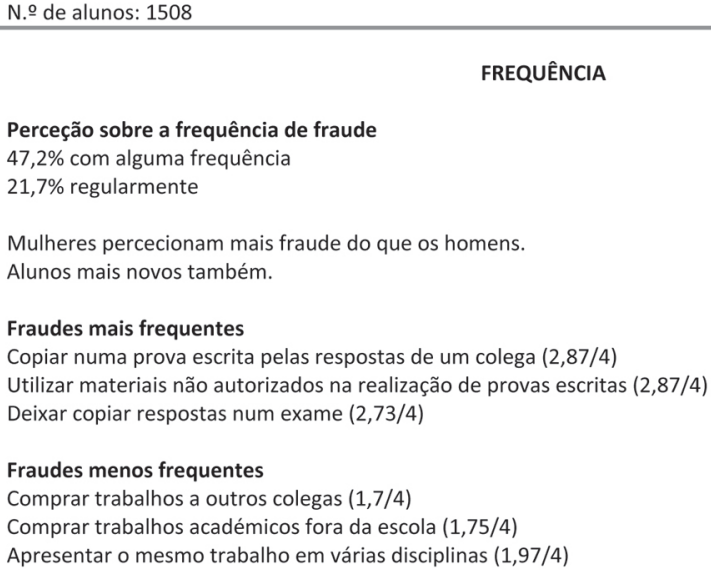

FREQUÊNCIA

Perceção sobre a frequência de fraude

$47,2 \%$ com alguma frequência

$21,7 \%$ regularmente

Mulheres percecionam mais fraude do que os homens.

Alunos mais novos também.

Fraudes mais frequentes

Copiar numa prova escrita pelas respostas de um colega $(2,87 / 4)$

Utilizar materiais não autorizados na realização de provas escritas $(2,87 / 4)$

Deixar copiar respostas num exame $(2,73 / 4)$

Fraudes menos frequentes

Comprar trabalhos a outros colegas $(1,7 / 4)$

Comprar trabalhos académicos fora da escola $(1,75 / 4)$

Apresentar o mesmo trabalho em várias disciplinas $(1,97 / 4)$

\section{GRAVIDADE}

\section{Fraudes mais graves}

Comprar trabalho a colega $(8,26 / 10)$

Vender aos colegas trabalhos realizados por si próprio $(7,20 / 10)$

Consultar materiais não autorizados numa prova escrita $(6,83 / 10)$

\section{Fraudes menos graves}

Apresentar o mesmo trabalho em diferentes disciplinas $(4,19 / 10)$

Permitir que um colega partilhe a autoria formal de um trabalho sem ter participado nele $(4,30 / 10)$

Emprestar a colegas trabalho realizado por si próprio para que estes apresentem como seu $(5,55 / 10)$

Categorias de fraude (segundo gravidade)

Fator 1 - fraude em trabalho

Fator 2 - fraude em exame escrito

Fator 3 - fraude transacional (baseada em transação económica ou afetiva)

\section{IPF ECONOMIA E GESTÃO $=4,33 / 10$}

IPF maior nos alunos:

- homens

- cujo percurso pré-universitário foi maioritariamente feito em escolas privadas

- cujo curso e a instituição que frequentam não foi a primeira escolha

- que já reprovaram

- com menor média

- que afirmam não existir código de boas práticas na sua instituição

- que reconhecem maior incidência de fraude no seu curso 
IPD maior nos alunos:

- com menos inscrições no ensino superior

- com menos reprovações

- com maior média

- que já leram o código disciplinar da instituição

\section{MOTIVOS}

Motivos mais importantes

Assegurar o sucesso a uma disciplina à qual já se reprovou $(3,68 / 5)$

Carga de trabalho académico $(3,62 / 5)$

Insegurança sobre a capacidade de alcançar o sucesso de outra forma $(3,24 / 5)$

\section{Motivos menos importantes}

Pressão competitiva entre os colegas $(2,47)$

Falta de debate sobre $o$ assunto nas aulas com os professores $(2,58 / 5)$

Falta de conhecimento sobre qual deve ser a boa conduta académica $(2,74 / 5)$

\section{Categorias de motivos}

Fator 1 - cultura de fraude (nível institucional)

Fator 2 - práticas pedagógicas (nível curricular)

Fator 3 - insegurança (nível individual)

\section{Análise}

Os alunos com maior propensão para cometer fraude (IPF) tendem a valorizar aspetos relacionados com as características do curso e com a exigência do trabalho como motivadores da fraude, o que parece sugerir uma certa legitimação da fraude justificada por uma exigência excessiva de trabalho. Os resultados também mostram que os alunos tendencialmente mais propensos a cometer fraude tendem a valorizar mais os motivos pedagógicos e de insegurança pessoal como fatores facilitadores da fraude (fatores 2 e 3 ), podendo significar que, nos cursos de economia e gestão, a fraude tende a ser justificada essencialmente por conta das características próprias do curso e da forma como as disciplinas estão organizadas.

\section{INIBIDORES}

\section{Inibidores mais importantes}

Agravamento das penas para conduta académica fraudulenta $(3,38 / 5)$

Existência de uma relação de proximidade entre professores e alunos $(3,3 / 5)$

Impedir telemóveis ligados na sala onde se realizam exames $(3,15 / 4)$

\section{Inibidores menos importantes}

Existência de provas orais obrigatórias $(2,39 / 5)$

Frequência de disciplinas sobre Ética $(2,48 / 5)$

Divulgação no ambiente escolar do nome dos alunos que praticaram fraudes $(2,52 / 5)$

\section{Categorias de inibidores}

Fator 1 - estratégias de dissuasão

Fator 2 - estratégias de informação

Fator 3 - estratégias de apoio pedagógico

\section{Análise}

Apesar do caráter punitivo do agravamento das penas, os resultados parecem sugerir que a relação de proximidade entre aluno e instituição pode efetivamente desincentivar a fraude. IPF explicado principalmente pelos fatores 1 e 2, sugerindo que, nos cursos de economia e gestão, os alunos mais transgressores tendem a sentir-se menos vulneráveis às políticas institucionais preventivas e de educação para um comportamento honesto. Este resultado parece revelar um certo descrédito e ineficácia das políticas institucionais de combate à fraude. 


\subsubsection{Engenharias}

N.o de alunos: 1527

\section{FREQUÊNCIA}

Perceção sobre a frequência de fraude

$41 \%$ com alguma frequência

$21 \%$ regularmente

Mulheres percecionam mais fraude do que os homens.

Fraudes mais frequentes

Utilizar materiais não autorizados na realização de provas escritas $(2,86 / 4)$

Copiar numa prova escrita pelas respostas de um colega $(2,82 / 4)$

Assinar um trabalho de grupo sem ter colaborado na realização do mesmo $(2,72 / 4)$

Copiar partes de trabalhos de outros autores sem os citar $(2,71 / 4)$

Fraudes menos frequentes

Comprar trabalhos a outros colegas $(1,56 / 4)$

Comprar trabalhos académicos fora da escola $(1,64 / 4)$

\section{GRAVIDADE}

\section{Fraudes mais graves}

Comprar trabalho a colega $(8,4 / 10)$

Vender aos colegas trabalhos realizados por si próprio $(7,05 / 10)$

Obter a colaboração de familiar $(6,84 / 10)$

\section{Fraudes menos graves}

Apresentar o mesmo trabalho em diferentes disciplinas (3,56/10)

Permitir que um colega partilhe a autoria formal de um trabalho sem ter participado nele $(4 / 10)$

Emprestar a colegas trabalho realizado por si próprio para que estes apresentem como seu $(5,07 / 10)$

\section{Categorias de fraude (segundo gravidade)}

Fator 1 - fraude individual (baseada na responsabilidade pessoal)

Fator 2 - fraude transacional (baseada em transação económica ou afetiva)

Fator 3 - fraude grupal (baseada na responsabilidade coletiva)

\section{IPF ENGENHARIAS $=4,93 / 10$}

IPF maior nos alunos:

- homens

- que já reprovaram

- com menor média

- que não leram o regulamento de boas práticas da instituição

\section{IPD ENGENHARIAS $=0,42 / 10$}

IPD maior nos alunos:

- homens

- com maior média

- que já leram o regulamento de boas práticas da instituição 


\section{MOTIVOS}

\section{Motivos mais importantes}

Carga de trabalho académico $(3,84 / 5)$

Assegurar o sucesso a uma disciplina à qual já se reprovou $(3,68 / 5)$

Insegurança sobre a capacidade de alcançar o sucesso de outra forma $(3,18 / 5)$

Motivos menos importantes

Pressão competitiva entre os colegas $(2,31 / 5)$

Falta de debate sobre $o$ assunto nas aulas com os professores $(2,47 / 5)$

\section{Categorias de motivos}

Fator 1 - política e cultura de fraude (nível institucional)

Fator 2 - práticas pedagógicas (nível da disciplina)

Fator 3 - pressão para o êxito (nível individual)

\section{Análise}

A predisposição para a fraude pode ser mais estimulada por meio da relação do aluno com a disciplina do que por motivos contextuais ou culturais exógenos a essa relação individual; responsabilização prioritária dos níveis de exigência pedagógica de cada curso como fator que estimula a fraude entre os alunos. IPF maior com fator 2 e 3 , confirmando análise de que os motivos mais críticos se situam ao nível meso e micro da relação com a disciplina e não macro da política e cultura da instituição.

\section{INIBIDORES}

\section{Inibidores mais importantes}

Existência de uma relação de proximidade entre professores e alunos (3,34/5)

Agravamento das penas para conduta académica fraudulenta $(3,22 / 5)$

Impedir telemóveis ligados na sala onde se realizam exames $(3,02 / 5)$

\section{Inibidores menos importantes}

Frequência de disciplinas sobre Ética $(2,18 / 5)$

Existência de provas orais obrigatórias $(2,33 / 5)$

Divulgação no ambiente escolar do nome dos alunos que praticaram fraudes $(2,35 / 5)$

\section{Categorias de inibidores}

Fator 1 - estratégias de dissuasão

Fator 2 - estratégias de informação

Fator 3 - estratégias de apoio pedagógico

\section{Análise}

Apesar do caráter punitivo do agravamento das penas, os resultados parecem sugerir que a relação de proximidade entre aluno e instituição pode efetivamente desincentivar a fraude. IPF explicado principalmente pelo fator 2, o que sugere que estratégias de informação serão as mais relevantes para combater a predisposição para cometer fraude académica. 


\subsubsection{Medicina}

N.o de alunos: 420

\section{FREQUÊNCIA}

Perceção sobre a frequência de fraude

$43,2 \%$ com alguma frequência

$24,6 \%$ regularmente

\section{Fraudes mais frequentes}

Copiar numa prova escrita pelas respostas de um colega $(3,06 / 4)$

Deixar copiar respostas num exame $(3,00 / 4)$

Copiar trabalhos de outros colegas $(3,00 / 4)$

Assinar um trabalho de grupo sem ter colaborado na realização do mesmo $(2,95 / 4)$

Fraudes menos frequentes

Comprar trabalhos a outros colegas $(1,55 / 4)$

Comprar trabalhos académicos fora da escola $(1,65 / 4)$

\section{GRAVIDADE}

\section{Fraudes mais graves}

Comprar trabalho a colega $(8,35 / 10)$

Vender aos colegas trabalhos realizados por si próprio $(7,10 / 10)$

Inventar dados num trabalho escrito $(7,02 / 10)$

Fraudes menos graves

Apresentar o mesmo trabalho em diferentes disciplinas $(3,17 / 10)$

Permitir que um colega partilhe a autoria formal de um trabalho sem ter participado nele $(3,55 / 10)$

\section{Categorias de fraude (segundo gravidade)}

Fator 1 - fraude durante um exame escrito

Fator 2 - fraude na realização e trabalhos

Fator 3 - fraude baseada em transação económica ou afetiva

\section{IPF MEDICINA $=4,05 / 10$}

IPF maior nos alunos:

- homens

- cuja instituição não foi a sua primeira escolha

IPD MEDICINA $=0,44 / 10$

IPD maior nos alunos:

- homens 


\section{MOTIVOS}

\section{Motivos mais importantes}

Carga de trabalho académico $(3,99 / 5)$

Assegurar o sucesso a uma disciplina à qual já se reprovou $(3,76 / 5)$

Insegurança sobre a capacidade de alcançar o sucesso de outra forma $(3,35 / 5)$

Motivos menos importantes

Falta de debate sobre o assunto nas aulas com os professores $(2,08 / 5)$

Falta de conhecimento sobre qual deve ser a boa conduta académica $(2,26 / 5)$

\section{Categorias de motivos}

Fator 1 - política e cultura de fraude (nível institucional)

Fator 2 - práticas pedagógicas (nível da disciplina)

Fator 3 - pressão para o êxito (nível individual)

\section{Análise}

A predisposição para a fraude pode ser mais estimulada por meio da relação do aluno com a disciplina do que por motivos contextuais ou culturais exógenos a essa relação individual. IPF maior com fator 2 e IPD maior com fator 1. O combate à fraude, para alunos de medicina, poderá ser mais eficaz quando direcionado para o nível da disciplina, das práticas pedagógicas e da relação dos alunos com professores. A disponibilidade para a denúncia, por seu lado, parece atuar como um compensador das insuficiências de política institucional de combate à fraude reconhecidas pelos alunos.

\section{INIBIDORES}

\section{Inibidores mais importantes}

Agravamento das penas para conduta académica fraudulenta $(3,53 / 5)$

Impedir telemóveis ligados na sala onde se realizam exames $(3,48 / 5)$

Utilização de mecanismos de vigilância e de deteção eletrónica de fraude (3,39/5)

\section{Inibidores menos importantes}

Frequência de disciplinas sobre Ética $(2,21 / 5)$

Sessões de esclarecimento promovidas pela escola sobre a boa conduta académica $(2,25 / 5)$

Divulgação no ambiente escolar do nome dos alunos que praticaram fraudes $(2,51 / 5)$

\section{Categorias de inibidores}

Fator 1 - estratégias de informação

Fator 2 - estratégias de dissuasão

Fator 3 - estratégias de apoio pedagógico

\section{Análise}

Os principais inibidores da fraude entre os alunos de medicina estão relacionados com a penalização e dissuasão da fraude, destacando-se o agravamento da pena e a prevenção durante o exame (proibição de usos de telemóvel) e fiscalização na avaliação de trabalhos (utilização de software de deteção de plágio). IPF explicado principalmente pelo fator 1 , o que sugere que estratégias de informação serão as mais relevantes para combater a predisposição para cometer fraude académica. 


\subsubsection{Enfermagem}

N.o de alunos: 638

FREQUÊNCIA

Perceção sobre a frequência de fraude

$51,7 \%$ com alguma frequência

$27,7 \%$ regularmente

Mulheres percecionam mais fraude do que os homens.

Alunos mais novos também.

\section{Fraudes mais frequentes}

Copiar numa prova escrita pelas respostas de um colega $(3,16 / 4)$

Deixar copiar respostas num exame $(3,07 / 4)$

Utilizar materiais não autorizados na realização de provas escritas $(3,03 / 4)$

\section{Fraudes menos frequentes}

Comprar trabalhos a outros colegas $(1,57 / 4)$

Comprar trabalhos académicos fora da escola $(1,59 / 4)$

Apresentar trabalhos práticos com dados inventados $(1,83 / 4)$

\section{GRAVIDADE}

\section{Fraudes mais graves}

Comprar trabalho a colega $(8,47 / 10)$

Vender aos colegas trabalhos realizados por si próprio $(7,60 / 10)$

Inventar dados num trabalho escrito $(7,44 / 10)$

\section{Fraudes menos graves}

Apresentar o mesmo trabalho em diferentes disciplinas $(4,44 / 10)$

Permitir que um colega partilhe a autoria formal de um trabalho sem ter participado nele $(4,67 / 10)$

Fornecer respostas a um colega num exame $(5,43 / 10)$

\section{Categorias de fraude (segundo gravidade)}

Fator 1 - fraude individual (baseada na responsabilidade pessoal)

Fator 2 - fraude transacional (baseada em transação económica ou afetiva)

Fator 3 - fraude grupal (baseada na responsabilidade coletiva)

\section{IPF ENFERMAGEM $=4,10 / 10$}

IPF maior nos alunos:

- homens

- cujo percurso pré-universitário foi maioritariamente feito em escolas privadas

- que já reprovaram

- que reconhecem maior incidência de fraude no seu curso

\section{IPD ENFERMAGEM $=0,53 / 10$}

IPD maior nos alunos:

- que já leram o código disciplinar da instituição 


\section{MOTIVOS}

\section{Motivos mais importantes}

Carga de trabalho académico $(3,9 / 5)$

Assegurar o sucesso a uma disciplina à qual já se reprovou $(3,83 / 5)$

Insegurança sobre a capacidade de alcançar o sucesso de outra forma $(3,35 / 5)$

Motivos menos importantes

Falta de debate sobre o assunto nas aulas com os professores $(2,57 / 5)$

Competência pedagógica insuficiente dos professores $(2,58 / 5)$

\section{Categorias de motivos}

Fator 1 - política e cultura de fraude (nível institucional)

Fator 2 - pressão para o êxito (nível individual)

Fator 3 - práticas pedagógicas (nível curricular)

Análise

A relação do aluno com o curso e com as disciplinas parece prevalecer, como motivador da fraude, sobre motivos contextuais ou culturais exógenos a essa relação individual. Os resultados também mostram que os alunos tendencialmente menos propensos a cometer fraude tendem a valorizar mais os motivos institucionais e culturais como fatores facilitadores da fraude (fator 1$)(-9,4 \%)$. Isto pode significar que, nos cursos de enfermagem, os alunos potencialmente menos transgressores tendem a atribuir à instituição a responsabilidade pelas práticas de fraude cometidas pelos alunos, porventura por falhas na sua prevenção ou fiscalização.

\section{INIBIDORES}

\section{Inibidores mais importantes}

Agravamento das penas para conduta académica fraudulenta $(3,4 / 5)$

Utilização de mecanismos de vigilância e de deteção eletrónica de fraude $(3,23 / 4)$

Existência de uma relação de proximidade entre professores e alunos $(3,22 / 5)$

Inibidores menos importantes

Existência de provas orais obrigatórias (2,35/5)

Divulgação no ambiente escolar do nome dos alunos que praticaram fraudes $(2,38 / 5)$

Frequência de disciplinas sobre Ética $(2,43 / 5)$

\section{Categorias de inibidores}

Fator 1 - estratégias de dissuasão

Fator 2 - estratégias de informação

Fator 3 - estratégias de apoio pedagógico

\section{Análise}

Apesar do caráter preventivo do agravamento das penas dos mecanismos de controlo do comportamento, os resultados parecem sugerir que a relação de proximidade entre aluno e instituição pode efetivamente desincentivar a fraude. IPF explicado principalmente pelo fator 2 , sugerindo que os alunos mais transgressores tendem a sentir-se menos vulneráveis às políticas institucionais de formação e educação para um comportamento honesto. Este resultado parece revelar um certo descrédito e ineficácia das políticas institucionais de combate à fraude. 


\subsubsection{Educação}

N.o de alunos: 336

\section{FREQUÊNCIA}

Perceção sobre a frequência de fraude

$56,3 \%$ com alguma frequência

$20,5 \%$ regularmente

Alunos mais velhos percecionam mais fraude do que os homens.

Fraudes mais frequentes

Utilizar materiais não autorizados na realização de provas escritas $(3,08 / 4)$

Copiar numa prova escrita pelas respostas de um colega $(3,07 / 4)$

Deixar copiar respostas num exame $(2,89 / 4)$

\section{Fraudes menos frequentes}

Comprar trabalhos a outros colegas $(1,49 / 4)$

Comprar trabalhos académicos fora da escola $(1,5 / 4)$

Apresentar trabalhos práticos com dados inventados $(1,76 / 4)$

\section{GRAVIDADE}

\section{Fraudes mais graves}

Comprar trabalho a colega $(8,81 / 10)$

Vender aos colegas trabalhos realizados por si próprio $(8,03 / 10)$

Inventar dados num trabalho escrito $(7,22 / 10)$

Copiar trabalho da Internet $(7,21 / 10)$

\section{Fraudes menos graves}

Apresentar o mesmo trabalho em diferentes disciplinas $(4,72 / 10)$

Permitir que um colega partilhe a autoria formal de um trabalho sem ter participado nele $(5,2 / 10)$

Fornecer respostas a um colega num exame $(5,68 / 10)$

\section{Categorias de fraude (segundo gravidade)}

Fator 1 - fraude individual (baseada na responsabilidade pessoal)

Fator 2 - fraude transacional (baseada em transação económica ou afetiva)

Fator 3 - fraude grupal (baseada na responsabilidade coletiva)

IPF EDUCAÇÃO = 3,66/10

IPF maior nos alunos:

- que já reprovaram

- com média mais baixa

- que reconhecem maior incidência de fraude no seu curso 


\section{MOTIVOS}

\section{Motivos mais importantes}

Carga de trabalho académico $(3,86 / 5)$

Assegurar o sucesso a uma disciplina à qual já se reprovou $(3,79 / 5)$

Insegurança sobre a capacidade de alcançar o sucesso de outra forma $(3,29 / 5)$

\section{Motivos menos importantes}

Pressão competitiva entre os colegas $(2,79 / 5)$

Competência pedagógica insuficiente dos professores $(2,8 / 5)$

\section{Categorias de motivos}

Fator 1 - práticas pedagógicas (nível curricular)

Fator 2-política e cultura de fraude (nível institucional)

Fator 3 - pressão para o êxito (nível individual)

\section{Análise}

Os motivos mais relevantes dizem respeito aos obstáculos para alcançar êxito de outra forma. Curiosamente, a passividade dos professores e o hábito da conduta fraudulenta parecem também ser reconhecidos como motivadores da fraude entre estes alunos, sugerindo a eventual existência de uma cultura académica tolerante à fraude. A relação do aluno com o curso e com as disciplinas parece prevalecer, como motivador da fraude, sobre motivos contextuais ou culturais exógenos a essa relação individual. Os resultados também mostram que os alunos tendencialmente menos propensos a cometer fraude tendem a identificar as práticas pedagógicas como determinantes mais relevantes da fraude (fator 1) (15,6\%). Os alunos mais propensos a denunciar a fraude identificam as políticas institucionais e a cultura de fraude como motivos mais relevantes que a determinam (fator 2) (16,1\%). Isto pode significar que, nos cursos de formação de professores, é porventura necessário modificar as práticas pedagógicas ao nível de cada disciplina para combater a fraude e é necessário um ambiente institucional favorável para haver denúncia.

\section{INIBIDORES}

\section{Inibidores mais importantes}

Agravamento das penas para conduta académica fraudulenta $(3,52 / 5)$

Envolvimento dos estudantes na divulgação de boas práticas académicas $(3,36 / 4)$

Existência de uma relação de proximidade entre professores e alunos $(3,33 / 5)$

\section{Inibidores menos importantes}

Divulgação no ambiente escolar do nome dos alunos que praticaram fraudes $(2,38 / 5)$

Existência de provas orais obrigatórias $(2,49 / 5)$

Frequência de disciplinas sobre Ética $(2,82 / 5)$

\section{Categorias de inibidores}

Fator 1 - estratégias de informação

Fator 2 - estratégias de apoio pedagógico

Fator 3 - estratégias de dissuasão

Fator 4 - estratégias de comprometimento

\section{Análise}

Apesar do caráter preventivo do agravamento das penas, os resultados parecem sugerir que a relação de proximidade entre aluno e instituição pode efetivamente desincentivar a fraude, revelando a natural sensibilidade dos alunos destes cursos ao efeito de práticas pedagógicas de proximidade. IPF explicado pelos fatores 1 e 3, sugerindo que os alunos mais transgressores tendem a sentir-se menos vulneráveis às políticas institucionais de formação, educação e punição no contexto da fraude académica. Este resultado parece revelar um certo descrédito e ineficácia das políticas institucionais de combate à fraude. 


\subsubsection{Direito}

N.o de alunos: 281

\section{FREQUÊNCIA}

Perceção sobre a frequência de fraude

$44 \%$ com alguma frequência

$20,6 \%$ regularmente

Mulheres percecionam mais fraude do que os homens.

Alunos mais novos também.

\section{Fraudes mais frequentes}

Utilizar materiais não autorizados na realização de provas escritas $(2,85 / 4)$

Copiar numa prova escrita pelas respostas de um colega $(2,75 / 4)$

Deixar copiar respostas num exame $(2,6 / 4)$

\section{Fraudes menos frequentes}

Comprar trabalhos a outros colegas $(1,7 / 4)$

Comprar trabalhos académicos fora da escola $(1,73 / 4)$

Apresentar trabalhos práticos com dados inventados $(1,76 / 4)$

Apresentar o mesmo trabalho em várias disciplinas $(1,77 / 4)$

\section{GRAVIDADE}

\section{Fraudes mais graves}

Comprar trabalho a colega $(8,48 / 10)$

Consultar materiais não autorizados numa prova escrita $(7,93 / 10)$

Vender aos colegas trabalhos realizados por si próprio $(7,67 / 10)$

\section{Fraudes menos graves}

Permitir que um colega partilhe a autoria formal de um trabalho sem ter participado nele $(4,88 / 10)$

Apresentar o mesmo trabalho em diferentes disciplinas $(5,11 / 10)$

Emprestar a colegas trabalho realizado por si próprio para que estes apresentem como seu $(6,15 / 10)$

Categorias de fraude (segundo gravidade)

Fator 1 - fraude não transacional

Fator 2 - fraude transacional

IPF DIREITO $=3,12 / 10$

IPF maior nos alunos:

- mais novos

IPD DIREITO = 0,95/10

IPD maior nos alunos:

- nos alunos cujo curso que frequentam foi a sua primeira escolha

- nos alunos que já reprovaram 


\section{MOTIVOS}

\section{Motivos mais importantes}

Assegurar o sucesso a uma disciplina à qual já se reprovou $(3,71 / 5)$

Carga de trabalho académico $(3,35 / 5)$

Insegurança sobre a capacidade de alcançar o sucesso de outra forma $(3,24 / 5)$

\section{Motivos menos importantes}

Competência pedagógica insuficiente dos professores $(2,45 / 5)$

Falta de debate sobre o assunto nas aulas com os professores $(2,5 / 5)$

Passividade dos professores perante situações de fraude $(2,62 / 5)$

\section{Categorias de motivos}

Fator 1 - práticas pedagógicas (nível curricular)

Fator 2 - cultura de fraude (nível institucional)

Fator 3 - insegurança (nível individual)

Fator 4 - ignorância (nível individual)

\section{Análise}

Os resultados sugerem que não há, entre os alunos de Direito, um desconhecimento sobre o que é a boa conduta académica que justifique que seja cometida fraude académica. Os motivos mais relevantes dizem respeito aos obstáculos para alcançar êxito de outra forma, quer sejam as características do curso ou a insegurança do aluno, existindo uma certa cultura de fraude que favorece a transgressão. Os professores são aparentemente ilibados de culpa. Por outro lado, quanto mais predisposto a cometer fraude, mais importância atribui à falta de confiança em si mesmo como motivador do ato transgressor. Isto pode significar que, nos cursos de direito, poderá existir um contexto de carga porventura excessiva de trabalho que favorece a fraude por parte dos alunos.

\section{INIBIDORES}

\section{Inibidores mais importantes}

Agravamento das penas para conduta académica fraudulenta $(3,57 / 5)$

Impedir telemóveis ligados na sala onde se realizam exames $(3,43 / 5)$

Utilização de mecanismos de vigilância e de deteção eletrónica de fraude $(3,22 / 4)$

Existência de uma relação de proximidade entre professores e alunos $(3,21 / 5)$

\section{Inibidores menos importantes}

Frequência de disciplinas sobre Ética $(2,5 / 5)$

Divulgação no ambiente escolar do nome dos alunos que praticaram fraudes $(2,51 / 5)$

Existência de provas orais obrigatórias (2,59/5)

\section{Categorias de inibidores}

Fator 1 - estratégias de informação

Fator 2 - estratégias de dissuasão

Fator 3 - estratégias de compromisso institucional

\section{Análise}

Apesar do caráter preventivo do agravamento das penas e dos mecanismos de controlo do comportamento, os resultados parecem sugerir que a relação de proximidade entre aluno e instituição pode efetivamente desincentivar a fraude. Curiosamente, a divulgação pública do nome dos transgressores e a frequência de aulas sobre Ética não parecem medidas eficazes de combate à fraude entre os alunos de direito. IPF explicado principalmente pelos fatores 1 e 2, sugerindo que, nos cursos de direito, os alunos mais transgressores tendem a sentir-se menos influenciados pelas políticas institucionais de formação anti-fraude e pelos mecanismos preventivos e punitivos da fraude. Este resultado parece revelar um certo descrédito e ineficácia das políticas institucionais de combate à fraude. 


\title{
4.2.7. Ciências Sociais e Humanas
}

\author{
N.․o de alunos: 542 \\ FREQUÊNCIA \\ Perceção sobre a frequência de fraude \\ $48 \%$ com alguma frequência \\ $27,9 \%$ regularmente \\ Alunos mais velhos, com mais inscrições e com média mais alta percecionam mais fraude. \\ Fraudes mais frequentes \\ Utilizar materiais não autorizados na realização de provas escritas $(2,97 / 4)$ \\ Copiar numa prova escrita pelas respostas de um colega $(2,94 / 4)$ \\ Deixar copiar respostas num exame $(2,82 / 4)$

\section{Fraudes menos frequentes} \\ Comprar trabalhos a outros colegas $(1,55 / 4)$ \\ Comprar trabalhos académicos fora da escola $(1,61 / 4)$ \\ Apresentar o mesmo trabalho em várias disciplinas $(1,92 / 4)$ \\ Apresentar trabalhos práticos com dados inventados $(1,92 / 4)$
}

\section{GRAVIDADE}

\section{Fraudes mais graves}

Comprar trabalho a colega $(8,63 / 10)$

Vender aos colegas trabalhos realizados por si próprio $(7,69 / 10)$

Copiar trabalho da Internet $(7,58 / 10)$

\section{Fraudes menos graves}

Permitir que um colega partilhe a autoria formal de um trabalho sem ter participado nele $(5,01 / 10)$

Apresentar o mesmo trabalho em diferentes disciplinas $(5,02 / 10)$

Fornecer respostas a um colega num exame $(5,84 / 10)$

Categorias de fraude (segundo gravidade)

Fator 1 - fraude não transacional

Fator 2 - fraude transacional (baseada em transação económica ou afetiva)

\section{IPF C. SOCIAIS E HUMANAS $=3,5 / 10$}

IPF maior nos alunos:

- mais novos

- cujo percurso não foi a primeira escolha

- com menor média

- que reconhecem maior incidência de fraude no seu curso

IPD C. SOCIAIS E HUMANAS $=0,67 / 10$ 


\section{MOTIVOS}

\section{Motivos mais importantes}

Assegurar o sucesso a uma disciplina à qual já se reprovou $(3,74 / 5)$

Carga de trabalho académico $(3,65 / 5)$

Insegurança sobre a capacidade de alcançar o sucesso de outra forma $(3,32 / 5)$

\section{Motivos menos importantes}

Competência pedagógica insuficiente dos professores $(2,6 / 5)$

Falta de debate sobre o assunto nas aulas com os professores $(2,67 / 5)$

\section{Categorias de motivos}

Fator 1 - cultura de fraude (nível institucional)

Fator 2 - práticas pedagógicas (nível curricular)

Fator 3 - insegurança (nível individual)

Fator 4-ignorância (nível individual)

\section{Análise}

A relação do aluno com o curso e com as disciplinas parece prevalecer, como motivador da fraude, sobre motivos contextuais ou culturais exógenos a essa relação individual. Os resultados também parecem sugerir uma certa legitimação da fraude justificada por uma exigência excessiva de trabalho. Os alunos mais propensos a cometerem fraude tendem a valorizar o ambiente cultural e a sua própria insegurança como motivadores do comportamento desviante (fatores 1 e 3) (17,6\% e 7,7\%, respetivamente). Isto pode significar que, nas áreas científicas relacionadas com o comportamento humano, a prática de fraude académica é essencialmente motivada por uma pressão para conformidade e para o cumprimento de metas socialmente desejáveis.

\section{INIBIDORES}

\section{Inibidores mais importantes}

Agravamento das penas para conduta académica fraudulenta $(3,4 / 5)$

Existência de uma relação de proximidade entre professores e alunos $(3,26 / 5)$

Impedir telemóveis ligados na sala onde se realizam exames $(3,19 / 4)$

\section{Inibidores menos importantes}

Existência de provas orais obrigatórias $(2,41 / 5)$

Frequência de disciplinas sobre Ética $(2,42 / 5)$

Divulgação no ambiente escolar do nome dos alunos que praticaram fraudes $(2,43 / 5)$

\section{Categorias de inibidores}

Fator 1 - estratégias de dissuasão

Fator 2 - estratégias de informação

Fator 3 - estratégias de apoio pedagógico

\section{Análise}

Apesar do caráter punitivo do agravamento das penas e dos mecanismos de controlo do comportamento, os resultados parecem sugerir que a relação de proximidade entre aluno e instituição pode efetivamente desincentivar a fraude. IPF explicado principalmente pelos fatores 1 e 2 , sugerindo que, nestas áreas científicas, os alunos mais transgressores tendem a sentir-se menos vulneráveis às políticas institucionais de prevenção e educação para um comportamento honesto. Este resultado parece revelar um certo descrédito e ineficácia das políticas institucionais de combate à fraude. 


\subsubsection{Artes}

N.․o de alunos: 499

\section{FREQUÊNCIA}

Perceção sobre a frequência de fraude

$45,2 \%$ com alguma frequência

$21,7 \%$ regularmente

Mulheres percecionam mais fraude do que os homens.

Alunos que escolheram o curso em primeira opção também.

Alunos mais velhos e com mais inscrições também.

\section{Fraudes mais frequentes}

Utilizar materiais não autorizados na realização de provas escritas $(3,02 / 4)$

Copiar numa prova escrita pelas respostas de um colega $(2,93 / 4)$

Copiar trabalhos da Internet $(2,83 / 4)$

Assinar um trabalho de grupo sem ter colaborado na realização do mesmo $(2,82 / 4)$

\section{Fraudes menos frequentes}

Comprar trabalhos a outros colegas $(1,64 / 4)$

Comprar trabalhos académicos fora da escola $(1,67 / 4)$

\section{GRAVIDADE}

\section{Fraudes mais graves}

Comprar trabalho a colega $(8,48 / 10)$

Vender aos colegas trabalhos realizados por si próprio $(7,37 / 10)$

Plágio autorizado do trabalho de um colega $(7,08 / 10)$

Fraudes menos graves

Apresentar o mesmo trabalho em diferentes disciplinas $(4,20 / 10)$

Permitir que um colega partilhe a autoria formal de um trabalho sem ter participado nele $(4,51 / 10)$

Fornecer respostas a um colega num exame $(5,51 / 10)$

\section{Categorias de fraude (segundo gravidade)}

Fator 1 - fraude não transacional

Fator 2 - fraude transacional (baseada em transação económica ou afetiva)

IPF ARTES $=4,19 / 10$

IPF maior nos alunos:

- homens

- cujo curso não foi primeira opção

- que já reprovaram

- com menor média

- que reconhecem maior incidência de fraude no seu curso

IPD ARTES $=0,56 / 10$

IPD maior nos alunos:

- com maior média 


\section{MOTIVOS}

\section{Motivos mais importantes}

Carga de trabalho académico $(3,86 / 5)$

Assegurar o sucesso a uma disciplina à qual já se reprovou $(3,72 / 5)$

Hábito de uma conduta fraudulenta desde o ensino secundário $(3,29 / 5$

\section{Motivos menos importantes}

Pressão competitiva entre os colegas $(2,51 / 5)$

Falta de conhecimento sobre qual deve ser a boa conduta académica $(2,72 / 5)$

\section{Categorias de motivos}

Fator 1 - política e cultura de fraude (nível institucional)

Fator 2 -práticas pedagógicas (nível da disciplina)

Fator 3 - pressão para o êxito (nível individual)

\section{Análise}

A predisposição para a fraude pode ser mais estimulada por meio da relação do aluno com a disciplina do que por motivos contextuais ou culturais exógenos a essa relação individual; responsabilização prioritária dos níveis de exigência pedagógica de cada curso como fator que estimula a fraude entre os alunos. IPF maior com fator 2 , confirmando análise de que os motivos mais críticos se situam ao nível da relação do aluno com o curso/disciplina.

\section{INIBIDORES}

\section{Inibidores mais importantes}

Existência de uma relação de proximidade entre professores e alunos $(3,35 / 5)$

Agravamento das penas para conduta académica fraudulenta $(3,33 / 5)$

Impedir telemóveis ligados na sala onde se realizam exames $(3,12 / 5)$

\section{Inibidores menos importantes}

Divulgação no ambiente escolar do nome dos alunos que praticaram fraudes $(2,35 / 5)$

Frequência de disciplinas sobre Ética $(2,39 / 5)$

Existência de provas orais obrigatórias $(2,48 / 5)$

\section{Categorias de inibidores}

Fator 1 - estratégias de dissuasão

Fator 2 - estratégias de informação

Fator 3 - estratégias de apoio pedagógico

\section{Análise}

Apesar do caráter punitivo do agravamento das penas e do impedimento de ter telemóveis ligados durante os exames, os resultados parecem sugerir que a relação de proximidade entre aluno e instituição pode efetivamente desincentivar a fraude. IPF explicado principalmente pelo fator 1, o que sugere que estratégias de dissuasão serão as mais relevantes para combater a predisposição para cometer fraude académica. 


\title{
4.3. Resumo dos Resultados dos Professores
}

\author{
N.. - de Docentes: 2727 \\ FREQUÊNCIA \\ Perceção sobre a frequência de fraude \\ $55,1 \%$ com alguma frequência \\ $10,9 \%$ regularmente \\ Perceção sobre a frequência da fraude é maior em docentes: \\ . mulheres \\ . do setor público \\ . do ensino universitário \\ . com mais anos de experiência como docente \\ . com maior qualificação (mestrado e doutoramento) \\ . que dizem não existir código de boas práticas na sua instituição
}

Fraudes consideradas mais frequentes

\section{COPIAR EM EXAME}

$64,4 \%$ dos docentes portugueses considera que os alunos utilizam materiais não autorizados na realização de provas escritas com alguma frequência $(45 \%)$ ou regularmente $(19,4 \%)$.

$65,3 \%$ dos docentes portugueses considera que os alunos copiam numa prova escrita pelas respostas de um colega com alguma frequência (51\%) ou regularmente (14,3\%).

\section{COPIAR EM TRABALHO}

$85 \%$ dos docentes portugueses considera que se os alunos copiam partes de trabalhos de outros autores sem os citar com alguma frequência $(39,4 \%)$ ou regularmente $(45,6 \%)$.

$78,4 \%$ dos docentes portugueses considera que os alunos copiam trabalhos da Internet com alguma frequência $(43,4 \%)$ ou regularmente $(35 \%)$.

$66,3 \%$ dos docentes portugueses considera que os alunos copiam trabalhos de outros colegas com alguma frequência $(44,1 \%)$ ou regularmente $(22,2 \%)$.

\section{Resumo}

. Docentes consideram que são mais frequentes fraudes relacionadas com a realização de trabalhos do que com a realização de provas escritas.

. Docentes consideram que em geral as fraudes ocorrem com alguma frequência, em trabalhos e em exame, mas ignoram se se compram trabalhos ou se se inventam dados.

. Docentes reconhecem quase não existir denúncia entre os alunos.

\section{GRAVIDADE}

\section{Fraudes mais graves}

Comprar trabalho a colega $(9,47 / 10)$

Copiar trabalho de um colega $(9,31 / 10)$

Inventar dados num trabalho escrito $(9,25 / 10)$

\section{Fraudes menos graves}

Permitir que um colega partilhe a autoria formal de um trabalho sem ter participado nele $(6,42 / 10)$

Apresentar o mesmo trabalho em diferentes disciplinas $(6,89 / 10)$

\section{Resumo}

. Os docentes atribuem gravidade elevada à generalidade das fraudes académicas, no entanto, consideram em geral mais graves aquelas que são cometidas em trabalhos do que em exame escrito (por exemplo, vender ou emprestar trabalho é mais grave do que fornecer respostas num exame). 
ISF DOCENTES $=8,37 / 10$

ISF (Indicador de Sensibilidade à Fraude) maior nos docentes:

- mulheres

- que sabem se existe ou não existe código de boas práticas na sua instituição

- que, reconhecendo existir regulamento disciplinar, já o leram

- com mestrado ou doutoramento

- mais velhos

- com mais anos de experiência académica

IIT DOCENTES $=8,18 / 10$

IIF (Indicador de Intolerância à Fraude) maior nos docentes:

- mulheres

- do setor privado

- do ensino politécnico

- que reconhecem existir regulamento disciplinar na sua instituição

- que, reconhecendo existir regulamento disciplinar, já o leram

\section{ISA DOCENTES $=7 / 10$}

Satisfação com o Ensino

ISE DOCENTES: 7,93 (0-10)

Satisfação com a Instituição

ISI DOCENTES: 7,34 (0-10)

Satisfação com a Política da instituição

ISP DOCENTES: 5,74 (0-10)

ISA (Indicador de Satisfação Académica) maior nos docentes:

- mulheres

- do setor privado

- do ensino politécnico

- que reconhecem existir regulamento disciplinar na sua instituição

- que consideram existir menos fraude na sua instituição

- mais novos

- com menos experiência académica

\section{IIF, IIT e ISA}

Sensibilidade e Intolerância á Fraude (correlação 0,366)

Satisfação Académica e Intolerância à Fraude (correlação 0,229)

Satisfação Académica e Sensibilidade à Fraude (correlação 0,089) 


\section{MOTIVOS}

\section{Motivos mais importantes}

Hábito de uma conduta fraudulenta desde o ensino secundário $(3,36 / 5)$

Assegurar o sucesso a uma disciplina à qual já se reprovo $(3,25 / 5)$

Perceção de que a pena, no caso de ser descoberta a fraude, é pouco significativa $(3,19 / 5)$

\section{Motivos menos importantes}

Competência pedagógica insuficiente dos professores $(2,25 / 5)$

Pressão competitiva entre os colegas $(2,27 / 5)$

\section{Categorias de motivos}

Fator 1 - práticas pedagógicas (nível curricular)

Fator 2 - cultura de fraude (nível institucional)

Fator 3 - insegurança (nível individual/relacional)

Fator 4 - ignorância (nível individual)

Resumo

- Os resultados sugerem que os doentes tendem a atribuir as causas da prática fraudulenta ao próprio aluno que a comete, por insegurança ou por hábito, desvalorizando a dimensão pedagógica e curricular associada com a carga de trabalho letivo, as modalidades de avaliação ou a competência dos professores.

. Os docentes tendem a justificar a prática fraudulenta com a insegurança do aluno, a cultura de fraude e a leveza aparente da punição.

. Os motivos relacionados com a dimensão pedagógica e curricular são considerados menos relevantes, embora com uma exceção interessante: a passividade dos professores perante situações de fraude é reconhecida como um motivo importante $(3,06 / 5)$.

. Os docentes mais predispostos a combater a fraude tendem a responsabilizar os próprios alunos pela transgressão.

. Os docentes menos satisfeitos com a carreira e com a instituição, tendem também a responsabilizar o plano institucional pela prática de fraude entre alunos.

\section{INIBIDORES DA FRAUDE}

\section{Inibidores mais importantes}

Agravamento das penas para conduta académica fraudulenta $(3,43 / 5)$

Envolvimento dos estudantes na divulgação de boas práticas académicas (3,32/5)

Divulgação de um Código de Conduta da escola $(3,22 / 5)$

\section{Inibidores menos importantes}

Garantia de anonimato na denúncia de comportamentos fraudulentos dos colegas estudantes $(2,42 / 5)$

Divulgação no ambiente escolar do nome dos alunos que praticaram fraudes $(2,45 / 5)$

Frequência de disciplinas sobre Ética $(2,66)$

$.89,5 \%$ dos docentes considera que o agravamento das penas é um inibidor importante $(34,4 \%)$ ou mesmo muito importante (55\%).

.76,5\% dos docentes considera que impedir telemóveis ligados na sala onde se realizam exames é um inibidor importante $(37,5 \%)$ ou mesmo muito importante $(39 \%)$.

. 43,2\% dos docente considera nada importante $(9,8 \%)$ ou pouco importante $(33,4 \%)$ a frequência de disciplinas sobre Ética como fator inibidor da fraude.

. 34,2\% dos docente considera nada importante $(10,2 \%)$ ou pouco importante $(24 \%)$ a existência de uma relação de proximidade com os professores como fator inibidor da fraude $(41,4 \%$ considera, neste contexto, essa relação importante).

\section{Categorias de inibidores}

Fator 1 - estratégias de informação

Fator 2 - estratégias de dissuasão

Fator 3 - estratégias de apoio pedagógico 
Resumo

. Existência de uma relação de proximidade com os professores parece ser um inibidor da fraude medianamente valorizado pelos docentes, privilegiando a formação e os mecanismos dissuasores como meios prioritários de combate à fraude.

\section{INIBIDORES DA DENÚNCIA}

Inibidores mais importantes

Perceção de que a denúncia não produzirá efeitos punitivos $(2,67 / 4)$

Burocracia processual $(2,66 / 4)$

Inibidores menos importantes

Eventual prejuízo da reputação do docente $(1,92 / 4)$

Severidade excessiva da eventual punição $(2,09 / 4)$

\section{Categorias de inibidores da denúncia}

Fator 1 - inibidores institucionais

Fator 2 - inibidores pessoais

\section{Resumo}

. Os resultados parecem agrupar dois tipos de inibidores da denúncia por parte dos docentes. Os mais relevantes, na sua opinião, estão relacionados com um certo grau de desconfiança institucional, de descrença nos processos administrativos e na capacidade ou disponibilidade punitiva da instituição. Os inibidores menos relevantes estão relacionados com as dimensões pessoal e relacional, ou seja, o impacto da punição no aluno e do processo delatório na relação dos alunos com o professor tendem a ser desvalorizados como motivos para evitar a denúncia da fraude.

\section{RESPOSTA À FRAUDE}

Respostas mais comuns:

Copiar por um colega em exame escrito: Adverte o aluno (56,7\%)

Utilizar materiais não autorizados durante a realização de exame escrito: Penaliza a avaliação (62,3\%)

Apresentar trabalho plagiado: Penaliza a avaliação $\mathbf{( 7 8 , 7 \% )}$

Assumir co-autoria de trabalho no qual não participou: Penaliza a avaliação $(\mathbf{7 6 , 6 \% )}$

Apresentar o mesmo trabalho que já havia apresentado em outra disciplina: Penaliza a avaliação (66,6\%)

Apresentar trabalho com dados falsos: Penaliza a avaliação (72\%)

. A principal resposta dos docentes perante situação de fraude é a penalização da avaliação.

. A advertência do aluno é também comum, embora, no caso da submissão de um trabalho plagiado haja mais docentes a informar o coordenador de curso do que advertir o aluno. 
(Página deixada propositadamente em branco) 


\section{A P Í T U L O V \\ CONCLUSÕ ESPRINCIPAIS}

O ensino superior tem uma função estruturante na sociedade, quer por via da produção e reprodução de conhecimento, quer por via da sua contribuição para a formação de cidadãos conscientes e responsáveis perante os seus direitos e os seus deveres. Por isso a fraude académica, nesse contexto, é um fenómeno corrosivo que pode comprometer alicerces fundamentais da vida social, como sejam a confiança recíproca, a competência qualificada e a transparência relacional. Ela pode ser cometida por alunos e por docentes no âmbito das relações de ensino-aprendizagem ou em atividades de investigação e transferência de conhecimento. Dada a relevância que pode ter para entender a futura ética profissional dos atuais alunos e para compreender o sistema de pensamento moral de uma ampla camada de jovens qualificados portugueses, optou-se por estudar apenas a fraude cometida por alunos no âmbito da sua relação com os docentes e com a avaliação do seu desempenho no ensino superior. Assim, este livro analisou as perceções e opiniões de alunos e professores em Portugal sobre este fenómeno aparentemente transversal a todas as áreas disciplinares e todos os contextos académicos.

Eis uma síntese de alguns dos principais resultados e conclusões que foi possível alcançar:

- A amostra estudada de alunos portugueses do ensino superior foi constituída por 7.292 alunos de 182 cursos de 101 
instituições de ensino superior portuguesas, incluindo os subsistemas de ensino universitário e politécnico, público e privado. A amostra de docentes foi constituída por 2.727 docentes portugueses dos mesmos quatro subsistemas de ensino superior em Portugal.

- Segundo os alunos, as fraudes mais frequentes ocorrem na realização de provas escritas, enquanto os docentes consideram mais frequentes as fraudes em trabalhos. Embora também justificada por razões metodológicas, a tendência atual para a substituição total ou parcial das provas escritas pela realização de trabalhos individuais ou em grupo pode ser uma resposta à incidência acentuada de fraude cometida durante os exames. Talvez por isso os docentes também estejam mais atentos às fraudes cometidas nesses contextos de avaliação contínua.

- A denúncia de fraude pelos alunos é quase inexistente, o que sugere a existência de uma cultura de tolerância e de encobrimento da fraude entre os alunos, porventura baseada num sistema de cumplicidades e de reciprocidades que a legitima e alimenta. No enanto, embora sempre muito baixa, a predisposição para denunciarem a fraude é maior em alunos com maior média atual no seu curso, com menos inscrições no ensino superior e que já leram o regulamento disciplinar da escola. Quando comparadas as diferentes áreas científicas, os alunos de Direito e da área da Educação apresentam predisposições para a denúncia da fraude mais elevadas e os alunos das Engenharias, Medicina e Economia e Gestão apresentam as predisposições mais baixas.

- Segundo os alunos, é mais grave apropriar-se de trabalho alheio do que facilitar a apropriação a outro, e é mais grave facilitar a apropriação do trabalho do que simulá-lo. Por outro lado, a disponibilidade dos alunos para facilitarem a fraude é 
mais alta do que a sua predisposição para a cometerem, o que sugere uma atitude de natural aversão ao risco e de grande tolerância à fraude, preferindo o envolvimento solidário na prática do que o protagonismo indesculpável da iniciativa.

- Os alunos distinguem a gravidade da fraude, não consoante o seu tipo - ativo ou passivo -, mas consoante a instância de avaliação em que é praticada: na realização de trabalho ou de exame escrito. É no entanto evidenciada no pensamento dos alunos uma terceira instância de gravidade, maior do que as demais, que se refere à fraude cometida com recurso a vantagens sociais e económicas que diferenciam os alunos entre si na medida em que só estão ao alcance de alguns.

- A predisposição para cometer fraude é maior em alunos homens, cujos pais têm maior grau de escolaridade e os agregados familiares rendimentos mais elevados, cujo percurso pré-universitário foi maioritariamente feito em escolas privadas, cujo curso que escolheram não foi a primeira opção, que têm menor média atual de curso, com mais inscrições no ensino superior e que não leram ou desconhecem a existência de regulamentos disciplinares. Quando comparadas as diferentes áreas científicas, os alunos das Engenharias e da Economia e Gestão registam uma predisposição para cometerem fraude acima da média, enquanto os alunos de Direito registam a predisposição mais baixa.

- Os motivos para cometer fraude podem ser organizados em quatro categorias: cultura de fraude (nível institucional), práticas pedagógicas (nível curricular), insegurança (nível individual); e ignorância (nível individual).

- Os motivos que os alunos consideram mais relevantes para explicar o comportamento fraudulento estão relacionados com a necessidade de assegurar o sucesso e a carga de trabalho académico. Os resultados sugerem que a fraude poderá 
ser uma resposta à pressão exercida mais pelos métodos de avaliação, do que pelo insuficiente desempenho técnico e didático dos professores, existindo porventura um contexto de carga excessiva de trabalho que favorece a fraude, assim como um descrédito generalizado na eficácia da intervenção institucional para combatê-la.

- Os docentes tendem a explicar a prática fraudulenta dos alunos com a sua insegurança, a cultura de fraude e a leveza aparente da punição, ou seja, tendem a atribuir as causas da fraude ao próprio aluno que a comete, por insegurança ou por hábito, desvalorizando a dimensão pedagógica e curricular associada com a carga de trabalho letivo, as modalidades de avaliação ou a competência dos professores.

- Quando comparadas as opiniões de alunos e docentes sobre os motivos da fraude, conclui-se que os alunos tendem a responsabilizar mais do que os docentes os aspetos pedagógicos relacionados com a exigência das formas de avaliação, enquanto os docentes consideram mais relevante do que os alunos a impunidade percecionada. Ou seja, os alunos tendem a culpabilizar os docentes e os docentes tendem a culpabilizar a instituição.

- Os inibidores da fraude podem ser organizados em três tipos de estratégias de combate à fraude: estratégias de dissuasão; estratégias de informação; e estratégias de apoio pedagógico.

- Além da previsível valorização do agravamento das penas como medida inibidora da fraude, os alunos destacam claramente a relação de proximidade entre alunos e professores como um elemento-chave para desincentivar a prática fraudulenta. Em relações pedagógicas de proximidade o compromisso moral entre aluno e professor é maior e a inibição da fraude mais eficaz, dado ser uma resposta ativa a um imperativo interior e não uma reação defensiva perante uma ameaça exterior. 
- Na opinião dos docentes, os inibidores mais eficazes no combate à fraude académica são o agravamento das penas para conduta académica fraudulenta, o envolvimento dos estudantes na divulgação de boas práticas académicas e a divulgação de um Código de Conduta da escola, privilegiando claramente uma política institucional mais afirmativa na punição e na informação.

- Quando comparadas as opiniões de alunos e docentes sobre os inibidores da fraude, constata-se que uma das maiores dissonâncias entre elas refere-se ao inibidor mais valorizado pelos alunos e que é, simultaneamente, um elemento essencial do processo educativo e relacional: a existência de uma relação de proximidade entre professores e alunos. Os docentes valorizam mais do que os alunos as soluções de formação e de informação, enquanto os alunos parecem reclamar uma relação mais personalizada com a instituição que os docentes não parecem reconhecer como prioritária.

- No caso da opinião dos docentes, parece existir uma valorização maior das fraudes cometidas em trabalhos do que cometidas em exame escrito, condenando especialmente a compra de trabalho, o plágio autorizado de trabalho e a invenção de dados num trabalho escrito. Em geral, os docentes condenam mais as práticas ativas do que as práticas passivas, especialmente em trabalhos de grupo, talvez por reconhecerem que, no âmbito da sua liberdade de decisão sobre como repartir internamente as tarefas, o grupo de trabalho assume solidariamente as consequências da injustiça provocada por uma nota coletiva.

- A sensibilidade à fraude, medida pela gravidade que lhe atribuem, é maior em docentes mulheres, que sabem se existe ou não existe código de boas práticas na sua instituição e com mais anos de experiência académica e científica. 
- A intolerância à fraude, medida pelo rigor do comportamento preventivo e de vigilância, é maior em docentes mulheres, do ensino politécnico, que reconhecem existir regulamento disciplinar e que já o leram.

- A principal reação dos docentes perante a deteção de situações de fraude cometidas por alunos é a penalização da avaliação, confirmando a sua predisposição para agir perante a fraude observada, mas restringindo a ação à esfera da relação bilateral entre docente e aluno, confirmada pelo facto de menos de um terço dos docentes transferir para a esfera institucional a resposta à fraude académica.

- Os docentes reconhecem como fatores que mais poderão inibi-los de denunciar a fraude a perceção de que a denúncia não produzirá efeitos punitivos ou a burocracia processual, sendo esta opinião um indicador de que haverá porventura um desincentivo institucional passivo à denúncia. Vários docentes também consideram que a baixa predisposição para denunciar a fraude pode ser explicada pela crença de que a denúncia pode ter efeitos contraproducentes ou pelo próprio desinteresse generalizado dos docentes nesse processo, mais pressionados para valorizarem a dimensão científica da sua carreira do que para envolverem-se em processos de conflito com alunos que poderão até penalizar a própria avaliação de desempenho docente.

Com base num amplo estudo sobre a opinião e a perceção de alunos e docentes do ensino superior em Portugal acerca da fraude académica cometida por alunos, procurou-se com este livro ampliar o debate e lançar pistas para uma reflexão fundamentada sobre o tema, as suas causas e os meios de combate mais eficazes. Trata-se de um fenómeno social complexo que não deve ser abordado a partir de uma única perspetiva e cujo significado será porventura 
melhor entendido à luz dos desacordos de perceção entre alunos e docentes do que à luz das suas convergências de opinião.

Embora os docentes privilegiem a formação e os mecanismos dissuasores como meios prioritários de combate à fraude, os alunos parecem alertar subliminarmente para os perigos de um distanciamento crescente nas relações pedagógicas e da despersonalização das relações académicas. A incompreensão dos motivos profundos que explicam a conduta transgressora dos alunos e dos fatores que podem combatê-la eficazmente é um indiscutível obstáculo ao êxito do processo de ensino-aprendizagem, cujo fracasso se reflete inevitavelmente em termos pessoais e sociais. O papel dos docentes e das instituições é central e decisivo neste combate. Ignorar o ponto de vista do aluno sobre estes aspetos é um erro que pode conduzir a políticas equivocadas, medidas inúteis e mal entendidos contraproducentes.

Este livro e o estudo que lhe deu origem constituem uma contribuição para evitar os indesejáveis efeitos da fraude, visando contribuir para um sistema de ensino mais justo e uma sociedade mais competente e com maiores e mais sustentáveis possibilidades de progresso material e moral. 
(Página deixada propositadamente em branco) 


\section{RE F E R Ê N C I A S B I B I O GRÁ F I CAS}

\section{Referências mencionadas no corpo do texto}

McCabe, D. (1999). Academic Dishonesty Among High School Students. Adolescence, 139(34), 681-687

Morris D., \& Kilian C. (2006). Do Accounting Students Cheat? A Study Examining Undergraduate Accounting Students' Honesty and Perceptions of Dishonest Behavior. Journal of Accounting, Ethics \& Public Policy, 3(5), 375-393

Rennie S., \& Rudland J. (2003). Differences in Medical Students' Attitudes to Academic Misconduct and Reported Behaviour Across Years - a Questionnaire Study. Journal of Medical Ethics, 2(29), 97-102

Teixeira, A., \& Rocha, M.F. (2010). Cheating by economics and business undergraduate students: An exploratory international assessment. High Education. 59, 663-701

\section{Outras referências sobre Fraude Académica}

Bazerman, C. (2010). Paying the rent: languaging particularity and novelty. Revista Brasileira de Linguística Aplicada, 2(10), 459-469.

Brandt, D. (2002). Copyright's (not so) little cousin, plagiarism. Computers in Libraries, 22(5), 39-42.

Bunn, D., Caudill, S. \& Gropper, D. (1992). Crime in a classroom: An economic analysis of undergraduate student cheating behavior. Journal of Economic Education. 23, 197-207.

Caballero, A. J. D. et al. (2010). Relación del fraude académico con situaciones personales que enfrentan los estudiantes en la Facultad de Odontología de la Universidad de Cartagena (Colombia). Revista Salud Uninorte, 26 (1): 85-97.

Callahan, D. (2004). The cheating culture: Why more Americans are doing wrong to get ahead. Florida, USA: Hartcourt Books.

Crittenden, V., Hanna, R., \& Peterson, R. (2009). The cheating culture: A global societal phenomenon. Business Horizons, 52(4), 337-346.

Gomes, L. L. Z. (2011). Internet; Instrumento de plágio ou instrumento de pesquisa? Revista Triângulo, 1(4), 1-10. 
Hrabak, M.; Vujaklija, A.; Vodopivec, I.; Hren, D.; Marusic, M \& Marusic, A. (2004). Academic misconduct among medical students in a postcommunist country. Medical Education. 38(3), 276-285

Jager, K., \& Brown, C. (2010). The tangled web: Investigating academics' views of plagiarism at the University of Cape Town. Studies in Higher Education, 35(5), 513-528

Lawson, R. (2004). Is classroom cheating related to business student's propensity to cheat in the "real world"? Journal of Business Ethics, 49, 189-199

Malgwi, C., \& Rakovski, C. (2009). Combating academic fraud: Are students reticent about uncovering the covert? Journal of Academic Ethics, 7, 207-221

Marsden, H., Carroll, M., \& Neill, J. (2005). Who cheats at university? A self-report study of dishonest academic behaviours in a sample of Australian university students. Australian Journal of Psychology, 57(1), 1-10

Mayhew, M., Seifert, T., \& Pascarella, E. (2010). A multi-institutional assessment of moral reasoning development among first-year students. Review of Higher Education: Journal of the Association for the Study of Higher Education, 33(3), 357-390

McCabe, D. (2009). Academic dishonesty in nursing schools: An empirical investigation. Journal of Nursing Education, 48(11), 614-623

McCabe, D., Butterfield, K., \& Trevino, L. (2003). Faculty and academic integrity: The influence of current honor codes and past honor code experiences. Research in Higher Education, 44(3), 367-385

McCabe, D., Butterfield, K., \& Trevino, L. (2006). Academic dishonesty in graduate business programs: Prevalence, causes, and proposed action. Academy of Management Learning \& Education, 5(3), 294-305

McCabe, D., Trevino, L., \& Butterfield, K. (2001). Cheating in academia institutions: A decade of research. Ethics \& Behavior, 11(3), 219-232

McCabe, D., Trevino, L., \& Butterfield, K. (2002). Honor codes and other contextual influences on academic integrity: A replication and extension to modified honor code settings. Research in Higher Education, 43(3), 357-378

Mirshekary, S., \& Lawrence, A. (2009). Academic and business ethical misconduct and cultural values: A cross national comparison. Journal of Academic Ethics, 7, 141-157

Murcia, F. D-R \& Borba, José Alonso (2005). Um estudo das fraudes contábeis sob duas óticas: jornais econômicos versus periódicos acadêmicos no período de 2001-2004. Revista de Contabilidade do Mestrado em Ciências Contábeis da UERJ, 2(10), 99-114.

Nonis, S., \& Swift, C. (2001). An examination of the relationship between academic dishonesty and workplace dishonesty: A multicampus investigation. Journal of Education for Business, 77(2), 69-77

Rakovski, C., \& Levy, E. (2007). Academic dishonesty: Perceptions of business students. College Student Journal, 42(2), 466-481

Rumyantseva, N. (2005). Taxonomy of corruption in higher education. Peabody Journal of Education, 80(1), 81-92

Scanlon, P. (2003). Student online plagiarism: How do we respond? College Lecturing, 51(4), 161-165 
Silva, G. A. da et al. (2006). Um Estudo sobre a Prática da Cola entre Universitários. Psicologia: Reflexão \& Crítica, 19(1), 18-24.

Smyth, L., Davis, J., \& Kroncke, C. (2009). Student's perceptions of business ethics: Using cheating as a surrogate for business situations. Journal of Education for Business, 84(4), 229-239

Sutherland-Smith, W. (2010). Retribution, Deterrence and reform: The dilemmas of plagiarism management in universities. Journal of Higher Education Policy and Management. 32(1), 5-16

Walker, J. (2010, February). Measuring plagiarism: researching what students do, not what they say they do. Studies in Higher Education, 35(1), 41-59

Wilkerson, J. (2009). Staff and student perceptions of plagiarism and cheating. International Journal of Teaching and Learning in Higher Education, 20(2), 98-105

Witherspoon, M., Maldonado, N., \& Lacey, C. (2012, January). Undergraduates and academic dishonesty. International Journal of Business and Social Science. 3(1), 76-86

Wood, J., Longenecker, J., McKinney, J., \& Moore, C. (1988). Ethical attitude of students and business professionals: A study of moral reasoning. Journal of Business Ethics, 7, 249-257 
(Página deixada propositadamente em branco) 
A N EXO 1

QUESTIONÁRIOS AOS ALUNOS 
(Página deixada propositadamente em branco) 


\section{INQUÉRITO AOS ALUNOS SOBRE AÉTICA DAS PRÁTICAS ACADÉMICAS NO ENSINO SUPERIOR}

OQUESTIONÁRIO É ANÓNIMO. POR FAVOR, NÃO DEIXE PERGUNTAS SEM RESPOSTA

\section{PARTE}
1.1. Ano de Nascimento:
1.2. Sexo: $M \square$
1.3. Nacionalidade:
Portuguesa $\square$ CPLP $\square$
Outra ........

1.4. Está nesta escola ao abrigo de um programa de mobilidade? $\operatorname{sim} \square$ Nao $\square$

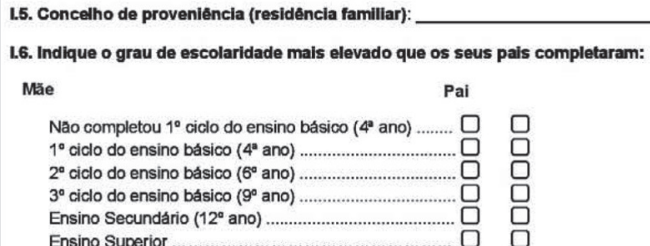

1.7. Como avalla o rendimento do seu agregado famillar?

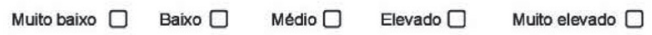

1.8. Durante o seu percurso escolar antes da entrada no ensino superior, frequentou durante mais tempo: Escolas Públicas $\square \quad$ Escolas Privadas $\square$

1.9. Curso que frequenta:

L.10. Fol a sua primeira escolha de curse no concurso de acesso ao ensino superior? $\quad \operatorname{Sim} \square$ Năo $\square$ L.11. Instituiçăo que frequenta:

L12. Fol a sua primeira escolha de instituiçao no concurso de acesso ao ensino superior? $\operatorname{sim} \square$ Năo $\square$ L.13. Situaçào escolar actual:

Aluno regular $\square \quad$ Dirigente associativo $\square \quad$ Trabalhador-estudante $\square \quad$ Outra situaçăo $\square$

L.14. Número de anos de inscriçăo no ensino superior (incluindo o actual):

L.15. Jál frequentou outro curso no ensino superior? Sim $\square$ Năo $\square$

L16. Já reprovou em alguma disciplina neste curso? Sim $\square_{L}$ Não $\square$ Se sim em quantas disciplinas? 1.17. Qual a sua média actual neste curso? (valor aproximado)

1.18. A sua Escola tem um código de boas práticas ou regulamento disciplinar formal?

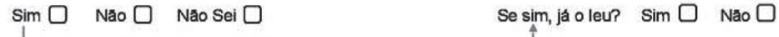

1.19. Na sua opiniáo, com que frequêncla os alunos, no seu curso, cometem algum tipo de fraude académica (por exemplo, copiar numa prova escrita)?

Nunca $\square \quad$ Raramente $\square \quad$ Com alguma frequéncia $\square \quad$ Regularmente $\square$ 
PARTE II

Por favor, analise cada um dos oito casos seguintes e, com base na informaçăo fornecida, assinale a sua opiniăo sobre cada um deles

1. O Joâo pretende terminar a licenciatura este semestre. No entanto, ele ainda năo começou a fazer o trabalho final de uma das últimas disciplinas, o qual deve ser entregue daqui a três dias.

1A. Para resolver o problema, o Joăo comprou o trabalho final ao seu colega Francisco.

1A.1. Na sua opiniâo, 0 Jeâe cometeu fraude académica?

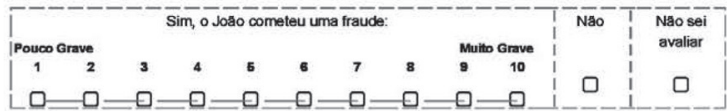

1A.2. Na sua opiniào, ofrancisce cometeu fraude académica?

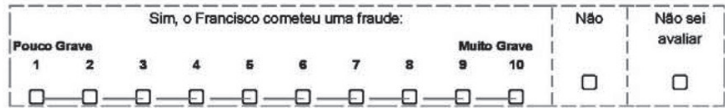

1A.1.2. Se estivesse na situaçăo do Joăo consideraria fazer o mesmo? Sim $\square$ Năo $\square$

1A.2.2. E se estivesse na situaçăo do Erancisce, faria o mesmo?

1A.3. Se tivesse conhecimento desta situaçăo, denunciava-a? Sim $\square$ Năo $\square$

1B. Para resolver o problema, o Joăo pediu a um familiar conhecedor das materias para the fazer o trabalho. 1B.1. Na sua opiniâo, 0 Joăo cometeu fraude académica?

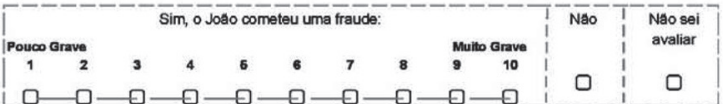

1B.2. Se estivesse na situaçao do Joae, consideraria fazer o mesmo? $\operatorname{sim} \square$ Nao $\square$

1B.3 Se tivesse conhecimento desta situaçăo, denunciava-a? 
2. Durante a realizaçăo de uma prova escrita, a Luisa consultou apontamentos seus năo autorizados.

2.1. Na sua opiniåo, a Lulsa cometeu fraude académica?

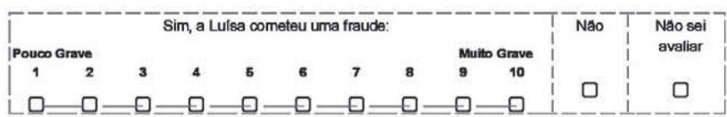

22. Se estivesse na situaçăo da Lul'sa, consideraria fazer o mesmo? Sim $\square$ Năo $\square$

3. O José está com dificuldade em concluir, dentro do prazo definido pelo professor, a pesquisa para um trabalho de uma das disciplinas do seu curso. Para cumprir as exigéncias desse trabalho, o José decidiu inventar resultados de um estudo que ele de facto nâo realizou, apresentando assim um trabalho coerente e completo, embora com dados falsos.

3.1. Na sua opiniâo, o Jesê cometeu fraude académica?

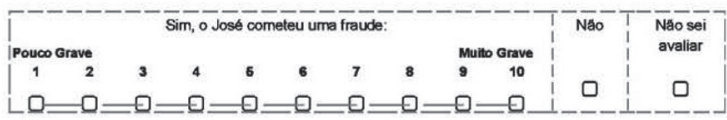

3.2. Se estivesse na situaçăo do José, consideraria fazer o mesmo? $\quad \operatorname{Sim} \square \quad$ Nao $\square$

3.3. Se tivesse conhecimento desta situaçăo, denunciava-a? $\quad \operatorname{Sim} \square \quad$ Năo $\square$

4. A Sara apresentou um trabalho numa disciplina que ela jâ havia apresentado em outra disciplina, tendo apenas que reescrever uma pequena parte do texto original, dada a semelhança dos temas. A Sara nao disse ao seu professor que já havia apresentado o mesmo trabalho noutra disciplina

4.1. Na sua opiniâo, a Sara cometeu fraude académica?

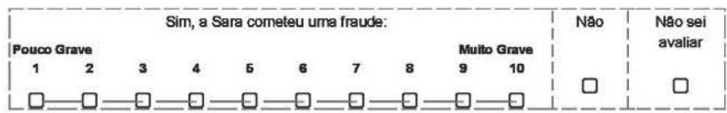

4.2. Se estivesse na situaģăo da Sara, consideraria fazer o mesmo? Sim $\square$ Nao $\square$

4.3. Se tivesse conhecimento desta situaçăo, denunciava-a? $\quad \operatorname{Sim} \square \quad \mathrm{NaO} \square$ 
5. Durante um exame, o António solicitou ao Sérgio que este o ajudasse a resolver a prova. $O$ Sérgio facilitou algumas respostas ao António, sabendo que, se for detectado, os exames de ambos serăo anulados.

5.1. Na sua opiniao, o Antonio cometeu fraude académica?

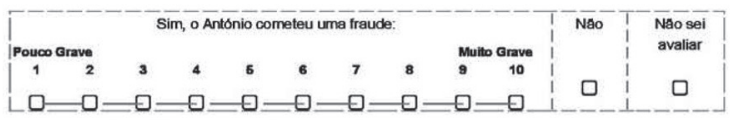

5.2. Na sua opiniâo, o Sérgio cometeu fraude académica?

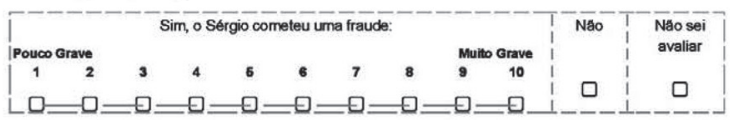

5.1.2. Se estivesse na situaçăo do António, consideraria fazer o mesmo? $\quad \operatorname{Sim} \square$ Năo $\square$

5.2.2. E se estivesse na situaçao do Sêrgio, faria o mesmo?

$\operatorname{sim} \square \quad$ Nao $\square$

5.3. Se observasse esta situaçăo, denunciava-a?

$\operatorname{Sim} \square$ Năo $\square$

6. O Bruno, a Beatriz e o Carlos formaram um grupo para a realizaçăo de um trabalho que culminaria num relatório final para a conclusăo de uma determinada disciplina. O Carlos apenas participou em uma reuniao de grupo e năo colaborou na redaccá do relatório final, tendo explicado aos colegas que estava a ter um semestre muito atarefado O Bruno e a Beatriz elaboraram o relatório sem a sua ajuda. No entanto, a pedido do Carlos, eles incluíram o seu nome no trabalho como co-autor.

6.1. Na sua opinião, o Carlos cometeu fraude académica?

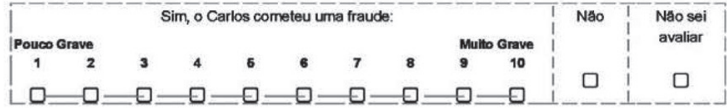

6.2. Na sua opiniáo, o Bruno e a Beatriz cometeram fraude académica?

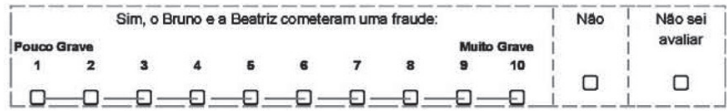

61.2. Se estivesse na situaçăo do Carlos, consideraria fazer o mesmo? $\operatorname{Sim} \square$ Nao $\square$

6.2.2. E se estivesse na situaçâo do Brune e da Beatriz faria o mesmo? $\quad \operatorname{sim} \square \quad$ Năo $\square$

6.3. Se tivesse conhecimento desta situaçăo, denunciava-a? $\quad$ Sim $\square$ Nao $\square$

COMPETE QR ECT Fundaçäo para a Ciência e a Tecnologia 
7. O Ricardo reprovou no ano passado a uma disciplina. Este ano, o professor da disciplina é outro e o Ricardo decidiu pedir emprestado ao Miguel o trabalho que este fizera no ano anterior e que havia sido classificado com boa nota, dizendo-lhe que pretendia usá-lo como se fosse seu. O Miguel emprestou o trabalho e o Ricardo apresentou-o ao novo professor.

7.1. Na sua opiniao, o Ricarde cometeu fraude académica?

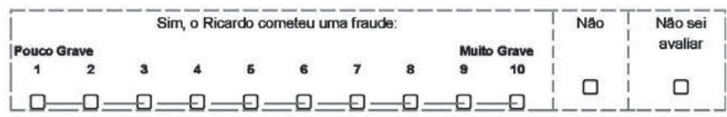

7.2. Na sua opiniao, o Miguel cometeu fraude academica?

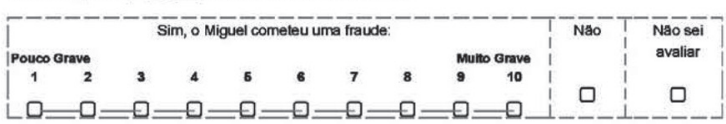

7.1.2. Se estivesse na situaçao do Ricarde consideraria fazer o mesmo? $\quad \operatorname{sim} \square$ Nao $\square$

7.2.2. E se estivesse na situaçăo do Miquel, faria o mesmo? $\quad$ Sim $\square$ Năo $\square$

7.3. Se tivesse conhecimento desta situaçăo, denunciava-a? $\quad$ Sim $\square$ Năo $\square$

8. No âmbito do regime de avaliaçăo de uma disciplina do seu curso, a Joana tem que apresentar um trabalho escrito. Tendo pouco conhecimento sobre o tema, para facilitar o seu trabalho, a Joana recorreu à Internet, apresentando um texto final significativamente copiado de outros textos dispersos online.

8.1. Na sua opinião, a Joana cometeu fraude academica?

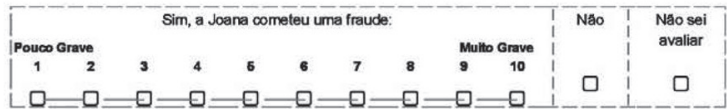

8.2. Se estivesse na situaçăo da Joana, consideraria fazer o mesmo? Sim $\square$ Năo $\square$

8.3. Se tivesse conhecimento desta situaçâo, denunciava-a? $\quad \operatorname{Sim} \square$ Năo $\square$ 
PARTE III

9. Qual a sua opiniáo sobre a fraude académica?

a) Aceitável, desde que nao prejudique ninguém directamente

b) Inaceitável, pois viola os principios que devem regular a boa conduta académica

c) Não tenho opiniăo formada

10. Na sua opiniao, qual a frequencia com que ocorrem, no seu curso, as seguintes práticas?

1. Copiar numa prova escrita pelas respostas de um colega

2. Deixar um colega copiar as suas respostas num exame

3. Comprar trabalhos académicos fora da escola

4. Copiar trabalhos da Internet

5. Copiar partes de trabalhos de outros autores sem os citar

6. Copiar trabalhos de outros colegas

7. Comprar trabalhos a outros colegas

8. Apresentar o mesmo trabalho em várias disciplinas

9. Apresentar trabalhos práticos com dados inventados

10. Assinar um trabalho de grupo sem ter colaborado na realizaçáo do mesmo ...

11. Utilizar materiais năo autorizados na realizaçào de provas escritas (œbulas,

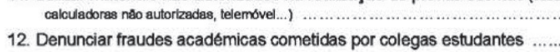

11. Na sua opiniao, qual a importancia que considera terem os seguintes factores como motivos que levam os estudantes a cometerem fraude ao longo do seu percurso académico?

1. Pressão competitiva entre os colegas ......

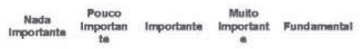

2. Insegurança sobre a capacidade de alcançar o sucesso de outra forma ....

3. Falta de conhecimento sobre qual deve ser a boa conduta académica ........

4. Hábito de uma conduta fraudulenta desde o ensino secundário

5. Falta de debate sobre o assunto nas aulas com os professores

6. Assegurar o sucesso a uma disciplina à qual jâ se reprovou

7. Regularidade da prática fraudulenta entre colegas

8. Passividade dos professores perante situaçסes de fraude

9. Carga de trabalho académico

10. Pouca relevância prática atribuida aos conteudos curriculares

11. Modalidades de avaliaçăo

12. Competencia pedagogica insuficiente dos professores

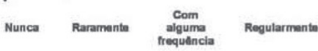

13. Percepçăo de que a pena, no caso de ser descoberta a fraude, é pouco significativa

FCT Fundaçāo para a Ciência e a Tecnologia 
12. Na sua opinião, qual a importancia que considera terem os seguintes factores para evitar/diminuir a fraude académica dos estudantes?

1. Divulgaçăo de um Código de Conduta da escola

Nasa
Importante Importan importante Important Fundamental
to

2. Frequência de disciplinas sobre Ética

3. Agravamento das penas para conduta académica fraudulenta

4. Utilizaçao de mecanismos de vigilancia e de detecçáo electrónica de fraude

5. Impedir telemóveis ligados na sala onde se realizam exames

6. Existéncia de provas orais obrigatórias

7. Diminuiçăo do grau de complexidade das provas

8. Existência de uma relaçăo de proximidade entre professores e alunos .......

9. Envolvimento dos estudantes na divulgação de boas praticas academicas ..

10. Sessóes de esclarecimento promovidas pela escola sobre a boa conduta académica

11. Divulgaçăo no ambiente escolar do nome dos alunos que praticaram fraudes

12. Entrega de uma declaraçăo de autoria/ originalidade dos trabalhos apresentados para avaliaçăo

13. Garantia de anonimato na denúncia de comportamentos fraudulentos dos colegas estudantes

14. Frequencia de programas de apoio psicopedagógico (gestao do tempo, œntrolo

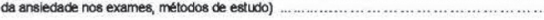

15. Frequencia de programas de desenvolvimento de competencias académicas (aulas de apoio, oficinas de escrita...)

Aceita participar neste estudo de forma não anónima e ser contactado no futuro para responder a novo inquérito no âmbito deste projecto?

$\operatorname{SIM} \square$ se sim, por favor indique o seue-me

NÄ० $\square$

Agradecemos a sua colaboração neste estudo, apoiado pela FCT, que o Centro de Estudos

Sociais da Universidade de Coimbra está a realizar. Caso responda NĂO ou não responda ă

pergunta anterior, toda a informaçăo que nos prestar é anónima e nunca poderá ser

dentificada com a pessoa que a fornece. 
(Página deixada propositadamente em branco) 
A NEXO 2

QUESTIONÁRIOS AOS PROFESSORES 
(Página deixada propositadamente em branco) 


\section{INQUÉRITO AOS DOCENTES SOBRE A ÉTICA DAS PRÁTICAS ACADÉMICAS DOS ESTUDANTES DO ENSINO SUPERIOR}

O QUESTIONÁRIO É ANÓNIMO. POR FAVOR, NĀO DEIXE PERGUNTAS SEM RESPOSTA.

PARTE I
1.1. Ano de Nascimento:
1.2. Sexo: $M \square$
1.3. Nacionalidade:
Portuguesa
$F \square$
Outra

1.4. Concelho de residência:

1.5. Habilitaçăo académica mais elevada:

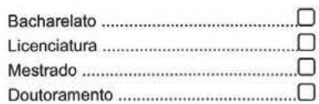

I.6. Instituição onde lecciona (principal):

1.7. Unidade orgânica (Faculdade/Departamento/Escola):

1.8. Categoria profissional

Universidade

Assistente

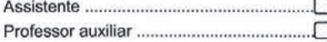

Professor auxiliar com agregação ...............

Professor associado ...................................

Professor associado com agregaçăo ..........

Professor catedrático

\section{Politécnico}

Assistente do $1^{\circ}$ Triénio

Assistente do $2^{\circ}$ Triénio

$\square$

Professor Coordenador ..................................

Professor Coordenador com Agregação .............

Professor Coordenador Principal

1.9. Área cientifica que lecciona (principal):

1.10. Ano em que começou a leccionar no ensino superior:

I.11. A sua Unidade Orgânica tem um código de boas práticas e/ou regulamento disciplinar formal?
Sim $\square \quad$ Năo $\square \quad$ Não Sei $\square$
Se sim, já o leu? Sim $\square$ Não $\square$ -

1.12. Na sua opinião, com que frequência os alunos, na sua Unidade Orgânica, cometem algum tipo de fraude acadèmica (por exemplo, copiar numa prova escrita)?
Nunca $\square$
Raramente $\square$
Com alguma frequência
Regularmente $\square$ 
PARTE II

Por favor, analise cada um dos oito casos seguintes $e_{1}$ com base na informaçăo fornecida, assinale a sua opiniắo sobre cada um deles.

1. O João pretende terminar a licenciatura este semestre. No entanto, ele ainda năo começou a fazer o trabalho fina de uma das últimas disciplinas, o qual deve ser entregue daqui a três dias.

1A. Para resolver o problema, o Joăo comprou o trabalho final ao seu colega Francisco.

1A.1. Na sua opinião, 0 João cometeu uma fraude académica:

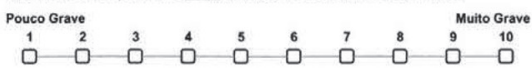

1A.2. Na sua opinião, o Francisco cometeu uma fraude académica:

\begin{tabular}{cccccccccc}
\multicolumn{1}{c}{ Pouco Grave } & & & & & & \multicolumn{3}{c}{ Muito Grave } \\
0 & 0 & 3 & 4 & 5 & 6 & 7 & 8 & 9 & 10
\end{tabular}

1B. Para resolver o problema, o Joăo pediu a um familiar conhecedor das matérias para lhe fazer o trabalho.

1B.1. Na sua opiniăo, 0 Joăo cometeu uma fraude académica:

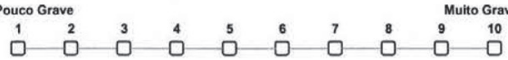

2. Durante a realização de uma prova escrita, a Luisa consultou apontamentos seus não autorizados.

2.1. Na sua opinião, a Luisa cometeu uma fraude académica:
\begin{tabular}{cccccccccc}
1 & & & & \multicolumn{3}{c}{ Muito Grave } \\
0 & 0 & 3 & 4 & 5 & 6 & 7 & 8 & 9 & 10
\end{tabular}

3. O José está com dificuldade em concluir, dentro do prazo definido pelo professor, a pesquisa para um trabalho de uma das disciplinas do seu curso. Para cumprir as exigências desse trabalho, o José decidiu inventar resultados de um estudo que ele de facto não realizou, apresentando assim um trabalho coerente e completo, embora com dados falsos.

3.1. Na sua opiniåo, o José cometeu uma fraude académica:

$$
\begin{array}{cccccccccc}
1 & 2 & 3 & 4 & 5 & 6 & 7 & 8 & 9 & \multicolumn{3}{c}{\text { Muito Grave }} \\
\square & \square & \square^{10} & \square & \square & \square & \square & \square & \square & \square
\end{array}
$$

4. A Sara apresentou um trabalho numa disciplina que ela já havia apresentado em outra disciplina, tendo apenas que reescrever uma pequena parte do texto original, dada a semelhança dos temas. A Sara não disse ao seu professor que já havia apresentado o mesmo trabalho noutra disciplina.

4.1. Na sua opinião, a Sara cometeu uma fraude académica:

$$
\begin{array}{cccccccccc}
\text { Pouco Grave } & & & & \multicolumn{3}{c}{\text { Muito Grave }} \\
\square & \square^{2} & 3 & 4 & 5 & 6 & 7 & 8 & 9 & 10
\end{array}
$$


5. Durante um exame, o António solicitou ao Sérgio que este o ajudasse a resolver a prova. O Sérgio facilitou algumas respostas ao António, sabendo que, se for detectado, os exames de ambos serâo anulados.

5.1. Na sua opinião, o António cometeu uma fraude académica:

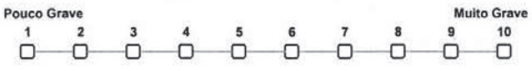

5.2. Na sua opiniāo, o Sérgio cometeu uma fraude académica

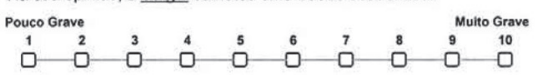

6. O Bruno, a Beatriz e o Carlos formaram um grupo para a realização de um trabalho que culminaria num relatório final para a conclusão de uma determinada disciplina. O Carlos apenas participou em uma reunião de grupo e não colaborou na redaç̧ão do relatório final, tendo explicado aos colegas que estava a ter um semestre muito atarefado. $\mathrm{O}$ Bruno e a Beatriz elaboraram o relatório sem a sua ajuda. No entanto, a pedido do Carlos, eles incluíram o seu nome no trabalho como co-autor.

6.1. Na sua opinião, $\mathrm{o}$ Carlos cometeu uma fraude académica:

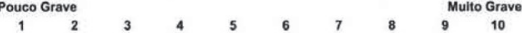

$$
\begin{aligned}
& \begin{array}{cccccccccc}
1 & 2 & 3 & 4 & 5 & 6 & 7 & 8 & 9 & 10
\end{array}
\end{aligned}
$$

6.2. Na sua opiniăo, o Bruno e a Beatriz cometeram uma fraude académica:

$$
\begin{array}{cccccccccc}
\text { Pouco Grave } & & & & & \multicolumn{3}{c}{\text { Muito Grave }} \\
1 & 2 & 3 & 4 & 5 & 6 & 7 & 8 & 9 & 10 \\
\square & \square & \square & \square & \square & \square & \square & \square & \square & \square
\end{array}
$$

7. O Ricardo reprovou no ano passado a uma disciplina. Este ano, o professor da disciplina é outro e o Ricardo decidiu pedir emprestado ao Miguel o trabalho que este fizera no ano anterior e que havia sido classificado com boa nota, dizendo-lhe que pretendia usá-lo como se fosse seu. O Miguel emprestou o trabalho e o Ricardo apresentou-o ao novo professor.

7.1. Na sua opiniăo, o Ricardo cometeu uma fraude académica:

$$
\begin{aligned}
& \text { Pouco Grave }
\end{aligned}
$$

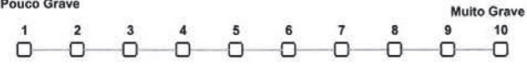

7.2. Na sua opinião, o Miquel cometeu uma fraude académica:

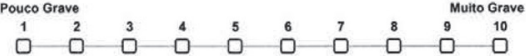

8. No âmbito do regime de avaliaçâo de uma disciplina do seu curso, a Joana tem que apresentar um trabalho escrito. Tendo pouco conhecimento sobre o tema, para facilitar o seu trabalho, a Joana recorreu à Internet, apresentando um Tendo pouco conhecimento sobre o tema, para facilitar o seu trabalho,

8.1. Na sua opinião, a Joana cometeu fraude académica?

$$
\begin{aligned}
& \text { Pouco Grave Multo Grave } \\
& \begin{array}{llllllllll}
1 & 2 & 3 & 4 & 5 & 6 & 7 & 8 & 9 & 10
\end{array}
\end{aligned}
$$


PARTE III

9. Qual a sua opinião sobre a fraude académica cometida por alunos?

a) Aceitável, desde que năo prejudique ninguém directamente

b) Inaceitável, pois viola os princípios que devem regular a boa conduta académica

西

c) Não tenho opiniẫo formada

10. Na sua opiniẫo, qual a frequência com que ocorrem, na sua Unidade Orgânica (Faculdade/Departamento/Escola). entre os alunos, as seguintes práticas?

1. Copiar numa prova escrita pelas respostas de um colega

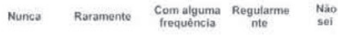

2. Deixar um colega copiar as suas respostas num exame

$\begin{array}{llllll}1 & 2 & 3 & 4 & 0\end{array}$

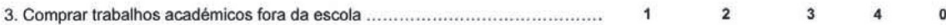

4. Copiar trabalhos da Internet

5. Copiar partes de trabalhos de outros autores sem os citar.

6. Copiar trabalhos de outros colegas

7. Comprar trabalhos a outros colegas

8. Apresentar o mesmo trabalho em várias disciplinas

9. Apresentar trabalhos práticos com dados inventados

10. Assinar um trabalho de grupo sem ter colaborado na realização do mesmo ...

11. Utilizar materiais não autorizados na realização de provas escritas (çaulas.

calculadoras nâo autorizadas, telemóvel.

12. Denunciar fraudes académicas cometidas por colegas estudantes

11. Na sua opiniāo, qual a importância que considera terem os seguintes factores como motivos que levam os estudantes a cometerem fraude ao longo do seu percurso académico?

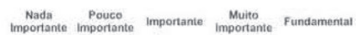

1. Pressão competitiva entre os colegas

2. Insegurança sobre a capacidade de alcançar o sucesso de outra forma ...

3. Falta de conhecimento sobre qual deve ser a boa conduta académica ....

4. Hábito de uma conduta fraudulenta desde o ensino secundário

5. Falta de debate sobre o assunto nas aulas com os professores

6. Assegurar o sucesso a uma disciplina à qual já se reprovou

7. Regularidade da prática fraudulenta entre colegas

8. Passividade dos professores perante situações de fraude

9. Carga de trabalho académico

10. Pouca relevância prática atribuida aos conteúdos curriculares

11. Modalidades de avaliaçāo

12. Competência pedagógica insuficiente dos professores

13. Percepção de que a pena, no caso de ser descoberta a fraude, é pouco significativa

FCT Fundaçāo para a Ciência e a Tecnologia

\begin{tabular}{|c|c|c|c|c|}
\hline $\begin{array}{c}\text { Nada } \\
\text { Importante }\end{array}$ & $\begin{array}{c}\text { Pouco } \\
\text { Importante }\end{array}$ & Impontante & $\begin{array}{c}\text { Muito } \\
\text { Importante }\end{array}$ & Fundamen \\
\hline 1 & 2 & 3 & 4 & 5 \\
\hline 1 & 2 & 3 & 4 & 5 \\
\hline 1 & 2 & 3 & 4 & 5 \\
\hline 1 & 2 & 3 & 4 & 5 \\
\hline 1 & 2 & 3 & 4 & 5 \\
\hline 1 & 2 & 3 & 4 & 5 \\
\hline 1 & 2 & 3 & 4 & 5 \\
\hline 1 & 2 & 3 & 4 & 5 \\
\hline 1 & 2 & 3 & 4 & 5 \\
\hline 1 & 2 & 3 & 4 & 5 \\
\hline 1 & 2 & 3 & 4 & 5 \\
\hline 1 & 2 & 3 & 4 & 5 \\
\hline 1 & 2 & 3 & 4 & 5 \\
\hline
\end{tabular}


12. Na sua opiniăo, qual a importância que considera terem os seguintes factores para evitar/diminuir a fraude académica dos estudantes?

\begin{tabular}{|c|c|c|c|c|c|}
\hline & $\begin{array}{c}\text { Nada } \\
\text { Importante }\end{array}$ & $\begin{array}{l}\text { Pouco } \\
\text { importante }\end{array}$ & Importante & $\begin{array}{c}\text { Mulio } \\
\text { Importante }\end{array}$ & Fundam \\
\hline 1. Divulgaçāo de um Código de Conduta da escola & 1 & 2 & 3 & 4 & 5 \\
\hline 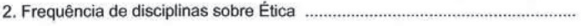 & 1 & 2 & 3 & 4 & 5 \\
\hline 3. Agravamento das penas para conduta académica fraudulenta ....................... & 1 & 2 & 3 & 4 & 5 \\
\hline 4. Utilização de mecanismos de vigilância e de detecção electrónica de fraude & 1 & 2 & 3 & 4 & 5 \\
\hline 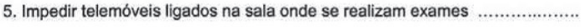 & 1 & 2 & 3 & 4 & 5 \\
\hline 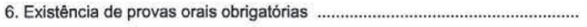 & 1 & 2 & 3 & 4 & 5 \\
\hline 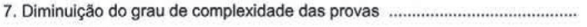 & 1 & 2 & 3 & 4 & 5 \\
\hline 8. Existência de uma relação de proximidade entre professores e alunos ........ & 1 & 2 & 3 & 4 & 5 \\
\hline 9. Envolvimento dos estudantes na divulgação de boas práticas académicas .. & 1 & 2 & 3 & 4 & 5 \\
\hline $\begin{array}{l}\text { 10. Sessōes de esclarecimento promovidas pela escola sobre a boa conduta } \\
\text { académica }\end{array}$ & 1 & 2 & 3 & 4 & 5 \\
\hline $\begin{array}{l}\text { 11. Divulgação no ambiente escolar do nome dos alunos que praticaram } \\
\text { fraudes }\end{array}$ & 1 & 2 & 3 & 4 & 5 \\
\hline $\begin{array}{l}\text { 12. Entrega de uma declaração de autoria/ originalidade dos trabalhos } \\
\text { apresentados para avaliaçẫo }\end{array}$ & 1 & 2 & 3 & 4 & $\mathbf{5}$ \\
\hline $\begin{array}{l}\text { 13. Garantia de anonimato na denúncia de comportamentos fraudulentos dos } \\
\text { colegas estudantes }\end{array}$ & 1 & 2 & 3 & 4 & 5 \\
\hline $\begin{array}{l}\text { 14. Frequência de programas de apoio psicopedagógico (gestăo do tempo, controlo } \\
\text { da ansiedade nos exames, metodos de estudo) }\end{array}$ & 1 & 2 & 3 & 4 & 5 \\
\hline $\begin{array}{l}\text { 15. Frequência de programas de desenvolvimento de competências } \\
\text { académicas (aulas de apoio, oficinas de escrita..) }\end{array}$ & 1 & 2 & 3 & 4 & $\mathbf{5}$ \\
\hline
\end{tabular}

13. Já foi confrontado/a com a seguinte prática de um aluno?

Se SIM, como reagiu?

Se NÄO, como reagiria?

(oodo assinater mais do quo ume opçüo)

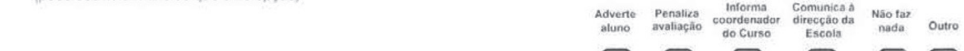

1. Copiar por um colega em exame escrito

2. Utilizar materiais não autorizados durante a realização de exame escrito

3. Apresentar trabalho plagiado

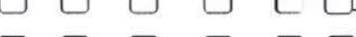

4. Assumir co-autoria de trabalho no qual não participou

5. Apresentar o mesmo trabalho que já havia apresentado em outra disciplina

6. Apresentar trabalho com dados falsos 
14. Na sua opinião, quais os factores que poderão inibir os docentes de denunciar uma fraude académica praticada pelos seus alunos quando confrontados com ela?

\begin{tabular}{|c|c|c|c|c|}
\hline & $\begin{array}{l}\text { Nada } \\
\text { initidot }\end{array}$ & $\begin{array}{l}\text { Pouco } \\
\text { inibidor }\end{array}$ & Inibidor & $\begin{array}{l}\text { Muito } \\
\text { inibididor }\end{array}$ \\
\hline 1. Burocracia processual & 1 & 2 & 3 & 4 \\
\hline 2. Desconhecimento dos procedimentos a adoptar em caso de detecção ........ & 1 & 2 & 3 & 4 \\
\hline 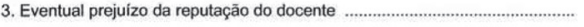 & 1 & 2 & 3 & 4 \\
\hline 4. Contribuição para deterioração da relação com alunos ….......................... & 1 & 2 & 3 & 4 \\
\hline 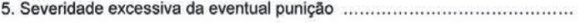 & 1 & 2 & 3 & 4 \\
\hline 6. Percepção de que a denúncia nāo produzirá efeitos punitivos ..................... & 1 & 2 & 3 & 4 \\
\hline 7. Percepção de que a sanção não corrige o comportamento dos alunos ........ & 1 & 2 & 3 & 4 \\
\hline 8. Insuficiente apoio institucional à denúncia & 1 & 2 & 3 & 4 \\
\hline
\end{tabular}

9. Outra. Qual?

15. Na sua prática docente, como considera ser a sua atitude nas seguintes circunstâncias?

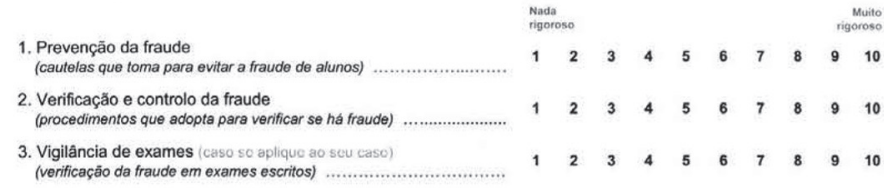

16. Qual o seu grau de satisfação com:
1. A sua funçăo de professor no ensino superior
2. A instituiçăo onde lecciona
$\begin{array}{llllllllll}1 & 2 & 3 & 4 & 5 & 6 & 7 & 8 & 9 & 10\end{array}$
3. A política da sua instituiçāo em relação à fraude académica ....
$\begin{array}{llllllllll}1 & 2 & 3 & 4 & 5 & 6 & 7 & 8 & 9 & 10\end{array}$
$\begin{array}{llllllllll}1 & 2 & 3 & 4 & 5 & 6 & 7 & 8 & 9 & 10\end{array}$

Comentórios (opcional)

Agradecemos a sua colaboração neste estudo, apoiado pela FCT, que o Centro de Estudos Sociais da Universidade de Coimbra está a realizar. Toda a informação que nos prestar é anónima e nunca poderá ser identificada com a pessoa que a fornece. 
A NEXO 3

CURSOS INQUIRIDOS

NA AMOSTRA FinAL DE ALUNOS 
(Página deixada propositadamente em branco) 


\begin{tabular}{|c|c|c|c|}
\hline Cursos Inquiridos na Amostra Final & $\begin{array}{l}\mathrm{N}^{\circ} \\
\text { alunos }\end{array}$ & Cursos Inquiridos na Amostra Final & $\begin{array}{l}\mathrm{N}^{\circ} \\
\text { alunos }\end{array}$ \\
\hline Análises Clínicas e de Saúde Pública & 22 & Engenharia Química & 74 \\
\hline $\begin{array}{l}\text { Anatomia Patológica, Citológica e } \\
\text { Tanatológica }\end{array}$ & 29 & Fisioterapia & 95 \\
\hline Animação Cultural & 29 & Geografia & 55 \\
\hline Antropologia & 25 & Geografia e Planeamento Regional & 13 \\
\hline Arquitetura & 117 & Geologia & 31 \\
\hline Audiovisual e Multimédia & 34 & Gestão & 416 \\
\hline Biologia & 195 & Gestão Bancária & 1 \\
\hline Bioquímica & 43 & Gestão de Empresas & 304 \\
\hline Ciências da Computação & 18 & Gestão de Marketing & 53 \\
\hline Ciências da Comunicação & 83 & Gestão de Recursos Humanos & 15 \\
\hline Ciências Farmacêuticas & 191 & Gestão Turística e Cultural & 22 \\
\hline Comunicação e Design Multimédia & 26 & História & 90 \\
\hline Comunicação Social e Cultural & 43 & Informática & 14 \\
\hline Contabilidade e Administração & 389 & Informática de Gestão & 43 \\
\hline Dança & 33 & Informática e Gestão de Empresas & 28 \\
\hline Design & 95 & Línguas Modernas & 51 \\
\hline $\begin{array}{l}\text { Design de Comunicação e Produção } \\
\text { Audiovisual }\end{array}$ & 26 & Línguas, Literaturas e Culturas & 50 \\
\hline Design e Tecnologia das Artes Gráficas & 34 & Marketing & 83 \\
\hline Desporto & 150 & Marketing e Publicidade & 6 \\
\hline Direito & 164 & Medicina & 420 \\
\hline Economia & 214 & Medicina Dentária & 29 \\
\hline Educação Básica & 288 & Medicina Veterinária & 72 \\
\hline Educação de Infância & 48 & Música, variante de Execução & 22 \\
\hline Educação Física e Desporto & 30 & Psicologia & 162 \\
\hline Educação Social & 111 & Radiologia & 28 \\
\hline Enfermagem & 638 & $\begin{array}{l}\text { Relações Públicas e Comunicação } \\
\text { Empresarial }\end{array}$ & 27 \\
\hline Engenharia Biomédica & 51 & Serviço Social & 132 \\
\hline Engenharia Civil & 250 & Sociologia & 99 \\
\hline Engenharia e Gestão Industrial & 51 & Solicitadoria & 25 \\
\hline $\begin{array}{l}\text { Engenharia Electrónica - Sistemas } \\
\text { Eléctricos de Energia }\end{array}$ & 32 & Solicitadoria e Administração & 92 \\
\hline $\begin{array}{l}\text { Engenharia Electrónica e } \\
\text { Telecomunicações }\end{array}$ & 16 & Som e Imagem & 26 \\
\hline Engenharia Electrotécnica & 58 & Tecnologias e Design de Multimédia & 57 \\
\hline $\begin{array}{l}\text { Engenharia Electrotécnica e dos } \\
\text { Computadores }\end{array}$ & 73 & Tecnologias e Sistemas de Informação & 49 \\
\hline Engenharia Geográfica & 16 & Tradução & 23 \\
\hline Engenharia Industrial e Gestão & 18 & Treino Desportivo & 23 \\
\hline Engenharia Informática & 179 & Turismo & 163 \\
\hline $\begin{array}{l}\text { Engenharia Informática e de } \\
\text { Computadores }\end{array}$ & 140 & não identificados & 7 \\
\hline Engenharia Mecânica & 433 & TOTAL & 7.292 \\
\hline
\end{tabular}


(Página deixada propositadamente em branco) 
A NEXO 4

RESULTADOS ESTATÍSTCOS 
(Página deixada propositadamente em branco) 


\title{
ANEXO 4.1 \\ Gravidade da Fraude Académica
}

\author{
Análise Fatorial Exploratória
}

\begin{tabular}{|c|c|c|c|}
\hline & \multicolumn{3}{|c|}{$\begin{array}{c}\text { Componentes } \\
\text { Principais }^{+}\end{array}$} \\
\hline & $\mathbf{1}$ & 2 & 3 \\
\hline Comprar trabalho a colega & & & 0,88 \\
\hline Vender aos colegas trabalhos realizados por si próprio & & & 0,783 \\
\hline Obter a colaboração de familiar & & & 0,745 \\
\hline Consultar materiais não autorizados numa prova escrita & & 0,705 & \\
\hline Inventar dados num trabalho escrito & 0,594 & & \\
\hline Apresentar o mesmo trabalho em diferentes disciplinas & 0,662 & & \\
\hline Copiar respostas de um colega numa prova escrita & & 0,884 & \\
\hline Fornecer respostas a um colega num exame & & 0,832 & \\
\hline $\begin{array}{l}\text { Não participar em trabalho de grupo, beneficiando da } \\
\text { nota coletiva }\end{array}$ & 0,694 & & \\
\hline $\begin{array}{l}\text { Permitir que um colega partilhe a autoria formal de um } \\
\text { trabalho sem ter participado nele }\end{array}$ & 0,621 & & \\
\hline Plágio autorizado do trabalho de um colega & 0,703 & & \\
\hline $\begin{array}{l}\text { Emprestar a colegas trabalho realizado por si próprio } \\
\text { para que estes apresentem como seu }\end{array}$ & 0,696 & & \\
\hline Copiar trabalho da Internet & & & \\
\hline
\end{tabular}

KMO 0,842; Teste de Esfericidade de Bartlett com p-value 0,000

Retidos 3 fatores com base na sugestão do screeplot (variância explicada de 64,7\%)

+ apenas incluidos pesos superiores a 0,5 
ANEXO 4.2

\section{Indicador de Predisposição para a Fraude (IPF)}

\section{Testes estatísticos}

\begin{tabular}{|c|c|c|c|}
\hline & $\begin{array}{c}\text { IPF Médio } \\
(0-10)\end{array}$ & Teste $t$ & p-value \\
\hline Todos dos alunos (amostra total) & 4,19 & & \\
\hline \multirow[t]{2}{*}{ Alunos que consideram a fraude aceitável } & 5,58 & \multirow{3}{*}{43,638} & \multirow{3}{*}{0,000} \\
\hline & & & \\
\hline Alunos que consideram a fraude inaceitável & 2,95 & & \\
\hline \multirow[t]{2}{*}{ Homens } & 4,66 & \multirow{3}{*}{12,495} & \multirow{3}{*}{0,000} \\
\hline & & & \\
\hline Mulheres & 3,89 & & \\
\hline \multirow[t]{2}{*}{$\begin{array}{l}\text { Alunos cujo percurso pré-universitário foi feito em } \\
\text { Escolas Privadas }\end{array}$} & 4,44 & \multirow{3}{*}{2,769} & \multirow{3}{*}{0,000} \\
\hline & & & \\
\hline $\begin{array}{l}\text { Alunos cujo percurso pré-universitário foi feito em } \\
\text { Escolas Públicas }\end{array}$ & 4,17 & & \\
\hline $\begin{array}{l}\text { Alunos cujo curso que frequentam não é primeira } \\
\text { escolha }\end{array}$ & 4,39 & \multirow{2}{*}{3,415} & \multirow{2}{*}{0,000} \\
\hline $\begin{array}{l}\text { Alunos cujo curso que frequentam é primeira } \\
\text { escolha }\end{array}$ & 4,14 & & \\
\hline Alunos que já reprovaram & 4,45 & \multirow[b]{2}{*}{12,143} & \multirow[b]{2}{*}{0,000} \\
\hline Alunos que ainda não reprovaram & 3,73 & & \\
\hline $\begin{array}{l}\text { Alunos que afirmam não existir código de boas } \\
\text { práticas ou regulamento }\end{array}$ & 4,59 & \multirow[b]{2}{*}{2,234} & \multirow[b]{2}{*}{0,026} \\
\hline $\begin{array}{l}\text { Alunos que afirmam existir código de boas práticas } \\
\text { ou regulamento }\end{array}$ & 4,04 & & \\
\hline $\begin{array}{l}\text { Alunos que ainda não leram o código de boas } \\
\text { práticas ou regulamento da sua escola }\end{array}$ & 4,27 & \multirow{2}{*}{7,471} & \multirow{2}{*}{0,000} \\
\hline $\begin{array}{l}\text { Alunos que afirmam ter lido o código de boas } \\
\text { práticas ou regulamento da sua escola }\end{array}$ & 3,53 & & \\
\hline
\end{tabular}

\begin{tabular}{|c|c|c|}
\hline & Outros Testes & p-value \\
\hline Alunos com menor média & $\begin{array}{l}\text { correlação spearman } \\
-0,149\end{array}$ & 0,000 \\
\hline Alunos cujos pais têm maior grau de escolaridade & $\begin{array}{l}\text { F 7,848 para pai; } \\
\text { F 8,915 para mãe }\end{array}$ & 0,000 \\
\hline $\begin{array}{l}\text { Alunos cujos agregados familiares têm rendimentos } \\
\text { mais elevados }\end{array}$ & F 5,707 & 0,000 \\
\hline Alunos dirigentes associativos & F. 12,312 & 0,000 \\
\hline Alunos com mais inscrições no ensino superior & $\begin{array}{c}\text { correlação spearman } \\
0,058\end{array}$ & 0,000 \\
\hline $\begin{array}{l}\text { Alunos que percecionam maior frequência de fraude no } \\
\text { seu curso }\end{array}$ & $\begin{array}{c}\text { correlação spearman } \\
0,145 \\
\text { F } 53,143\end{array}$ & $\begin{array}{l}0,000 \\
0,000\end{array}$ \\
\hline
\end{tabular}


ANEXO 4.3

\title{
Indicador de Predisposição para a Denúncia (IPD)
}

\author{
Testes estatísticos
}

\begin{tabular}{lccc} 
& $\begin{array}{c}\text { IPD Médio } \\
(\mathbf{0 - 1 0})\end{array}$ & Teste $t$ & p-value \\
\hline Todos dos alunos (amostra total) & $\mathbf{0 , 5 8}$ & \\
\hline $\begin{array}{l}\text { Alunos que já leram o código de boas práticas ou } \\
\text { regulamento da sua escola }\end{array}$ & 0,93 & & 0,000 \\
$\begin{array}{l}\text { Alunos que ainda não leram o código de boas } \\
\text { práticas ou regulamento da sua escola }\end{array}$ & 0,416 & \\
\hline
\end{tabular}

\begin{tabular}{lcc} 
& Outros Testes & p-value \\
\hline Alunos com maior média & $\begin{array}{c}\text { correlação spearman } \\
0,07\end{array}$ & 0,000 \\
\hline Alunos que reprovaram a menos disciplinas & $\begin{array}{c}\text { correlação spearman } \\
-0,055\end{array}$ & 0,000 \\
\hline Alunos com menos inscrições no ensino superior & correlação spearman & 0,039 \\
\hline Alunos cuja mãe tem menos grau de escolaridade & F 5,417 & 0,001 \\
\hline
\end{tabular}




\section{ANEXO 4.4 \\ Motivos para cometer Fraude \\ (opinião dos alunos)}

Correlação com IPF e IPD

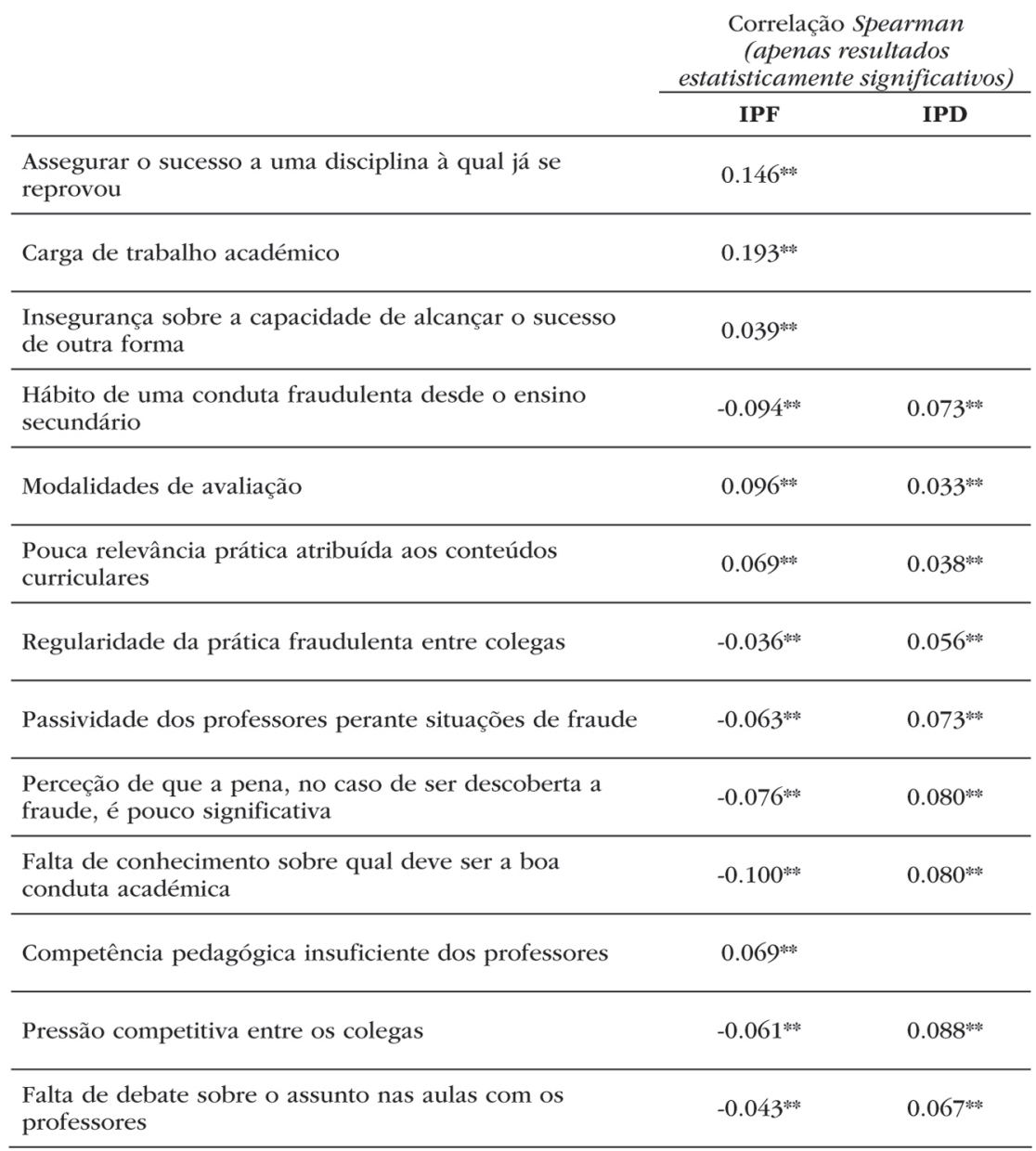

* significativo ao nivel de 5\%

* significativo ao nível de 1\% 


\section{ANEXO 4.5 \\ Motivos para cometer Fraude \\ (opinião dos alunos)}

\section{Análise Fatorial Exploratória}

\begin{tabular}{|c|c|c|c|c|}
\hline & \multicolumn{4}{|c|}{ Componentes Principais $^{+}$} \\
\hline & $\mathbf{1}$ & 2 & 3 & 4 \\
\hline Pressão competitiva entre os colegas & & & 0,6 & \\
\hline $\begin{array}{l}\text { Insegurança sobre a capacidade de alcançar o sucesso } \\
\text { de outra forma }\end{array}$ & & & 0,778 & \\
\hline $\begin{array}{l}\text { Falta de conhecimento sobre qual deve ser a boa } \\
\text { conduta académica }\end{array}$ & & & & 0,705 \\
\hline $\begin{array}{l}\text { Hábito de uma conduta fraudulenta desde o ensino } \\
\text { secundário }\end{array}$ & & 0,766 & & \\
\hline $\begin{array}{l}\text { Falta de debate sobre o assunto nas aulas com os } \\
\text { professores }\end{array}$ & & & & 0,641 \\
\hline $\begin{array}{l}\text { Assegurar o sucesso a uma disciplina à qual já se } \\
\text { reprovou }\end{array}$ & & & 0,584 & \\
\hline Regularidade da prática fraudulenta entre colegas & & 0,795 & & \\
\hline Passividade dos professores perante situações de fraude & & 0,661 & & \\
\hline Carga de trabalho académico & 0,628 & & & \\
\hline $\begin{array}{l}\text { Pouca relevância prática atribuída aos conteúdos } \\
\text { curriculares }\end{array}$ & 0,692 & & & \\
\hline Modalidades de avaliação & 0,773 & & & \\
\hline Competência pedagógica insuficiente dos professores & 0,659 & & & \\
\hline $\begin{array}{l}\text { Perceção de que a pena, no caso de ser descoberta a } \\
\text { fraude, é pouco significativa }\end{array}$ & & 0,524 & & \\
\hline
\end{tabular}

KMO 0,798; Teste de Esfericidade de Bartlett com p-value 0,000

Retidos 4 fatores com base no eigenvalue superior a 1 (variância explicada de $58,42 \%$ )

+ apenas incluidos pesos superiores a 0,5 


\section{ANEXO 4.6 \\ Inibidores da Fraude \\ (opinião dos alunos)}

Correlação com IPF e IPD

\begin{tabular}{|c|c|c|}
\hline & \multicolumn{2}{|c|}{$\begin{array}{c}\text { Correlação Spearman } \\
\text { (apenas resultados } \\
\text { estatisticamente significativos) }\end{array}$} \\
\hline & IPF & IPD \\
\hline Agravamento das penas para conduta académica fraudulenta & $-0.130 * *$ & $0.090^{* *}$ \\
\hline $\begin{array}{l}\text { Existência de uma relação de proximidade entre professores } \\
\text { e alunos }\end{array}$ & $0.054^{* *}$ & $0.027^{*}$ \\
\hline Impedir telemóveis ligados na sala onde se realizam exames & $-0.115^{* *}$ & $0.055^{* *}$ \\
\hline $\begin{array}{l}\text { Utilização de mecanismos de vigilância e de deteção } \\
\text { eletrónica de fraude }\end{array}$ & $-0.089 * *$ & $0.070 *$ \\
\hline $\begin{array}{l}\text { Envolvimento dos estudantes na divulgação de boas práticas } \\
\text { académicas }\end{array}$ & $-0.131 * *$ & $0.096^{* *}$ \\
\hline $\begin{array}{l}\text { Frequência de programas de desenvolvimento de } \\
\text { competências académicas }\end{array}$ & $-0.048 \%$ & $0.059 *$ \\
\hline Frequência de programas de apoio psicopedagógico & $-0.070^{* *}$ & $0.064^{* *}$ \\
\hline $\begin{array}{l}\text { Garantia de anonimato na denúncia de comportamentos } \\
\text { fraudulentos dos colegas }\end{array}$ & $-0.118^{* *}$ & $0.130 *$ \\
\hline Divulgação de um Código de Conduta da escola & $-0.201^{\omega *}$ & $0.098^{* *}$ \\
\hline $\begin{array}{l}\text { Entrega de uma declaração de autoria/originalidade dos } \\
\text { trabalhos apresentados para avaliação }\end{array}$ & $-0.128^{* *}$ & $0.100^{* * *}$ \\
\hline $\begin{array}{l}\text { Sessões de esclarecimento promovidas pela escola sobre a } \\
\text { boa conduta académica }\end{array}$ & $-0.166^{* *}$ & $0.100^{* * *}$ \\
\hline $\begin{array}{l}\text { Divulgação no ambiente escolar do nome dos alunos que } \\
\text { praticaram fraudes }\end{array}$ & $-0.087^{* * *}$ & $0.093^{* *}$ \\
\hline Frequência de disciplinas sobre Ética & $-0.186^{* *}$ & $0.091^{*} *$ \\
\hline Existência de provas orais obrigatórias & $0.028^{*}$ & $0.042^{* *}$ \\
\hline
\end{tabular}

"significativo ao nivel de 5\%

** significativo ao nível de 1\% 


\section{ANEXO 4.7 \\ Inibidores da Fraude \\ (opinião dos alunos)}

\section{Análise Fatorial Exploratória}

\begin{tabular}{|c|c|c|c|}
\hline & \multicolumn{3}{|c|}{ Componentes Principais $^{+}$} \\
\hline & $\mathbf{1}$ & 2 & 3 \\
\hline Divulgação de um Código de Conduta da escola & & 0,813 & \\
\hline Frequência de disciplinas sobre Ética & & 0,759 & \\
\hline Agravamento das penas para conduta académica fraudulenta & 0,722 & & \\
\hline $\begin{array}{l}\text { Utilização de mecanismos de vigilância e de deteção eletrónica } \\
\text { de fraude }\end{array}$ & 0,807 & & \\
\hline Impedir telemóveis ligados na sala onde se realizam exames & 0,65 & & \\
\hline Existência de provas orais obrigatórias & 0,511 & & \\
\hline $\begin{array}{l}\text { Existência de uma relação de proximidade entre professores e } \\
\text { alunos }\end{array}$ & & & \\
\hline $\begin{array}{l}\text { Envolvimento dos estudantes na divulgação de boas práticas } \\
\text { académicas }\end{array}$ & & 0,719 & \\
\hline $\begin{array}{l}\text { Sessões de esclarecimento promovidas pela escola sobre a boa } \\
\text { conduta académica }\end{array}$ & & 0,774 & \\
\hline $\begin{array}{l}\text { Divulgação no ambiente escolar do nome dos alunos que } \\
\text { praticaram fraudes }\end{array}$ & 0,649 & & \\
\hline $\begin{array}{l}\text { Entrega de uma declaração de autoria/originalidade dos } \\
\text { trabalhos apresentados para avaliação }\end{array}$ & 0,573 & & \\
\hline $\begin{array}{l}\text { Garantia de anonimato na denúncia de comportamentos } \\
\text { fraudulentos dos colegas }\end{array}$ & 0,519 & & \\
\hline Frequência de programas de apoio psicopedagógico & & & 0,848 \\
\hline $\begin{array}{l}\text { Frequência de programas de desenvolvimento de competências } \\
\text { académicas }\end{array}$ & & & 0,855 \\
\hline
\end{tabular}

KMO 0,838 Teste de Esfericidade de Bartlett com p-value 0,000

Retidos 3 fatores com base na sugestão dos eigenvalues superiores a 1 (variância explicada de 56,22\%)

+ apenas incluídos pesos superiores a 0,5 


\section{ANEXO 4.8 \\ Indicador de Sensibilidade à Fraude \\ (ISF)}

\section{Testes estatísticos}

\begin{tabular}{lccc} 
& $\begin{array}{c}\text { ISF Médio } \\
(\mathbf{1 - 1 0})\end{array}$ & Teste $t$ & p-value \\
\hline Todos dos docentes & $\mathbf{8 , 3 7}$ & & \\
\hline Docentes que consideram a fraude inaceitável & 8,41 & 3,68 & 0,002 \\
Docentes que consideram a fraude aceitável & 6,76 & 7,348 & 0,000 \\
\hline $\begin{array}{l}\text { Mulheres } \\
\text { Homens }\end{array}$ & 8,55 & & \\
\hline $\begin{array}{l}\text { Docentes que, reconhecendo existir regulamento } \\
\text { disciplinar, já o leram }\end{array}$ & 8,21 & 8,49 & 3,163 \\
$\begin{array}{l}\text { Docentes que, reconhecendo existir regulamento } \\
\text { disciplinar, ainda não o leram }\end{array}$ & 8,12 & & 0,002 \\
\hline
\end{tabular}

\section{Outros Testes}

p-value

\begin{tabular}{|c|c|c|}
\hline & Outros Testes & p-value \\
\hline Docentes mais velhos & $\begin{array}{l}\text { correlação spearman } \\
-0,094\end{array}$ & 0,000 \\
\hline Docentes com mais anos de experiência académica & $\begin{array}{l}\text { correlação spearman } \\
0,0858\end{array}$ & 0,000 \\
\hline Docentes com mestrado ou doutoramento & F. 5,191 & 0,006 \\
\hline $\begin{array}{l}\text { Docentes que sabem se existe ou não código de boas } \\
\text { práticas na sua instituição }\end{array}$ & F 12,548 & 0,000 \\
\hline
\end{tabular}




\section{ANEXO 4.9 \\ Indicador de Intolerância à Fraude \\ (IIF)}

\section{Testes estatísticos}

\begin{tabular}{|c|c|c|c|}
\hline & $\begin{array}{l}\text { IIF Médio } \\
(1-10)\end{array}$ & Teste $t$ & $\begin{array}{c}p- \\
\text { value }\end{array}$ \\
\hline Todos dos docentes & 8,18 & & \\
\hline \multirow{2}{*}{ Mulheres } & 8,34 & & \\
\hline & & 5,708 & 0,000 \\
\hline Homens & 8,03 & & \\
\hline \multirow[t]{2}{*}{ Docentes do setor privado } & 8,45 & & \\
\hline & & 2,276 & 0,013 \\
\hline Docentes do setor público & 8,16 & & \\
\hline \multirow[t]{2}{*}{ Docentes do ensino politécnico } & 8,27 & & \\
\hline & & 2,997 & 0,003 \\
\hline Docentes do ensino público & 8,10 & & \\
\hline \multirow[t]{2}{*}{$\begin{array}{l}\text { Docentes que reconhecem existir regulamento } \\
\text { disciplinar na sua instituição }\end{array}$} & 8,43 & & \\
\hline & & 4,758 & 0,000 \\
\hline $\begin{array}{l}\text { Docentes que afirmam não existir regulamento } \\
\text { disciplinar na sua instituição }\end{array}$ & 8,11 & & \\
\hline \multirow[t]{2}{*}{$\begin{array}{l}\text { Docentes que, reconhecendo existir regulamento } \\
\text { disciplinar, já o leram }\end{array}$} & 8,48 & & \\
\hline & & 3,321 & 0,001 \\
\hline $\begin{array}{l}\text { Docentes que, reconhecendo existir regulamento } \\
\text { disciplinar, ainda não o leram }\end{array}$ & 8,04 & & \\
\hline \multirow[t]{2}{*}{ Docentes do setor privado } & 8,45 & & \\
\hline & & 2,276 & 0,013 \\
\hline Docentes do setor público & 8,16 & & \\
\hline
\end{tabular}




\section{ANEXO 4.10 \\ Motivos para cometer Fraude \\ (opinião dos docentes)}

\section{Correlação com ISF, IIF e ISA}

\begin{tabular}{|c|c|c|c|}
\hline & \multicolumn{3}{|c|}{$\begin{array}{c}\text { Correlação Spearman } \\
\text { (apenas resultados estatisticamente } \\
\text { significativos) }\end{array}$} \\
\hline & ISF & IIF & ISA \\
\hline $\begin{array}{l}\text { Hábito de uma conduta fraudulenta desde o ensino } \\
\text { secundário }\end{array}$ & $0.058^{* * *}$ & $0.055^{*}$ & $-0.087^{* * *}$ \\
\hline
\end{tabular}

Assegurar o sucesso a uma disciplina à qual já se reprovou

Perceção de que a pena, no caso de ser descoberta a
fraude, é pouco significativa

$-0.100^{* * *}$

\begin{tabular}{lll}
\hline Regularidade da prática fraudulenta entre colegas & $0.043^{*}$ & $-0.130^{* * *}$ \\
\hline
\end{tabular}

Passividade dos professores perante situações de fraude

Insegurança sobre a capacidade de alcançar o sucesso de outra forma

$0.048^{*}$

Falta de conhecimento sobre qual deve ser a boa conduta académica

$0.076^{\mathrm{km}}$

Pouca relevância prática atribuída aos conteúdos curriculares

\begin{tabular}{lll}
\hline $\begin{array}{l}\text { Falta de debate sobre o assunto nas aulas com os } \\
\text { professores }\end{array}$ & $0.105^{* *}$ \\
\hline Carga de trabalho académico & $-0.050^{*}$ & $-0.042^{*}$
\end{tabular}

\begin{tabular}{|c|c|c|}
\hline \multicolumn{3}{|l|}{ Modalidades de avaliação } \\
\hline Pressão competitiva entre os colegas & $0.047^{*}$ & $0.081^{\text {wor }}$ \\
\hline
\end{tabular}

Competência pedagógica insuficiente dos professores

\footnotetext{
"significativo ao nivel de 5\%

*significativo ao nivel de $1 \%$
} 


\section{ANEXO 4.11 \\ Motivos para cometer Fraude \\ (opinião dos docentes)}

Análise Fatorial Exploratória

\begin{tabular}{|c|c|c|c|c|}
\hline & \multicolumn{4}{|c|}{ Componentes Principais $^{+}$} \\
\hline & $\mathbf{1}$ & 2 & 3 & 4 \\
\hline Pressão competitiva entre os colegas & & & 0,611 & \\
\hline $\begin{array}{l}\text { Insegurança sobre a capacidade de alcançar o sucesso } \\
\text { de outra forma }\end{array}$ & & & 0,774 & \\
\hline $\begin{array}{l}\text { Falta de conhecimento sobre qual deve ser a boa } \\
\text { conduta académica }\end{array}$ & & & & 0,844 \\
\hline $\begin{array}{l}\text { Hábito de uma conduta fraudulenta desde o ensino } \\
\text { secundário }\end{array}$ & & 0,593 & & \\
\hline $\begin{array}{l}\text { Falta de debate sobre o assunto nas aulas com os } \\
\text { professores }\end{array}$ & & & & 0,736 \\
\hline $\begin{array}{l}\text { Assegurar o sucesso a uma disciplina à qual já se } \\
\text { reprovou }\end{array}$ & & & 0,596 & \\
\hline Regularidade da prática fraudulenta entre colegas & & 0,735 & & \\
\hline Passividade dos professores perante situações de fraude & & 0,595 & & \\
\hline Carga de trabalho académico & 0,561 & & & \\
\hline $\begin{array}{l}\text { Pouca relevância prática atribuída aos conteúdos } \\
\text { curriculares }\end{array}$ & 0,671 & & & \\
\hline Modalidades de avaliação & 0,781 & & & \\
\hline Competência pedagógica insuficiente dos professores & 0,669 & & & \\
\hline $\begin{array}{l}\text { Perceção de que a pena, no caso de ser descoberta a } \\
\text { fraude, é pouco significativa }\end{array}$ & & 0,614 & & \\
\hline
\end{tabular}

KMO 0,783; Teste de Esfericidade de Bartlett com p-value 0,000

Retidos 4 fatores com base no eigenvalue superior a 1 (variância explicada de $54,96 \%$ )

+ apenas incluidos pesos superiores a 0,5 


\section{ANEXO 4.12 \\ Inibidores da Fraude \\ (opinião dos docentes)}

\section{Correlação com ISF, IIF e ISA}

\begin{tabular}{|c|c|c|c|}
\hline & \multicolumn{3}{|c|}{$\begin{array}{c}\text { Correlação Spearman } \\
\text { (apenas resultados estatisticamente } \\
\text { significativos) }\end{array}$} \\
\hline & ISF & IIF & ISA \\
\hline $\begin{array}{l}\text { Agravamento das penas para conduta académica } \\
\text { fraudulenta }\end{array}$ & $0.127^{* w}$ & $0.161^{* \omega *}$ & \\
\hline $\begin{array}{l}\text { Envolvimento dos estudantes na divulgação de boas } \\
\text { práticas académicas }\end{array}$ & $0.153^{* *}$ & $0.077^{* * *}$ & $0.095^{* * *}$ \\
\hline Divulgação de um Código de Conduta da escola & $0.116 * *$ & $0.048^{*}$ & \\
\hline $\begin{array}{l}\text { Impedir telemóveis ligados na sala onde se realizam } \\
\text { exames }\end{array}$ & $0.110^{* *}$ & $0.158^{* w k}$ & $0.054^{*}$ \\
\hline $\begin{array}{l}\text { Sessões de esclarecimento promovidas pela escola } \\
\text { sobre a boa conduta académica }\end{array}$ & $0.184^{* *}$ & $0.112^{*}$ & $0.101^{\text {*** }}$ \\
\hline $\begin{array}{l}\text { Utilização de mecanismos de vigilância e de detecção } \\
\text { electrónica de fraude }\end{array}$ & $0.089 * *$ & $0.082 *$ & \\
\hline $\begin{array}{l}\text { Frequência de programas de desenvolvimento de } \\
\text { competências académicas }\end{array}$ & $0.113^{* * *}$ & 0.089 粆 & $0.127^{\text {*** }}$ \\
\hline $\begin{array}{l}\text { Existência de uma relação de proximidade entre } \\
\text { professores e alunos }\end{array}$ & & & $0.129^{\text {wok }}$ \\
\hline Frequência de programas de apoio psicopedagógico & $0.112 \%$ & $0.072 \%$ & $0.117^{\text {*** }}$ \\
\hline Existência de provas orais obrigatórias & $0.055^{* *}$ & $0.066 * *$ & \\
\hline $\begin{array}{l}\text { Entrega de uma declaração de autoria/ originalidade } \\
\text { dos trabalhos apresentados para avaliação }\end{array}$ & $0.109^{* * *}$ & $0.099^{\text {*ok }}$ & $0.065^{\text {top }}$ \\
\hline Frequência de disciplinas sobre Ética & $0.148^{* w}$ & 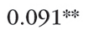 & $0.111^{* \omega *}$ \\
\hline \multicolumn{4}{|l|}{$\begin{array}{l}\text { Divulgação no ambiente escolar do nome dos alunos } \\
\text { que praticaram fraudes }\end{array}$} \\
\hline $\begin{array}{l}\text { Garantia de anonimato na denúncia de } \\
\text { comportamentos fraudulentos dos colegas estudantes }\end{array}$ & $0.050^{*}$ & $0.055^{\text {*k }}$ & \\
\hline
\end{tabular}

\footnotetext{
"significativo ao nivel de 5\%

*significativo ao nivel de $1 \%$
} 


\section{ANEXO 4.13 \\ Inibidores da Fraude \\ (opinião dos docentes)}

\section{Análise Fatorial Exploratória}

\begin{tabular}{|c|c|c|c|}
\hline & \multicolumn{3}{|c|}{ Componentes Principais ${ }^{+}$} \\
\hline & 1 & 2 & 3 \\
\hline Divulgação de um Código de Conduta da escola & 0,774 & & \\
\hline Frequência de disciplinas sobre Ética & 0,601 & & \\
\hline Agravamento das penas para conduta académica fraudulenta & & 0,625 & \\
\hline $\begin{array}{l}\text { Utilização de mecanismos de vigilância e de deteção eletrónica } \\
\text { de fraude }\end{array}$ & & 0,663 & \\
\hline Impedir telemóveis ligados na sala onde se realizam exames & & 0,597 & \\
\hline Existência de provas orais obrigatórias & & & \\
\hline $\begin{array}{l}\text { Existência de uma relação de proximidade entre professores e } \\
\text { alunos }\end{array}$ & & & \\
\hline $\begin{array}{l}\text { Envolvimento dos estudantes na divulgação de boas práticas } \\
\text { académicas }\end{array}$ & 0,734 & & \\
\hline $\begin{array}{l}\text { Sessões de esclarecimento promovidas pela escola sobre a boa } \\
\text { conduta académica }\end{array}$ & 0,788 & & \\
\hline $\begin{array}{l}\text { Divulgação no ambiente escolar do nome dos alunos que } \\
\text { praticaram fraudes }\end{array}$ & & 0,617 & \\
\hline $\begin{array}{l}\text { Entrega de uma declaração de autoria/originalidade dos } \\
\text { trabalhos apresentados para avaliação }\end{array}$ & & & \\
\hline $\begin{array}{l}\text { Garantia de anonimato na denúncia de comportamentos } \\
\text { fraudulentos dos colegas }\end{array}$ & & 0,533 & \\
\hline Frequência de programas de apoio psicopedagógico & & & 0,809 \\
\hline $\begin{array}{l}\text { Frequência de programas de desenvolvimento de competências } \\
\text { académicas }\end{array}$ & & & 0,811 \\
\hline
\end{tabular}

KMO 0,782 Teste de Esfericidade de Bartlett com p-value 0,000

Retidos 3 fatores com base na sugestão do screeplot e dos eigenvalues superiores a 1 (variância explicada de $47,94 \%$, + apenas incluídos pesos superiores a 0,5 


\section{ANEXO 4.14 \\ Inibidores da Denúncia \\ (opinião dos docentes)}

\section{Análise Fatorial Exploratória}

\begin{tabular}{|l|c|c|}
\cline { 2 - 3 } \multicolumn{1}{l|}{} & \multicolumn{1}{c|}{ Componentes Principais $^{+}$} \\
\cline { 2 - 3 } Burocracia processual & $\mathbf{1}$ & $\mathbf{2}$ \\
$\begin{array}{l}\text { Desconhecimento dos procedimentos a adotar em caso de } \\
\text { deteção }\end{array}$ & 0,585 & 0,772 \\
Eventual prejuízo da reputação do docente & 0,838 \\
Contribuição para deterioração da relação com alunos & \\
Severidade excessiva da eventual punição & 0,723 \\
Perceção de que a denúncia não produzirá efeitos punitivos & 0,843 & \\
$\begin{array}{l}\text { Perceção de que a sanção não corrige o comportamento dos } \\
\text { alunos }\end{array}$ & 0,670 & \\
Insuficiente apoio institucional à denúncia & 0,793 & \\
\hline
\end{tabular}

KMO 0,781 Teste de Esfericidade de Bartlett com p-value 0,000

Retidos 3 fatores com base na sugestão dos eigenvalues superiores a 1 (variância explicada de 56,83\%)

+ apenas incluídos pesos superiores a 0,5 
(Página deixada propositadamente em branco) 
Série Investigação

Imprensa da Universidade de Coimbra

Coimbra University Press

2015

OBRA PUBLICADA

COM A COORDENAÇÃO

CIENTÍFICA

$\boldsymbol{Q}_{\text {ces }}=$

FCT

Fundação para a Ciência e a Tecnologia

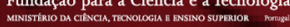

\section{COMPETE}

QR QLaDRo

ESTRATEGICO

NACIONAL

NACRIOANA20022013 